\title{
Coal-Fired Power Plants, Greenhouse Gases, and State Statutory Substantial Endangerment Provisions: Climate Change Comes to Kansas
}

\author{
Robert L. Glicksman ${ }^{*}$
}

We also need a moratorium on the construction of any new generating facility that burns coal without the capacity to safely trap and store carbon dioxide. ${ }^{1}$

U.S. coal deposits contain more energy than all the world's oil reserves combined. Given this, removing coal from our energy-supply equation is irresponsible. ${ }^{2}$

\section{INTRODUCTION}

On October 17, 2007, the Bureau of Air and Radiation, Air Permitting Section of the Kansas Department of Health and Environment ("KDHE") recommended the issuance of an Air Quality Construction Permit under state air quality legislation to the Sunflower Electric Power Corporation ("Sunflower"). The permit would have allowed Sunflower to construct two new 700 megawatt coal-fired steam generating units and associated ancillary equipment at the site of its existing generating station located in Holcomb, Kansas. ${ }^{3}$ The very next day, Roderick

\footnotetext{
Robert W. Wagstaff Professor of Law, University of Kansas. My thanks go to Richard E. Levy, Christopher R. Drahozal, and Raj Bhala for their valuable analytical input, and to Christopher Steadham, Faculty Services Librarian at the University of Kansas School of Law, for his valuable research assistance.

1. Al Gore, The Nobel Lecture given by the Nobel Peace Prize Laureate 2007 (Dec. 10, 2007) (transcript available at http://nobelpeaceprize.org/eng_lect_2007c.html).

2. Senator Sam Brownback, Plant Denial Not in State's Best Interest, Wichita Eagle, Nov. 11,2007 , at 11A. Senator Brownback, one of Kansas's U.S. Senators, added that KDHE's denial of the Sunflower permit applications is "not supported by the laws and statutes of Kansas, [and] is not in the best interests of Kansas nor [sic] the environment." Id.

3. Bureau of Air Radiation, Air Permitting Section, Kan. Dep't of Health \& EnV'T, Responsiveness Summary, Sunflower Electric Power Corp., Holcomb EXPansion, Air Quality CONSTRUCTION PERMit APPLiCATION (Oct. 17, 2007), available at http://www. kdheks.gov/download/KDHE_Response_to_Comments_10.17.07.pdf [hereinafter KDHE STAFF RESPONSIVENESS SUMMARY].
} 
Bremby, the Secretary of KDHE, announced that the agency was denying Sunflower's application for a construction permit for the two plants. ${ }^{4}$

Sunflower's plans to construct and operate two new coal-fired power plants in Holcomb fueled a divisive debate in Kansas. That debate mirrors in some respects the divergence of views reflected in the quotations by former Vice President Al Gore and Kansas Senator Sam Brownback reproduced at the beginning of this Article. The Sunflower application drew significant support in the western part of the state and strong opposition in portions of eastern Kansas, conforming to one of the traditional fault lines on many politically charged issues within the state. ${ }^{5}$ The fate of the Sunflower units split the state's labor unions; the regional United Steelworkers opposed them, while the state AFL-CIO supported them. ${ }^{6}$ A majority of the Republican members of the state House of Representatives had sent a letter urging Kansas Governor Kathleen Sebelius, a Democrat, to approve the plants, arguing that without it, "our state and its citizens will lose access to the low-cost energy source and millions in economic development." " As a result of these opposing forces, KDHE's decision on the fate of the Sunflower plants was bound to generate controversy, no matter which way it went. ${ }^{8}$

While the denial of the Sunflower application might have stoked the fury of the project's supporters no matter what its basis, Secretary Bremby's justification for refusing to license the two new units was the real headline grabber." Bremby based his denial on the "substantial endangerment" to health and the environment in Kansas that would result

4. Letter from Roderick L. Bremby to Sunflower Electric Power Corporation, Mr. Wayne Penrod (Oct. 18, 2007) [hereinafter Bremby Letter]. A videotaped version of Bremby's decision, recorded on October 18, 2007, is available at http://www.kdheks.gov/press_room.htm (click on Video).

5. Opposition was especially strong in the region between Topeka and Kansas City. Steven Mufson, Power Plant Rejected over Carbon Dioxide for First Time, WAsH. Post, Oct. 19, 2007, at A1. Holcomb is in the southwestern part of Kansas, west of Dodge City and Garden City, north of Liberal, and relatively close to the Colorado border.

6. Id.

7. Id.

8. The results of one opinion poll released at the beginning of 2008 indicated that $62 \%$ of Kansans supported KDHE's decision to deny Sunflower's air permit application and 31\% opposed it. Scott Rothschild, Kansans Support Decision to Nix Power Plants, Want to Focus on Wind Energy, LAWRENCE J.-WORLD, Jan. 4, 2008, at A3, available at http://www2.ljworld. com/news/2008/jan/04/kansans_support_decision_nix_coal_plants_want_focu/. Lobbyists spent almost $\$ 800,000$, mostly on advertising, in an effort to turn public opinion against KDHE's decision. The Holcomb plants' supporters spent six times as much on lobbying as the plants' opponents. Kan. Lobbyists Spend Big to Defend Coal Plants, ClimateWire, Apr. 17, 2008.

9. See, e.g., Mufson, supra note 5. 
from carbon dioxide emissions generated by the plants' operation. ${ }^{10}$ According to some characterizations of the decision, the denial represented the first time that any state denied a permit for a large coalfired power plant solely because of its potential impact on climate change. ${ }^{11}$ The Holcomb plants' proponents not only attacked the denial on policy grounds, but also charged that the Secretary lacks the statutory or regulatory authority to deny an air pollution permit on the basis of its potential to contribute to climate change. Accordingly, they challenged the denial in both administrative and judicial forums. ${ }^{12}$ In addition, the 2008 session of the Kansas legislature was dominated by a furious effort by supporters of the proposed Holcomb plants to overturn the denial. That fight culminated in a close vote upholding Governor Sebelius' decision to veto three bills that would have reversed Secretary Bremby's decision and stripped KDHE of most of its authority to regulate emissions of carbon dioxide and other pollutants that contribute to climate change. ${ }^{13}$

This Article is not intended to dwell primarily on the policy debate surrounding Sunflower's proposal to build two new coal-fired units, although it addresses the policy implications of using coal or other resources to generate electricity. Instead, this Article focuses on the legality of KDHE's decision to refuse to issue a permit for the Holcomb units. The analysis of the legality of that decision is most immediately relevant to the outcome of litigation brought in the Kansas courts by Sunflower and other plant supporters to invalidate Secretary Bremby's decision. ${ }^{14}$ In addition, the contention in this Article that KDHE acted within the scope of its statutory authority in denying air quality permits for the Holcomb plants may be relevant to efforts by environmental agencies in other states to limit the contribution to climate change of coal-fired power plants or other industrial facilities that generate greenhouse gas emissions. In particular, the analysis may be relevant to decisions by those agencies to block the construction and operation of coal-fired power plants or other facilities based on legislation similar to

10. See infra notes $257-70$ and accompanying text.

11. See Matthew L. Wald, Citing Global Warming, Kansas Denies Plant Permit, N.Y. TIMES, Oct. 20, 2007, at C4.

12. See infra notes $287-295$ and accompanying text.

13. See infra notes $301-05$ and accompanying text.

14. At the time this Article was written, the Kansas legislature's efforts during the 2008 session to reverse Secretary Bremby's decision had reached an unsuccessful conclusion. If legislative efforts to reverse that decision are revived in future legislative sessions, or if an agreement is reached pursuant to which the agency voluntarily reverses its position, the Kansas courts might not reach the merits of the challenges to the denial that were filed after Secretary Bremby's decision. 
the endangerment provision cited by Secretary Bremby in denying operating permits for the proposed Holcomb units.

Part II of the Article serves two purposes. First, it provides background information on the degree to which coal-fired electric generating facilities in the United States contribute to climate change. Second, it provides regulatory context for KDHE's decision denying a permit for the Sunflower project. It summarizes the status of federal regulation of greenhouse gas ("GHG") emissions. It also describes state efforts to fill the void created by the virtual absence of a meaningful federal climate change program to date, especially in connection with stationary sources of GHGs. In particular, it provides examples of actions in several other states that reflect a broader nationwide (albeit not always coordinated) effort by state legislators and regulatory agencies to minimize the contribution of electric power generation to climate change.

Parts III and IV focus on the fate of the Holcomb units. Part III describes Sunflower's application, the Attorney General's opinion sought by KDHE on the disposition of that application, KDHE's decision to deny an air quality permit for the Holcomb units, and the aftermath of that decision. Part IV analyzes the legality of KDHE's denial of the Sunflower application. It addresses not only the relevant Kansas statutes, but also the case law construing the federal environmental statutes that mirror the Kansas statute primarily relied upon by KDHE. I conclude that the denial of air quality permits for the Sunflower units is within KDHE's authority to take actions to prevent the substantial endangerment to public health and the environment arising from GHG emissions. I reach this conclusion even though the denial was based on projected as opposed to ongoing emissions and even though, at the time of the decision, neither Kansas nor the federal government had designated GHGs as air pollutants for air quality regulatory purposes. Part V briefly assesses the implications of KDHE's decision for the future of coal-fired electricity generation and the development of an energy policy for Kansas in the climate change era.

\section{COAL, Electric Power, AND Global Climate Change}

Global climate change resonated as an environmental threat to a greater extent in 2007 than it ever has before. ${ }^{15}$ Throughout the year, the

15. See The Challenge that Will Define Our Age, 25 EnVTL. F. No. 1, Jan./Feb. 2008, at 20, 20 (predicting that "a quarter century from now, 2007 will stand out as a watershed" that "saw a complete makeover in humanity's views on global warming - even in the United States, large majorities now want immediate action"). 
Intergovernmental Panel on Climate Change ("IPCC") 16 issued a series of reports that surveyed the latest scientific developments in climate change, culminating in a Synthesis Report issued in November 2007. ${ }^{17}$ Climate change also generated international headlines in October 2007 when the Norwegian Nobel Committee selected former Vice President $\mathrm{Al}$ Gore and the IPCC as joint recipients of the Nobel Peace Prize. ${ }^{18}$ The year ended with a meeting in Bali, Indonesia of the United Nations Climate Change Conference pursuant to the United Nations Framework Convention on Climate Change. ${ }^{19}$ At that meeting, representatives of more than 180 nations adopted "the Bali roadmap, which charts the course for a new negotiating process to be concluded by 2009 that will ultimately lead to a post-2012 international agreement on climate change." 20

In addition to these events of international scope, climate change garnered headlines as a result of legal developments of national significance within the United States. In April 2007, the U.S. Supreme Court decided in Massachusetts v. EPA $A^{21}$ that the federal Clean Air Act

16. The IPCC describes itself as "a scientific intergovernmental body set up by the World Meteorological Organization (WMO) and by the United Nations Environment Programme (UNEP)" to

provide the decision-makers and others interested in climate change with an objective source of information about climate change. The IPCC does not conduct any research nor does it monitor climate related data or parameters. Its role is to assess on a comprehensive, objective, open and transparent basis the latest scientific, technical and socio-economic literature produced worldwide relevant to the understanding of the risk of human-induced climate change, its observed and projected impacts and options for adaptation and mitigation.

InTERgovernmental PANEL ON Climate CHANGE, ABOUT IPCC, http://www.ipcc.ch/ about/index.htm (last visited Mar. 1, 2008). "[T] he IPCC is open to all member countries of WMO and UNEP" and "hundreds of scientists all over the world contribute to the work of the IPCC as authors, contributors and reviewers." Id.

17. Intergovernmental Panel on Climate Change, Fourth Assessment Report, Climate CHANGe 2007: SyNTHEsis REPORT, SUMMARY FOR POLICYMAKERS (2007), available at http://www.ipcc.ch/pdf/assessment_report/ar4/syr/ar4_syr_spm.pdf [hereinafter IPCC SYNTHESIS REPORT]. The Synthesis Report summarizes reports of the IPCC's three Working Groups issued earlier in 2007. The first Working Group report dealt with "The Physical Science Basis" for climate change; the second Working Group report covered "Impacts, Adaptation, and Vulnerability;" and the report of Working Group III analyzed "Mitigation of Climate Change." All three reports are available in full at http://www.ipcc.ch/ipccreports/assessments-reports.htm.

18. See The Norwegian Nobel Committee, The Nobel Peace Prize for 2007 (Oct. 12, 2007), http://nobelpeaceprize.org/eng_lau_announce2007.html.

19. United Nations Conference on Environment and Development: Framework Convention on Climate Change, U.N. Doc. A/CONF.151/26, reprinted in 31 I.L.M. 849 (1992)

20. United Nations Framework Convention on Climate Change, The United Nations Climate Change Conference in Bali, http://unfccc.int/meetings/cop 13/items/4049.php (last visited Mar. 2, 2008). This website links to all of the official documents approved at the Bali conference.

21. 127 S. Ct. 1438 (2007). 
("CAA") 22 vests authority in the Environmental Protection Agency ("EPA") to regulate GHG emissions from mobile sources ${ }^{23}$ and that EPA failed to provide a "reasoned explanation" for denying a petition by states and environmental groups to exercise that authority by regulating GHG emissions from motor vehicles. ${ }^{24}$ Later in the year, two federal district courts rejected claims that federal law preempts state restrictions on GHG emissions from cars and trucks. ${ }^{25}$ As the year drew to a close, Congress passed the Energy Independence and Security Act of 2007, which requires the Secretary of Transportation to phase in corporate average fuel economy standards between model years 2011 and 2020 of at least thirty-five miles per gallon for the total fleet of passenger and non-passenger automobiles manufactured in a model year. ${ }^{26}$ According to the White House, this increase in the fuel economy standards first developed under the Energy Policy and Conservation Act of 1975 $\left(\right.$ "EPCA") ${ }^{27}$ "represents a major step forward in expanding the production of renewable fuels, reducing our dependence on oil, and confronting global climate change." 28 Finally, on the same day that President Bush signed the 2007 energy legislation, EPA denied California's request that EPA waive the CAA's prohibition on state mobile source emission standards so that California could implement legislation restricting GHG emissions from motor vehicles. ${ }^{29}$

22. 42 U.S.C. $\S \S 7401-7671 \mathrm{q}(2000)$.

23. Section 202(a) of the CAA provides that EPA's Administrator "shall by regulation prescribe ... standards applicable to the emission of any air pollutant from any class or classes of new motor vehicles... which, in his judgment cause, or contribute to, air pollution which may reasonably be anticipated to endanger public health or welfare." 42 U.S.C. § 7521(a). The Court held that because GHGs "fit well within the [CAA's] capacious definition of 'air pollutant,' ... EPA has the statutory authority to regulate [GHGs]." Massachusetts v. EPA,127 S. Ct. at 1462.

24. Massachusetts v. EPA, $127 \mathrm{~S}$. Ct. at 1463.

25. Cent. Valley Chrysler-Jeep, Inc. v. Goldstene, 529 F. Supp. 2d 1151 (E.D. Cal. 2007); Green Mountain Chrysler Plymouth Dodge Jeep v. Crombie, 508 F. Supp. 2d 295 (D. Vt. 2007). Neither decision addressed whether the CAA preempts state regulation of GHG emissions from mobile sources. Instead, they decided that neither the Energy Policy Conservation Act of 1975 nor the federal government's power to conduct foreign policy preempted the California or Vermont regulations challenged in those cases.

26. Pub. L. No. 110-140, § 102(a), 121 Stat. 1492 (2007) (to be codified at 49 U.S.C. § 32902(a)(1)).

27. Pub. L. No. $94-163, \S 301,89$ Stat. 871 (1975) (codified as amended at 49 U.S.C. $\S \S$ 32906-32919 (2000)).

28. The White House, Fact Sheet: Energy Independence and Security Act of 2007 (Dec. 19, 2007), http://www.whitehouse.gov/news/releases/2007/12/20071219-1.html. Because the combustion of motor gasoline by motor vehicles is a major source of carbon dioxide emissions, increasing the corporate average fuel economy standards can reduce $\mathrm{CO}_{2}$ emissions by requiring auto manufacturers to produce vehicles that use less fuel for each mile traveled.

29. See Press Release, U.S. Environmental Protection Agency, America Receives a National Solution for Vehicle Greenhouse Gas Emissions (Dec. 19, 2007), available at http://yosemite.epa. gov/opa/admpress.nsf/d0cf6618525a9efb85257359003fb69d/41b4663d8d3807c5852573b6008141e 
Amidst all of this internationally and nationally important activity, it would be easy to overlook the denial by KDHE of an application to construct two new coal-fired electricity generating units. The decision merits attention, however, for several reasons. First, coal-fired power plants comprise a significant portion of the GHGs emitted in the United States. Second, KDHE's denial of Sunflower's permit application was not the only state action in 2007 that suspended or stopped plans to build coal-fired power plants based on the impact the plants might have on climate change. Washington, Florida, North Carolina, and other states reached similar decisions, indicating that KDHE's decision is not an aberration. Instead, its decision is consistent with a trend toward a reduced role across the country for coal-fired power in the generation of electricity. ${ }^{30}$ Between 2000 and 2006, utilities announced plans to build more than 150 coal plants. ${ }^{31}$ By the end of 2007, ten of those had been constructed and another twenty-five were in the process of being constructed. $^{32}$ Plans for at least fifty-nine of the proposed coal plants were halted or suspended in 2007 alone, however. ${ }^{33}$ Of those, fifteen were rejected by state or local regulators or courts. ${ }^{34}$ Third, Kansas is not

5!OpenDocument. According to EPA Administrator Stephen L. Johnson, the denial allowed the Bush Administration to " $\operatorname{mov}[\mathrm{e}]$ forward with a clear national solution - not a confusing patchwork of state rules." Id. Within two weeks of the denial, California sued EPA in the Court of Appeals for the Ninth Circuit, claiming that the denial was erroneous. Bob Egelko, State Fights Back-Sues EPA on Greenhouse Gas Emissions, S.F. CHRON., Jan. 3, 2008, at 1. EPA issued its formal notice denying California's waiver application in March 2008. California State Motor Vehicle Pollution Control Standards; Notice of Decision Denying a Waiver of Clean Air Act Preemption for California's 2009 and Subsequent Model Year Greenhouse Gas Emission Standards for New Motor Vehicles, 73 Fed. Reg. 12,156 (Mar. 6, 2008). The provisions of the CAA relevant to the denial of California's waiver application are section 209(a), 42 U.S.C. § 7543(a) (2000) (prohibiting the adoption or enforcement of state standards controlling emissions from new motor vehicles subject to the CAA); section 209(b), 42 U.S.C. $\$ 7543$ (b) (authorizing EPA to waive the prohibition for California, the only state that adopted emission standards before March 30, 1966); and section 177, 42 U.S.C. $\S 7507$ (allowing other states to adopt standards identical to any California standard for which EPA has issued a preemption waiver).

30. See Marc Gunther, Coal Plants Get Burned, Fortune MAg., Mar. 2, 2007 ("These are troubled times for any company trying to build a coal-fired power plants [sic] . . . Opposition is mounting to coal plants because they contribute to global warming.").

31. SourceWatch, Coal Plants Cancelled in 2007, http://www.sourcewatch.org/index.php? title $=$ Coal plants cancelled in 2007 (last visited Apr. 4, 2008).

32. Id.

33. Id.

34. See id. (finding that concerns about climate change played a major role in cancellation or abandonment of coal plant proposals in fifteen states); see also Rebecca Smith, Coal's Doubters Block New Wave of Power Plants, WaLl ST. J., July 25, 2007, at A1 (stating that U.S. power companies had announced plans to build up to 150 new coal-fired plants, but that "as plans for this fleet of new coal-powered plants move forward, an increasing number are being canceled or development slowed," in large part due to concern over the impacts of $\mathrm{CO}_{2}$ emissions on climate change). According to that article, written before KDHE's denial of the Sunflower permit application, decisions in several states blocking coal-fired plants "have shown that coal's future 
normally one of the states that quickly come to mind when listing the states that have taken leadership roles in the past in developing innovative environmental policies. KDHE's denial (whether or not it is ultimately upheld in court or withstands legislative challenge) may be a sign, therefore, that the momentum in favor of government action to address climate change has reached deep into the nation's heartland, even if it has not yet made much of an impact on Pennsylvania Avenue. ${ }^{35}$

\section{A. What's Coal Got to Do with It?}

The denial of Sunflower's application to construct two coal-fired generating units and similar actions in other states that restrict the construction or operation of coal-fired electric generating facilities are premised on a link between the GHGs that coal-fired power plants emit and exacerbation of the adverse effects of climate change. The following two subsections briefly describe the current scientific understanding of the causes of climate change and the role of coal-fired power production in the United States in contributing to it.

\section{Anthropogenic Activity, Greenhouse Gases, and Climate Change}

The consensus of most mainstream scientists around the world who are interested in climate change is that climate change is occurring, that human activity is at least a significantly contributing factor, and that the generation of GHGs through the combustion of fossil fuels is one of the primary culprits. ${ }^{36}$ The IPCC's Fourth Assessment Report, for example, endorses all of these postulates. The IPCC concluded that "[w]arming of the climate system is unequivocal," as reflected in increases in global air and ocean temperatures, widespread melting of snow and ice, and rising

prospects are dimming." Id. The factors that have induced utilities to cancel coal-fired projects have included rising construction costs, inadequate financing, reduced demand, and concerns about future regulation of GHGs. See SourceWatch, supra note 31. Cf. John G. Edwards, Coal Plant Plans Fade Across U.S., LAS VEGAS REV.-J., Jan. 4, 2008, at D1 (citing environmental group's claim that twenty-six coal-fired power plants were scrapped between March 2006 and the end of 2007).

35. See Editorial, The One Environmental Issue, N.Y. TIMES, Jan. 1, 2008, at A16 ("The overriding environmental issue of these times is the warming of the planet.... There is also a growing appetite for decisive action - everywhere, it seems, except the White House.").

36. Climate change skeptics remain, both inside and outside the scientific community. The non-scientists sometimes couch their doubts sarcastically. See, e.g., John Tierney, Editorial, In 2008, a 100 Percent Chance of Alarm, N.Y. TIMES, Jan. 1, 2008, at D1 (describing how journalists and scientists use "hurricanes, wild fires and starving polar bears" to make global warming seem real to the public at large); George F. Will, Editorial, Fuzzy Climate Math, WASH. Post, Apr. 27, 2007, at A27 (describing the "indoctrination" of Americans on climate change and the production of Ben \& Jerry's ice cream as a "sinister" contributor to climate change). 
sea levels. ${ }^{37}$ The IPCC attributed various additional changes (such as changes in both hydrological and terrestrial systems) to rising temperatures with either a high or very high degree of confidence. ${ }^{38}$

Global GHG emissions due to human activities have increased since pre-industrial times, and have increased by $70 \%$ between 1970 and 2004 . According to the IPCC, carbon dioxide (" $\mathrm{CO}_{2}$ ") "is the most important anthropogenic GHG," with increased annual emissions of about $80 \%$ from 1970 to $2004 .^{39}$ As a result, global atmospheric concentrations of $\mathrm{CO}_{2}$ and other GHGs (including methane and nitrous oxide) have increased dramatically and now "exceed by far the natural range over the last 650,000 years." "40 The increased concentrations of GHGs "are due primarily to fossil fuel use, with land-use change providing another significant but smaller contribution." 41 The IPCC's Fourth Assessment Report also concluded that " $[\mathrm{m}]$ ost of the observed increase in globallyaveraged temperatures since the mid-20th century is very likely due to the observed increase in anthropogenic GHG concentrations." ${ }^{42}$ Human

37. IPCC SYNTHESIS REPORT, supra note 17, at 1. The IPCC reported that eleven of the years between 1995 and 2006 rank among the twelve warmest years since 1850, when instrumental recording of global surface temperatures began. Further, the increases have been widespread, although they have generally been greater at higher northern latitudes. $I d$.

38. Id. at $2-3$.

39. Id. at 4. The National Research Council has referred to $\mathrm{CO}_{2}$ as "the chief GHG." Massachusetts v. EPA, 415 F.3d 50, 62 (D.C. Cir. 2005) (Tatel, J., dissenting) (quoting COMMITTEE on the Science of Climate Change, Division on Earth and Life Studies, National Research Council, Climate Change Science: An Analysis of Some Key Questions (2001), available at $\mathrm{http}: / / \mathrm{www} . n a p . e d u / c a t a l o g . p h p ? \mathrm{record} \mathrm{id}=10139)$, reh'g en banc denied, $433 \mathrm{~F} .3 \mathrm{~d} 66$ (D.C. Cir. 2005), rev'd, 127 S. Ct. 1438 (2007). $\mathrm{CO}_{2}$ is "[t]he most important greenhouse gas" because "[i]t is emitted in by far the greatest quantities," even though other GHGs are more potent than $\mathrm{CO}_{2}$. Michael B. Gerrard, Introduction and Overview, in Global Climate ChANGE AND U.S. LAW 5 (Michael B. Gerrard ed., 2007). Methane, another GHG, has a global warming potential ("GWP") of twenty-three; "it is 23 times more potent than carbon dioxide on a ton-by-ton basis." Id. The GWP of nitrous oxide is 296 , while the GWP of sulfur hexafluoride is 22,200. Id.

40. IPCC SYNTHESIS REPORT, supra note 17, at 4.

41. Id.

42. Id. at 5. The majority opinion in Massachusetts v. EPA began with the following description of this causal link:

A well-documented rise in global temperatures has coincided with a significant increase in the concentration of carbon dioxide in the atmosphere. Respected scientists believe the two trends are related. For when carbon dioxide is released into the atmosphere, it acts like the ceiling of a greenhouse, trapping solar energy and retarding the escape of reflected heat. It is therefore a species - the most important species - of a "greenhouse gas."

127 S. Ct. 1438, 1446 (2007). Chief Justice Roberts, who concluded that the plaintiffs lacked standing to sue, was not willing to concede the existence of a problem, much less a causal link between human activity and that problem. See id. at 1463 (Roberts, C.J., dissenting) ("Global warming may be a 'crisis'.... Indeed, it may ultimately affect nearly everyone on the planet in some potentially adverse way ....”). Cf. id. at 1477-78 (Scalia, J., dissenting) (“The Court's alarm over global warming may or may not be justified ...."). 
activities extend to other aspects of climate change. They are very likely, for example, to have contributed to sea level rise over the second half of the 20th century and likely to have contributed to wind pattern changes that affect extra-tropical storm track and temperature patterns. ${ }^{43}$

According to the IPCC's Fourth Assessment Report, "[t]here is high agreement and much evidence" that if current environmental policies are not changed, global GHG emissions will continue to increase, causing further warming and other climate changes during this century "that would very likely be larger than those observed during the 20th century." 44 Although the changes would differ across the globe, they are very likely or likely to include reduction or disappearance of late summer sea ice in the Arctic (with resulting increases in sea levels), increased frequency of hot extremes and heavy precipitation, increased tropical cyclone intensity, ${ }^{45}$ changes in annual river runoff patterns, and decreased water resources in semi-arid areas such as the western United States. ${ }^{46}$ Additional projected changes that will affect the United States include warming in the western mountains, causing reduced snowpack, increased winter flooding, and decreased summer flows that result in fiercer competition for scarce water resources; slight increased aggregate yields of rain-fed agriculture during the early years of the 21 st century, but " $[\mathrm{m}]$ ajor challenges are projected for crops that are near the warm end of their suitable range or which depend on highly utilized water resources[;] increased number, intensity and duration of heatwaves," which may cause adverse health impacts; and increased stresses on coastal communities. ${ }^{47}$ The IPCC Report warned that anthropogenic warming could lead to abrupt or irreversible changes, including sea level rises measured in meters, major changes in coastlines and flooding of low-lying areas, and species extinctions. ${ }^{48}$

\footnotetext{
43. IPCC SYNTHESIS REPORT, supra note 17, at 6.

44. $I d$.

45. For discussion of the debate over whether there is a link between human-induced climate change and tropical storms such as hurricanes in the Atlantic Ocean, see Robert L. Glicksman, Global Climate Change and the Risks to Coastal Areas from Hurricanes and Rising Sea Levels: The Costs of Doing Nothing, 52 LOY. L. REV. 1127, 1184-97 (2006).

46. IPCC SYNTHESIS REPORT, supra note 17 , at 8.

47. Id. at 10 .

48. Id. at 13
} 
2. Coal, Electricity, and GHG Emissions in the United States

The United States is responsible for between 20 and 25\% of global $\mathrm{CO}_{2}$ emissions. $^{49}$ Nearly $85 \%$ of total U.S. GHG emissions (measured by global warming potential) are from $\mathrm{CO}_{2} .{ }^{50}$ Based on data from 2004, the United States emits on a per capita basis two times the $\mathrm{CO}_{2}$ that Great Britain and Japan do, more than five times the amount China emits, and nineteen times more than India. ${ }^{51}$ Between 1990 and 2004, U.S. emissions of all GHGs increased by $15.8 \%$ and emissions of $\mathrm{CO}_{2}$ increased by $19.6 \% .^{52}$ The largest sources of $\mathrm{CO}_{2}$ emissions in the United States are power plants and transportation sources. ${ }^{53}$ In 2005, about $40 \%$ of $\mathrm{CO}_{2}$ emissions and $84 \%$ of all GHG emissions from U.S. energy sources came from power plants. ${ }^{54}$ The electric power sector was primarily responsible for the increase in U.S. emissions of $\mathrm{CO}_{2}$ between 1990 and 2004; $55 \%$ of the emissions increase came from that sector. ${ }^{55}$ Because coal has the highest carbon content of any fossil fuel, burning coal to produce electricity generates more carbon emissions per unit of energy than burning oil or natural gas does. ${ }^{56}$ Between 1990 and 2004, $\mathrm{CO}_{2}$ emissions in the United States from coal-fired power plants

49. See, e.g., EDITH BROWN WEISS ET AL., INTERNATIONAL ENVIRONMENTAL LAW AND POLICY 649 (2007) (explaining the U.S.'s responsibility for $25 \%$ of global $\mathrm{CO}_{2}$ emissions). Cf. Gerrard, supra note 39, at 6 (asserting the U.S. was responsible for $20.6 \%$ of worldwide GHG emissions in 2000). By some accounts, China has overtaken the United States as the world's biggest emitter of $\mathrm{CO}_{2}$. See, e.g., John Vidal \& David Adam, China Overtakes US as World's Biggest CO Emitter, GUARDIAN UNLIMITED (U.K.), June 19, 2007, http://www.guardian.co.uk/ environment/2007/jun/19/china.usnews.

50. Gerrard, supra note 39 , at 8 .

51. U.S. PIRG Educ. Fund, The CARbon Boom: State and National Trends in Carbon DIOXIDE EMISSIONS SINCE 19909 (2007), available at http://www.uspirg.org/uploads/ up/WJ/upWJ1agKj7szeI-OUSnI1A/carbonboom07.pdf [hereinafter CARBON BOOM].

52. U.S. EnVtl. Prot. Agency, U.S. EMissions InVENTORY 2006, InVENTORY OF U.S. GREENHOUSE GAS EMISSIONS AND SINKS: 1990-2004 2-1 (2006), available at http://yosemite. epa.gov/OAR/globalwarming.nsf/UniqueKeyLookup/RAMR6MBSC3/\$File/06 Complete Report.p df [hereinafter EMISSIONS INVENTORY 2006]. During the same period, U.S. emissions of some other GHGs, such as methane and nitrous oxide, fell (by $10 \%$ and $2 \%$, respectively). Id. at 2-5.

53. CARBON BOOM, supra note 51 , at 4.

54. Id. at 9; ANDREW G. KeEler, NAT'L REgUlatory RESEARCH InST., STATE COMMisSiON Electricity Regulation Under a Federal GreEnhouse Gas CAP-AND-Trade Policy 2-3 (2008), available at http://nrri.org/pubs/electricity/08-01.pdf. See also Gerrard, supra note 39, at 9 (providing a 39\% figure for 2004).

55. CARBON BOOM, supra note 51, at 5; see also EMISSIONS INVENTORY 2006, supra note 52, at 2-22 ("[E]missions from electricity generation accounted for the largest portion (33\%) of U.S. greenhouse gashouse emissions in 2004.”).

56. Those two fossil fuels contain about $25 \%$ and $45 \%$ less carbon than coal, respectively. CARBON BOOM, supra note 51, at 19. 
increased by about a quarter, representing about $75 \%$ of the emissions increase in the electric power sector and $42 \%$ of all $\mathrm{CO}_{2}$ emissions increases. ${ }^{57}$ During the same period, $\mathrm{CO}_{2}$ emissions from the industrial sector fell slightly and increases from the commercial and residential sectors amounted to only $4 \%$ and $9 \%$, respectively. ${ }^{58}$ Increases in $\mathrm{CO}_{2}$ emissions have continued since then: During the first forty-nine weeks of 2007, they rose $3.3 \%$ compared to the same period during the previous year. $^{59}$

Different regions of the United States rely to a different extent on coal-fired power plants to generate electricity. The ten states that emitted the highest amounts of $\mathrm{CO}_{2}$ in 2004 were (in descending order): Texas, California, Pennsylvania, Ohio, Florida, Indiana, Illinois, New York, Louisiana, and Mississippi. ${ }^{60}$ The ten states whose $\mathrm{CO}_{2}$ emissions increased the most between 1990 and 2004 were: Texas, Florida, Illinois, North Carolina, Georgia, Missouri, Arizona, Indiana, Virginia, and Alabama. ${ }^{61} \mathrm{CO}_{2}$ emissions from the plains states (Iowa, Kansas, Missouri, Nebraska, and the Dakotas) rose by $24 \%$ between 1990 and 2004, behind only the Southeast and the Mountain West (where emissions increased by $31 \%$ in each region). ${ }^{62}$ The top ten states for $\mathrm{CO}_{2}$ emissions from coal-fired power plants in 2004 were: Texas, Ohio, Indiana, Pennsylvania, Illinois, Kentucky, West Virginia, Georgia, Missouri, and Alabama. ${ }^{63}$ Between 1990 and 2004, the plains states experienced a $40 \%$ increase in $\mathrm{CO}_{2}$ emissions from coal-fired power plants, second only to the Pacific West (where emissions increased by $65 \%) .{ }^{64}$

About half of the nation's electric power is provided by coal combustion, but about three-quarters of power in Kansas comes from coal. ${ }^{65}$ Energy-related $\mathrm{CO}_{2}$ emissions from all sources in Kansas totaled

57. Id.

58. Id. at 16 tbl. 1.

59. U.S. Coal Use Rises, Boosting $\mathrm{CO}_{2}$ Emissions in 2007, GREENWIRE (Dec. 14, 2007), http://www.eenews.net/Greenwire/print/2007/12/14/13.

60. CARBON BOOM, supra note 51 , at 17 tbl. 3 .

61. Id. at 18 tbl. 4 .

62. Id. at $17 \mathrm{tbl} .2$.

63. Id. at 20 tbl. 6. But $c f$. CleAn Air WATCH, FloridA's DiRTy Dozen: MeEting THE Sunshine State's Greenhouse Gas Reduction GoAls 3 (2008) (listing Florida as the third largest emitter of $\mathrm{CO}_{2}$ from power plants) (citing U.S. EIA, Florida Electricity Profile, 2006 Edition, available at http://www.eia.doe.gov/cneaf/electricity/st_profiles/florida.html)), available at http:// www.cleanairwatch.org/Documents\%20\&\%20Reports/Florida\%20Dirty\%20Dozen.pdf [hereinafter DIRTY DOZEN].

64. CARBON BOOM, supra note 51, at 19-20.

65. Governor Says Rejection of Air Permit for Power Plant Will Improve Public Health, 38 ENV'T REP. (BNA) 2363, 2364 (Nov. 2, 2007) [hereinafter Rejection]. According to Kansas 
67.7 million metric tons in 1990 and 76.1 million metric tons in 2004, an increase of $12 \%{ }^{66}$ Emissions of $\mathrm{CO}_{2}$ from coal-fired power plants in Kansas rose from 25.2 million metric tons in 1990 to 35.9 million metric tons in 2004, a $42 \%$ increase. ${ }^{67}$ Kansas generated 23.7 million megawatt hours of electricity from coal in 1990 and 34.6 million in 2004, a 46\% increase. $^{68}$ Clearly, then, coal-fired power production is a significant component of the energy mix in Kansas, and increasingly so in recent years.

\section{B. Regulatory Restrictions on Coal-Fired Power Generation}

Because electricity production, and coal-fired power plants in particular, contribute significantly to $\mathrm{CO}_{2}$ emissions in the United States, coal-fired power generation is a logical candidate for emission controls or other regulatory restrictions designed to mitigate climate change. This section summarizes the regulatory status of electric generating facilities under both federal and state air pollution and related laws. As the discussion below indicates, state governments have played the primary role to date in restricting $\mathrm{CO}_{2}$ and other GHG emissions from electric generating facilities.

\section{Federal Regulation}

For years, EPA denied that it had the authority to regulate emissions of $\mathrm{CO}_{2}$ and most other GHGs under the CAA. In 2007, the Supreme Court decisively rejected EPA's claim that it lacks the authority to regulate GHG emissions from mobile sources under section 202 of the CAA. ${ }^{69}$ The Court held in Massachusetts v. EPA that GHGs "fit well within the [CAA's] capacious definition of 'air pollutant.",70 The Court found that section 202 conditions the exercise of that authority on the exercise of EPA's judgment, but that such judgment "must relate to whether an air pollutant 'cause[s] or contribute[s] to air pollution which

Governor Kathleen Sebelius, Kansas ranks tenth in the nation in per capita production of GHGs. Id.

66. CARBON BoOM, supra note 51, at 35 app. A.

67. Id. at 37 app. B.

68. Id.

69. 42 U.S.C. § 7521(a) (2000) (mandating that EPA issue "standards applicable to the emission of any air pollutant" from motor vehicles which, in the Administrator's judgment, "may reasonably be anticipated to endanger public health or welfare").

70. 127 S. Ct. 1438, 1462 (2007). The Act defines "air pollutant" as "any air pollution agent or combination of such agents, including any physical, chemical, biological, radioactive (including source material, special nuclear material, and byproduct material) substance or matter which is emitted into or otherwise enters the ambient air." 42 U.S.C. $\$ 7602(\mathrm{~g})$. 
may reasonably be anticipated to endanger public health or welfare.",71 Thus, if EPA makes a finding of endangerment, it must regulate emissions of the relevant pollutant from motor vehicles. ${ }^{72}$ The issue in Massachusetts v. EPA, therefore, was whether EPA had offered a reasoned explanation for refusing to decide whether the effects of GHG emissions pose an endangerment. The Court held that it had not done so. ${ }^{73}$ EPA has not yet responded to the Court's decision, but the agency would seem to have an uphill battle defending a finding that GHGs do not cause or contribute to an endangerment. ${ }^{74}$

Massachusetts v. EPA did not involve EPA's authority to regulate GHGs from stationary sources such as electric generating facilities. The Court's holding nevertheless almost assuredly supports the conclusion that the CAA authorizes EPA to regulate GHG emissions from stationary sources as well as mobile sources. The CAA creates several different regulatory programs that apply to stationary sources, most of which also apply to "air pollutants" for which the agency makes certain findings. Because the definition of an "air pollutant" is the same in each of those contexts, GHG emissions from stationary sources as well as motor vehicles qualify as air pollutants. The CAA authorizes EPA to issue national ambient air quality standards to protect the public health and welfare. $^{75}$ It requires that EPA list as a so-called "criteria pollutant"

71. Massachusetts v. EPA, 127 S. Ct. at 1462 (quoting 42 U.S.C. $\S 7521(\mathrm{a})(1)$ ).

72. Id.

73. Id. at $1462-63$.

74. See, e.g., Jonathan H. Adler, Massachusetts v. EPA Heats Up Climate Policy No Less than Administrative Law: A Comment on Professors Watts and Wildermuth, 102 NW. U. L. REV. COLlOQuY 32, 37 (2007) ("Barring congressional intervention, this decision will cause the EPA to regulate the emission of greenhouse gases."); Robert L. Glicksman \& Richard E. Levy, A Collective Action Perspective on Ceiling Preemption by Federal Environmental Regulation: The Case of Global Climate Change, 102 Nw. U. L. REV. 579 (2008) (stating that the Court's decision "all but forc[es] the EPA to regulate GHG emissions"); Arnold W. Reitze, Jr., Controlling Greenhouse Gas Emissions from Mobile Sources-Massachusetts v. EPA, 37 ENVTL. L. REP. 10,535, 10,538 (2007) ("[T]he Court's opinion pushes EPA to find that GHGs need to be regulated."). Late in 2007, President Bush signed the Energy Independence and Security Act of 2007. Pub. L. No. 110-140, 121 Stat. 1492 (2007). That Act raised the corporate average fuel economy standards for passenger automobiles to 35 miles per gallon by 2020. Id. $\S 102(\mathrm{a})(2)$ (to be codified at 49 U.S.C. $\S$ 32902(b)(2)(A)). EPA Administrator Stephen Johnson hinted that the energy bill makes it unnecessary for EPA to adopt mandatory controls on GHG emissions from motor vehicles, despite Massachusetts v. EPA. See Dawn Reeves, Environmentalists Eye Suit to Force EPA GHG Endangerment Finding, INSIDE EPA WEEKLY, Jan. 4, 2008, at 1, 1 ("Johnson suggested that the fuel economy mandates may satisfy [Massachusetts v. EPA]."); Stephen D. Cook, Waxman Opens Investigation into Denial of California's Greenhouse Gas Limit Waiver, 39 ENV'T REP. (BNA) 12, 12-13 (Jan. 4, 2008) (quoting Johnson as stating that the energy bill amounts to a "comprehensive solution" for motor vehicles).

75. The CAA defines "welfare" broadly to include, but not be limited to, "effects on soils, water, crops, vegetation, manmade materials, animals, wildlife, weather, visibility, and climate, damage to and deterioration of property, and hazards to transportation, as well as effects on 
"each air pollutant" whose emissions, in the Administrator's judgment, "cause or contribute to air pollution which may reasonably be anticipated to endanger public health or welfare" and whose presence "in the ambient air results from numerous or diverse mobile or stationary sources." ${ }^{, 76}$ The similarity of the findings that trigger the obligation to list air pollutants as criteria pollutants and to regulate emissions from motor vehicles is obvious. Once EPA lists a pollutant as a criteria pollutant, it must establish national ambient air quality standards for the pollutant. ${ }^{77}$ The CAA then requires each state to develop an implementation plan that is designed to achieve the standards through techniques such as enforceable emission limitations. ${ }^{78}$ EPA and the states share the authority to enforce plan provisions. ${ }^{79}$

The suitability of the national ambient air quality standard provisions to restricting emissions of GHGs is not clear because those provisions make the states responsible for achieving or maintaining concentrations of the criteria pollutants involved that are measured locally. The effects of GHG emissions are not localized. ${ }^{80}$ The point is moot at the present time because EPA has given every indication that it has no intention to regulate GHGs from stationary sources, under the CAA's national ambient air quality standard provisions or otherwise, in order to combat climate change. $^{81}$

Another of the CAA's regulatory programs that could provide the basis for regulating GHG emissions from electric generating facilities addresses air pollution from new stationary sources. Section 111 of the statute requires that EPA compile a list of categories of stationary

economic values and on personal comfort and well-being, whether caused by transformation, conversion, or combination with other air pollutants." 42 U.S.C. $§ 7602(\mathrm{~h})$ (2000) (emphasis added).

76. $I d . \S 7408(\mathrm{a})(1)(\mathrm{A})-(\mathrm{B})$.

77. Id. $\S 7409(\mathrm{~b})$.

78. Id. $\S 7410(\mathrm{a})(1)-(2)$.

79. Id. $\S 7413$.

80. See Erwin Chemerinsky et al., California, Climate Change, and the Constitution, 37 ENVTL. L. REP. 10,653, 10,653 (2007) ("The threat of climate change does not hinge on where GHG emissions occur. On the contrary, because these gases quickly assimilate into the global atmosphere, emissions in Florence, Italy, have the same global impact as those released in Florence, California.")

81. The portion of EPA's Web site that describes EPA's plan for addressing climate change notably lacks any reference to mandatory federal controls on GHG emissions from stationary sources. See U.S. Envtl. Prot. Agency, Current and Near-Term Greenhouse Gas Reduction Initiatives, http://www.epa.gov/climatechange/policy/neartermghgreduction.html (last visited Mar. 2, 2008). Similarly, the George W. Bush Administration fought against the adoption of mandatory targets for reducing GHG emissions at the 2007 Bali Climate Change Conference. See Joshua Boak, U.S. Firms Urge Emissions Goal, CHI. TRIB., Dec. 15, 2007, at 1, available at http://www. chicagotribune.com/business/chi-sat_balibizdec15,1,7573594.story. 
sources $^{82}$ that, in the Administrator's judgment, "cause[], or contribute[] significantly to, air pollution which may reasonably be anticipated to endanger public health or welfare." ${ }^{\circ 3}$ EPA must establish nationally uniform, technology-based standards of performance for each listed source category. ${ }^{84}$ The Act makes it unlawful for any new source to operate in violation of an applicable standard of performance. ${ }^{85}$ Because the new source standards of performance determine the required degree of emission controls on the basis of what is technologically possible, rather than on the basis of the impact of different levels of emissions on ambient air quality, the non-localized nature of GHG emissions would not hinder efforts to address climate change through section 111 of the CAA. $^{86}$

82. Section 111 defines a "stationary source" as "any building, structure, facility, or installation which emits or may emit any air pollutant." 42 U.S.C. § 7411(a)(3); see also id. § 7602(z) ("The term 'stationary source' means generally any source of an air pollutant except those emissions resulting directly from an internal combustion engine for transportation purposes or from a nonroad engine or nonroad vehicle ....").

83. Id. $\S 7411(\mathrm{~b})(1)(\mathrm{A})$.

84. Id. $\S 7411(\mathrm{~b})(1)(\mathrm{B})$. A standard of performance

means a standard for emissions of air pollutants which reflects the degree of emission limitation achievable through the application of the best system of emission reduction which (taking into account the cost of achieving such reduction and any nonair quality health and environmental impact and energy requirements) the Administrator determines has been adequately demonstrated.

Id. $\S 7411(\mathrm{a})(1)$.

85. Id. $\S 7411(\mathrm{e})$.

86. Regulation under section 111 would be limited to sources that qualify as new sources, however. A new source "means any stationary source, the construction or modification of which is commenced after the publication of regulations (or, if earlier, proposed regulations) prescribing a standard of performance under this section which will be applicable to such source." Id. § 7411(a)(2). Coal-fired power plants that predate the adoption of section 111 standards for stationary source categories that emit GHGs would therefore not be covered by those standards, at least until they make physical changes that qualify as modifications. EPA refused in 2008 to regulate emissions of $\mathrm{CO}_{2}$ and other GHGs when it issued standards of performance for new stationary sources in the petroleum refining industry. U.S. Envtl. Prot. Agency, Standards of Performance for Petroleum Refineries, Final Rule, http://www.epa.gov/ttn/oarpg/t1_notices/nsps_043008.pdf. According to EPA, the CAA affords it "significant flexibility in determining which pollutants are appropriate for regulation under section 111(b)(1)(B)." Id. at 94. In addition, EPA asserted that nothing in the CAA "mandates that EPA include a new standard of performance for an air pollutant not already covered by the standard of performance under review." Id. at 95 . EPA added:

In this instance, it is reasonable for EPA not to promulgate performance standards for GHG emissions as part of this 8-year review cycle. We believe that the nature of GHG emissions renders them readily distinguishable from other air pollutants for which we have previously promulgated new performance standards concurrent with an 8-year review of the existing standards. Indeed, GHG emissions present issues that we have never had to address in the context of even an initial NSPS rulemaking for a source category. These differences warrant proceeding initially through a more deliberate process, i.e., the announced advanced notice of proposed rulemaking (ANPR), than in this source category-specific rulemaking.

Id. at 97-98. 
A third possibility would be for Congress to amend the CAA to authorize EPA to restrict, or authorize EPA to regulate, GHG emissions from electric power plants under an entirely new regulatory program. Such a step would not be unprecedented. When Congress amended the CAA in 1990, it created a new program to limit emissions of sulfur dioxide and oxides of nitrogen that contribute to acid deposition. ${ }^{87}$ The program applies primarily to coal-fired electric generating facilities, a principal source of those pollutants. ${ }^{88}$ The acid deposition control program includes a cap-and-trade program that allows regulated facilities to meet their regulatory obligations by purchasing emission allowances instead of by cutting their own emissions. ${ }^{89}$ Most of the bills introduced in Congress to deal with global climate change during the past few years have included a similar emissions trading program for $\mathrm{CO}_{2} \cdot{ }^{90}$

To date, EPA has not used any of the existing CAA regulatory mechanisms to regulate GHG emissions from stationary sources such as electric power plants, and Congress has not passed legislation mandating GHG emission reductions from electric generating facilities. ${ }^{91}$ Constraints on GHG emissions from those facilities have derived instead from state law.

87. 42 U.S.C. $\S \S 7651-76510$

88. See, e.g., id. $\S 7651 \mathrm{c}(\mathrm{e})$, Table A (listing particular facilities that qualify as "affected sources" for purposes of the acid deposition control provisions); id. § 7651d(a)(1) ("[E]ach existing utility unit ... is subject to the limitations and requirements of this section.").

89. See id. $\S 7651 \mathrm{~b}$ (describing the allowance program).

90. E.g., S. 485, 110th Cong. § 703 (2007); H.R. 4226, 110th Cong. §§ 121-146, 161-165 (2007); S. 843, 108th Cong. $\S 704$ (2003). Some of the legislation contains provisions specifically directed at electric generation units. See, e.g., S. 309, 110th Cong. § 708 (2007).

91. There is at least one other CAA regulatory program that might be used to address climate change. Section 112 creates a primarily technology-based regulatory program for stationary sources that emit hazardous air pollutants. Congress itself included in the statute a long list of air pollutants that qualify as hazardous. 42 U.S.C. $\S 7412$ (b)(1). $\mathrm{CO}_{2}$ is not on that list. EPA has the power to add pollutants to the statutory list. To do so, EPA must find that a pollutant

may present, through inhalation or other routes of exposure, a threat of adverse human health effects (including, but not limited to, substances which are known to be, or may reasonably be anticipated to be, carcinogenic, mutagenic, teratogenic, neurotoxic, which cause reproductive dysfunction, or which are acutely or chronically toxic) or adverse environmental effects whether through ambient concentrations, bioaccumulation, deposition, or otherwise. ...

Id. $\S 7412(\mathrm{~b})(2)$. This provision would appear to authorize EPA to list $\mathrm{CO}_{2}$ or other GHGs as hazardous air pollutants on the basis of a finding that they "may present ... a threat of . . . adverse environmental effects whether through ... bioaccumulation ... or otherwise." Id. The potential adverse health effects of $\mathrm{CO}_{2}$ are discussed infra at notes 388-97 and accompanying text. 


\section{State Regulation}

Despite (or because of) the federal government's failure to impose mandatory controls on GHG emissions from stationary sources, many states have taken steps to limit GHG emissions by electric generating facilities. State regulation has taken various forms. These include renewable portfolio standards requiring that power be produced from alternative energy sources that generate relatively low levels of GHG emissions. They also include regional or state-by-state limits on GHG emissions from stationary sources generally or from power plants in particular. These limits are often accompanied by emissions trading programs similar to the CAA's federal acid deposition control program. Recently, the tools used by the states to reduce emissions that contribute to climate change have expanded to include the denial of permits or licenses to coal-fired plants or the issuance of permits conditioned on actions to reduce the applicants' impact on climate change. ${ }^{92}$

\section{a. Renewable Portfolio Standards}

More than twenty states (although not Kansas) have enacted renewable portfolio standards ("RPS") as a means of minimizing reliance on traditional, carbon-laden fossil fuels to generate electricity. ${ }^{93}$ These standards are designed to increase the percentage of energy supplied by renewable resources. The standards typically require that a minimum percentage (which varies widely from state to state) of a utility's power plant capacity or generation come from renewable sources such as solar,

92. This article does not address the initiatives taken by the states to reduce GHG emissions from motor vehicles. For a more thorough assessment of the different approaches states have taken to address climate change, see Kirsten Engel, State and Local Climate Change Initiatives: What Is Motivating State and Local Governments to Address a Global Problem and What Does This Say About Federalism and Environmental Law?, 38 URB. LAw. 1015 (2006); Robert McKinstry, Jr. \& Thomas D. Peterson, The Implications of the New "Old" Federalism in Climate-Change Legislation: How to Function in a Global Marketplace When States Take the Lead, 20 PAC. MCGeorge Global Bus. \& DeV. L.J. 61 (2007).

93. See Rules, Regulations, and Policies for Renewable Energy, http://www.dsireusa.org/ summarytables/reg1.cfm? \&CurrentPageID $=7 \& E E=1 \& R E=1$ (illustrating the policies implemented in each state) (last visited Feb. 15, 2008); Pew CEnTER On Global Climate Change, StATES With RENEWABle PORTFOlio STANDARDS, http://www.pewclimate.org/what_is_being_done/ in the states/rps.cfm (briefly describing each state's legislation and approach) (last visited Feb. 15, 2008); see also J.R. DeShazo \& Jody Freeman, Timing and Form of Federal Regulation: The Case of Climate Change, 155 U. PA. L. REV. 1499, 1523 (2007) ("Legislatures in twenty-two states now require their electric utilities to generate some energy from renewable sources."). 
wind, or biomass. ${ }^{94}$ RPS programs can increase the role of renewable energy by increasing the required percentage over time. ${ }^{95}$ RPS programs often include a credit trading mechanism whose function is to provide flexibility in compliance options for utilities and to reward the efficient use of renewable energy technologies. ${ }^{96}$ As one source has noted, RPS standards "have the potential to... become effective levers for substantially reducing [GHG] emissions if the renewable portfolio percentage is set high enough. ... RPS measures can thus be integral to reducing [GHGs] in the long run, as an increased reliance on renewables will displace fossil fuels." 97

\section{b. Emission Controls and Cap-and-Trade Programs}

Probably the most prominent state program for controlling GHG emissions from the electricity sector is the Regional Greenhouse Gas Initiative ("RGGI") in which several northeastern and mid-Atlantic states are participating. That program mandates reductions in $\mathrm{CO}_{2}$ emissions from power plants, but it includes a cap-and-trade program that permits regulated utilities to comply with their reduction obligations by purchasing emissions credits from other regulated entities that exceed their mandated emissions cuts. ${ }^{98}$ The states participating in RGGI agreed to cap global warming emissions from the region's power plants at current levels and reduce them by $10 \%$ by $2019 .{ }^{99}$

Similarly, the governors of nine Midwestern states (including Kansas) in 2007 signed the Midwestern Regional Greenhouse Gas

94. Stephanie B. Oshita, The Scientific and International Context for Climate Change Initiatives, 42 U.S.F. L. REV. 1, 25 (2007); Barry G. Rabe, Mikael Román \& Arthur N. Dobelis, State Competition as a Source Driving Climate Change Mitigation, 14 N.Y.U. ENVTL. L.J. 1, 29 (2005).

95. Kirsten H. Engel \& Scott Saleska, Subglobal Regulation of the Global Commons: The Case of Climate Change, 32 ECOLOGY L.Q. 183, 218-19 (2005).

96. Inho Choi, Global Climate Change and the Use of Economic Approaches: The Ideal Design Features of Domestic Greenhouse Gas Emissions Trading with an Analysis of the European Union's $\mathrm{CO}_{2}$ Emissions Trading Directive and the Climate Stewardship Act, 45 NAT. RESOURCES J. 865, 934 n.308 (2005). According to DeShazo \& Freeman, "[o]ne important source of uncertainty concerns the prospects for markets in renewable energy credits. Although such markets promise to spur growth in renewable energy sources and to reduce compliance costs for utilities, this market is currently underdeveloped and trading is largely unregulated." DeShazo \& Freeman, supra note 93, at 1523 .

97. Engel \& Saleska, supra note 95, at 219 .

98. See Regional Greenhouse Gas Initiative-OVerview 1 (Dec. 16, 2005), http://www. rggi.org/docs/mou rggi overview_12 20 05.pdf (stating that the "program controls the right to emit ..., but allows companies to trade emissions permits").

99. CARBON BOOM, supra note 51, at 12. 
Reduction Accord ("The Accord"). ${ }^{100}$ The Accord commits the member states to the establishment of GHG reduction targets; development of a market-based and multi-sector cap-and-trade mechanism to help achieve those targets; the creation of a system to enable tracking, management, and crediting for entities that reduce GHG; and the development and implementation of additional steps as needed to achieve the reduction targets. ${ }^{101}$ The Accord also committed the members to the pursuit of cooperative regional initiatives designed to reduce GHG emissions, including the provision of electricity transmission adequacy to support new wind energy facilities; the creation of renewable fuels corridors and coordinated signage to promote renewable fuel usage across the Midwest; the use of advanced bioenergy permitting to assist states with the latest technologies; and the establishment of a low-carbon energy transmission infrastructure to supply the Midwest with "sustainable and environmentally responsible energy."

Individual states also have adopted GHG emission reduction requirements for stationary sources, including electric utilities. The California legislature adopted the path-breaking statute of this type, the Global Warming Solutions Act of 2006. ${ }^{103}$ The Act requires a reduction in GHG emissions statewide to 1990 levels by $2020,{ }^{104}$ and authorizes the California Air Resources Board to adopt technology-based emissions reduction regulations applicable to categories of sources, ${ }^{105}$ which are anticipated to include electric utilities. ${ }^{106}$ The statute also authorizes the Board to develop an emissions trading program, under which sources emitting fewer GHGs than their permits allow may sell emissions credits to sources exceeding their individual GHG caps. ${ }^{107}$

Some states have adopted specific statutory or regulatory GHG emissions caps for new power plants. Oregon's regulations ${ }^{108}$ offer new

100. Press Release, Midwest Governors Association, Governors Sign Energy Security and Climate Stewardship Platform and Greenhouse Gas Accord, http://www.midwesterngovernors. org/govenergynov.htm (last visited Feb. 19, 2008). This Web page links to the Accord itself, which was signed on November 15, 2007. The other nine signatories were the Governors of Wisconsin, Minnesota, Illinois, Indiana, Iowa, Michigan, Ohio, and South Dakota and the Premier of Manitoba, Canada. Id.

101. Id.

102. Id.

103. Cal. Health \& SafeTy Code $\S \S 38500-38599$ (West Supp. 2007). For discussion of the Act, see Alice Kaswan, The Domestic Response to Global Climate Change: What Role for Federal, State, and Litigation Initiatives?, 42 U.S.F. L. REV. 39, 53-58 (2007).

104. CAL. HEALTH \& SAFETY CODE $\S 38550$.

105. Id. §38560.

106. Id. § 38561(a).

107. Id. § 38570; see also Kaswan, supra note 103, at 55-58.

108. OR. ADMIN. R. 345-024-0550 (2003). 
power plants various options for meeting their reduction requirements, including the operation of certified cogeneration projects, the implementation of approved offset projects, or the payment of per ton offset fees. ${ }^{109}$ Washington state legislation mandates that new, large fossil fuel-fired electric generating facilities be subject to an approved $\mathrm{CO}_{2}$ mitigation plan that involves some combination of payments to third parties to provide mitigation, direct purchase of permanent carbon credits, and investment in applicant-controlled carbon dioxide mitigation projects, including cogeneration. ${ }^{110}$ Facility approval is subject to the requirement that $20 \%$ of the total $\mathrm{CO}_{2}$ emissions produced by the facility be mitigated. ${ }^{111}$ Even in states in which regulators have refused thus far to impose $\mathrm{CO}_{2}$ emission controls on proposed new coal-fired power plants, such as Montana, the need for and the inevitability of such controls in the future has been noted. ${ }^{112}$

In addition, some states, such as Massachusetts and New Hampshire, have established emissions caps for existing power plants. ${ }^{113}$ New Hampshire's Clean Power Act imposes annual limits through 2010 on emissions of $\mathrm{CO}_{2}$, as well as some criteria pollutants. Regulated plants may comply either by reducing their own emissions or purchasing emissions credits through a trading program approved by state regulators. ${ }^{114}$ The state environmental agency may approve off-site reduction measures such as carbon sequestration, shutdown of $\mathrm{CO}_{2}$ emitting sources, and electricity generation through renewable sources. ${ }^{115}$

109. DeShazo \& Freeman, supra note 93, at 1524.

110. WASH. REV. CODE ANN. § 80.70.020(2)-(3) (West 2001 \& Supp. 2007).

111. Id. § 80.70.020(4).

112. Southern Montana Elec. Generation and Transmission Cooperative, Permit \#3423-00, at 14 (May 11, 2007); Mike Dennison, Board Refuses CO2 Rules for Coal-Fired Power Plant, Missoulian, Jan. 12, 2008, at B1, available at http://www.missoulian.com/articles/2008/ 01/11/nes/mtregional/2news08.txt. The Montana permit proceedings are described more fully infra at note 381 .

113. DeShazo \& Freeman, supra note 93, at 1524. "Massachusetts became the first state to set a $\mathrm{CO}_{2}$ emissions standard for existing power plants when the Massachusetts Department of Environmental Protection adopted a multi-pollutant rule. The rule set new emissions standards for carbon dioxide, sulfur dioxide, nitrogen oxides, and mercury." Id. at $1524 \mathrm{n} .78$ (citing 310 MASs. CODE REGS. 7.29(1) (2004)).

114. Id. at 1524 (citing N.H. REV. StAT. ANN. §§ 125-O:3 to 125-O:4 (LexisNexis Supp. 2006)); see also Kevin L. Doran, Can the U.S. Achieve a Sustainable Energy Economy from the Bottom-Up? An Assessment of State Sustainable Energy Initiatives, 7 VT. J. ENVTL. L. 95, 104-05 (2006).

115. DeShazo \& Freeman, supra note 93, at 1524-25. 


\section{c. Refusals to Permit or Build Coal-Fired Plants}

Another development in state efforts to reduce the contribution of power plants to climate change is the denial by state regulators of permission to construct or operate such plants. The refusal of state legislative and regulatory bodies to allow certain kinds of electricity producing facilities is not unprecedented. ${ }^{116}$ Indeed, in at least one instance, a state adopted a sweeping moratorium on the construction of certain kinds of electric generating facilities. In 1976, the California legislature amended the Warren-Alquist Act to bar the construction of nuclear fission thermal power plants pending issuance by a state agency of a finding "that there has been developed and that the United States through its authorized agency has approved and there exists a demonstrated technology or means for the disposal of high-level nuclear waste." $" 117$ Because the federal Nuclear Regulatory Commission was in no position to approve such technology, either at the time the statute was amended or in the foreseeable future, the statute in effect amounted to a state-wide moratorium on the construction of nuclear power plants for the indefinite future. ${ }^{118}$ In 1983, the Supreme Court upheld the WarrenAlquist Act, holding that it was not preempted by the Atomic Energy Act. ${ }^{119}$

To date, no state has gone that far in restricting the development of coal-fired electric facilities. ${ }^{120}$ In 2007, however, three states denied

116. State public utility commissions have long refused to allow the construction of capacity that is not needed or refused to allow utilities to pass the costs of excess capacity on to the ratepayers. See Richard J. Pierce, Jr., Public Utility Regulatory Takings: Should the Judiciary Attempt to Police the Political Institutions?, 77 GEO. L.J. 2031, 2049 (1989) ("State utility commissions and state legislators have responded to the large rate increases requested to reflect these investments by denying utilities recovery of tens of billions of dollars in costs."). See generally Robert L. Glicksman, Allocating the Cost of Constructing Excess Capacity: "Who Will Have to Pay for It All?,” 33 U. KAN. L. REV. 429 (1985) (discussing issues relating to the construction of excess capacity at the Wolf Creek nuclear power facility in Kansas); Richard J. Pierce, Jr., The Regulatory Treatment of Mistakes in Retrospect: Canceled Plants and Excess Capacity, 132 U. PA. L. REV. 497 (1984) (discussing issues relating to large-scale energy projects which in hindsight would be considered mistakes).

117. CAL. PuB. RES. CODE $§ 25524.2$ (a) (West 2008).

118. See Peter Huber, Electricity and the Environment: In Search of Regulatory Authority, 100 HARV. L. REV. 1002, 1031 (1987) (stating that the moratorium was "precisely what California voters intended").

119. Pac. Gas \& Elec. Co. v. State Energy Res. Conservation \& Dev. Comm'n, 461 U.S. 190 (1983).

120. Federal legislators, however, have considered legislation that would prevent any plant using traditional coal-fired technology from proceeding. See, e.g., Moratorium on Uncontrolled Power Plants Act of 2008, H.R. 5575, 100th Cong., § 2(a) (2008) (prohibiting any permitting authority 
permits for coal-fired plants and in another state, plans to construct eleven new coal-fired plants were dramatically curtailed ${ }^{121}$ in light of the public outcry spurred by the original proposal. ${ }^{122}$ The regulatory climate for coal-fired power is clearly becoming more hostile at the state level. The remainder of this section describes the regulatory and political obstacles that prevented the construction of coal-fired plants in states such as Washington, Florida, North Carolina, and Texas in 2007. With these descriptions as background, Part III below analyzes in more depth KDHE's denial of the Sunflower applications.

i. Florida

The Florida Public Service Commission ("FPSC") in 2007 denied permission to construct a coal-fired power plant. ${ }^{123}$ Florida Power \& Light Company ("FPL") filed the petition for a determination of need for two electric power plants in Glades County. ${ }^{124}$ FPL proposed to put into service by 2013 and 2014 two ultra-supercritical pulverized coal ("USCPC") generating units with a combined net capacity of 1960 megawatts. ${ }^{125}$ The Florida Electrical Power Plant Siting Act ${ }^{126}$ ("Siting Act") is designed to balance increased demand for electric power with the broad interests of the public, including use of the state's natural resources. ${ }^{127}$ The Siting Act lists a series of factors that the FPSC must consider in deciding whether to approve a proposed new electric generating facility, without specifying the weight to be afforded each. ${ }^{128}$ The FPSC must take into account the need for electric system reliability and integrity, the need for adequate electricity at a reasonable cost, the

from issuing "a permit for a proposed new coal-fired electric generating unit under the Clean Air Act, unless the permit requires the unit to use state-of-the-art control technology to capture and permanently sequester carbon dioxide emissions from such unit"); see also Amanda Griscom Little, Let's Call the Coal Thing Off, GRIST, Mar. 9, 2007, http://www.grist.org/cgi-bin/printthis. pl?uri=/news/muck/2007/03/09/nocoal/index.html (describing a bill being drafted by Senator John Kerry).

121. See infra notes $123-77$ and accompanying text.

122. See Little, supra note 120 (stating that the groups "struck a truce" and agreed to "cut the number of new coal plants down to three").

123. In re Petition for Determination of Need for Glades Power Park Units 1 and 2 Electrical Power Plants in Glades County, by Fla. Power \& Light Co., Docket No. 070098-E1, Order No. PSC07-0557-FOF-EI, Order Denying Petition for Determination of Need, (July 2, 2007), available at http://www.psc.state.fl.us/library/filings/07/05350-07/05350-07.pdf [hereinafter Glades Power Decision].

124. Id. at 1.

125. Id.

126. Fla. STAT. ANN. $\S \S 403.501-403.518$ (West $2002 \&$ Supp. 2008).

127. Glades Power Decision, supra note 123, at 2 (citing FLA. STAT. ANN. $§ 403.502$ ).

128. Id. 
need for fuel diversity and supply reliability, and whether the proposed plant is the most cost-effective alternative available. ${ }^{129}$ In addition, the agency must consider the "conservation measures taken by or reasonably available to the applicant... which might mitigate the need for the proposed plant." 130 Finally, the Siting Act authorizes the FPSC to consider "other matters within its jurisdiction which it deems relevant." "131

The FPSC concluded that it was "in the public interest to deny FPL's petition for determination of need." 132 It found that the applicant failed to demonstrate that the proposed plants were the most cost-effective alternative available, taking into account the uncertainty associated with future natural gas and coal prices and with emerging energy policy decisions at both the state and federal level. ${ }^{133}$ In addition, the Commission relied on a 2005 amendment to the Siting Act which authorized the Commission to consider fuel diversity as a factor in determining need. ${ }^{134}$ The FPSC recognized the need for additional generation to meet current and future growth and declared that

uncertainty about cost-effectiveness alone will not necessarily control the outcome of every need determination decision. We find in this case, however, that the potential benefits regarding fuel diversity offered by FPL in support of the [proposed plants] fail to mitigate the additional costs and risks of the project, given the uncertainty of present fuel prices, capital costs, and current market and regulatory factors. ${ }^{135}$

The FPSC's decision was the first time it rejected a new power plant since 1992. ${ }^{136}$ The decision did not mention climate change or GHG emissions. Instead, it was couched vaguely in terms of uncertainty over fuel prices, capital costs, and unidentified "regulatory factors." Nevertheless, environmental concerns contributed to the outcome. FPL had claimed that the plants would have included filters, scrubbers, and other systems that would have cut $\mathrm{CO}_{2}$ emissions generated by the

\footnotetext{
129. Fla. StAT. ANN. $\S 403.519(3)$ (West $2002 \&$ Supp. 2008).

130. Id.

131. Glades Power Decision, supra note 123, at 2 (quoting Fla. StAT. ANN. $§ 403.519(3)$ ).

132. Id. at 4 .

133. Id.

134. Id.

135. Id. at 3-4.

136. Jim Ash, Commission Denies Coal Plant Near Everglades, Tallahassee Democrat, June 6, 2007, at $1 \mathrm{E}$.
} 
burning of coal by as much as $90 \%{ }^{137}$ Still, the plants would have emitted more mercury than any of FPL's existing plants. ${ }^{138}$ The fact that the plant would have been located in the middle of the Everglades also may have been a factor in the denial. ${ }^{139}$ Climate change also played a role. FPSC members indicated that they were concerned that the price of coal could become unstable if Congress decides to regulate GHGs. ${ }^{140}$ They also indicated that they regarded $\mathrm{CO}_{2}$ as well as mercury emissions as risks if the plant were approved. ${ }^{141}$ An environmental consultant testified before the FPSC that FPL could incur annual penalties for emitting $\mathrm{CO}_{2}$ between $\$ 120$ to $\$ 400$ million under climate change legislation being considered by Congress. ${ }^{142}$ Governor Charlie Crist had previously made it clear that he preferred that no new coal-fired power plants be licensed, ${ }^{143}$ and had issued an executive order requiring the adoption of standards to reduce greenhouse gas emissions from power plants to 2000 levels by 2017 and to 1990 levels by 2025 . $^{144}$

According to one account, the decision in the Glades Power Park case

mark[ed] the first time global warming has played a role in a PSC decision .... The PSC's decision was motivated by its belief that not building the plant would save customers huge costs, including the cost of cutting GHG emissions. The decision could be the harbinger of the PSC's approach to the five other proposals for new coal-fired power plants that are pending. ${ }^{145}$

The Executive Director of Associated Industries of Florida asserted that "[t]his idea that somehow this plant is going to help control climate

137. Curtis Morgan, FPL in Fight to Ease Doubts on Coal, Miami Herald, Feb. 11, 2007, at $1 \mathrm{~B}$.

138. Id.

139. See Ash, supra note 136 (Senator Lee Constantine from Altamonte Springs believed many factors contributed to this decision, but one factor was that the plant would have been "in the middle of the Everglades and we're spending billions of dollars to clean up the Everglades.").

140. Marc Caputo \& Curtis Morgan, FPL's Plan for 'Clean' S. Florida Coal Plant Rejected, MiAmi HERALD, June 6, 2007, at 1A.

141. Id.

142. Jim Ash, Consultant: Coal Plant an Expensive Mistake, TAllahasSEe Democrat, Apr. 18,2007 , at $4 \mathrm{~B}$.

143. See Letter to the Editor, Warning!, Coal Plants Face Rocky Road, TALlaHASSEE DEMOCRAT, June 7, 2007, at 2B (Governor Crist stating that "his preference is no coal period").

144. Fla. Exec. Order No. 07-127, §§ 1, 2(1) (2007), available at http://www.flgov. $\mathrm{com} / \mathrm{pdfs} /$ orders/07-127-emissions.pdf. According to one report, the state will need to retire or repower some of its older coal-fired power plants. DIRTY DOZEN, supra note 63, at 4.

145. David Hodas, Changing Course Towards an Energy-Efficient Future, 39 TRENDS No. 2, Nov./Dec. 2007, at 8. 
change for the world is a joke when China is putting up a power plant every day." "146 Nonetheless, FPL reacted to the decision by claiming that it was likely to decide to build more natural gas-fired plants to meet Florida's growing energy needs and to intensify its efforts to build one or two nuclear reactors. ${ }^{147}$

ii. Washington

Several months after the FPSC's decision, the State of Washington's Energy Facility Site Evaluation Council ("EFSEC") also refused to endorse a proposal to construct a coal-fired power plant. ${ }^{148}$ This time, the decision was based more explicitly on climate change-related concerns. Energy Northwest ("ENW") proposed to construct the Pacific Mountain Energy Center, a combined cycle 793-megawatt electrical generating facility which would operate on synthetic gas produced from petroleum coke, a byproduct of refining, or coal. According to the EFSEC, ENW's proposal was the first to involve an Integrated Gasification Combined Cycle ("IGCC") project with carbon sequestration. The agency described the project as involving "environmental technology that seeks to minimize carbon emissions, to recapture byproducts such as sulfur, and to utilize as its fuel, products such as petroleum coke, a refinery waste product that might otherwise not be recycled, and coal."

State legislation gave EFSEC the authority to recommend to the governor whether the state should enter into a site certification agreement that would authorize a power plant applicant to construct and operate the facility. ${ }^{150}$ About seven months after ENW filed its application, the legislature amended the statute to impose conditions on pending applications. ${ }^{151}$ In particular, the statute requires new facilities generating more than 1100 pounds of GHGs per megawatt hour of electricity to sequester GHGs to that level or below. ${ }^{152}$ Under the amended law, EFSEC must adopt criteria for evaluating an applicant's

146. Caputo \& Morgan, supra note 140.

147. Id.

148. In re Application No. 2006-01, Energy Nw., Pac. Mountain Energy Ctr. Power Project, Adjudicative Order No. 2, Council Order No. 833, Order: Staying Adjudicative Proceeding (Nov. 27, 2007), available at http:/www.efsec.wa.gov/FILES/orders/833\%20-\%20PMEC $\% 20$ stay $\%$ 20adjud.pdf [hereinafter Energy Northwest Decision].

149. Id. at 1.

150. Id. (citing WASH. REV. CODE $§ 80.50$ ).

151. Id.

152. Id. at 2 (citing WASH. REV. CODE $\S 80.80 .040(11)$ ). 
carbon sequestration plan, including but not limited to provisions requiring financial assurances sufficient to ensure successful implementation of the plan; geological or other approved sequestration commencing within five years of plant operation; monitoring the effectiveness of the implementation of the sequestration plan; penalties for failure to implement the plan on schedule; and the purchase of emissions reductions in the event of plan failure. ${ }^{153}$ The amended statute specified that an application pending on the date the law became effective (which only applied to the ENW application) include a carbon sequestration plan (or a GHG reduction plan, or GGRP) demonstrating how the project would satisfy these conditions, and that the applicant make a good faith effort to implement the plan. ${ }^{154}$ "Only after preparing a detailed sequestration plan, receiving a site certification agreement, and making a good faith effort to implement the plan, may an applicant who finds implementation 'not feasible' be excused from its terms and allowed to purchase greenhouse gas offsets." 155

ENW filed its GGRP in July 2007. It took the position that it was impossible to prepare a plan as contemplated by the statute due to the technological and economical infeasibility of geological sequestration. Instead, ENW proposed:

To prepare a specific plan in the future, perhaps as late as 2020 , when geological sequestration becomes a proven technology for use by power plants and a number of asserted technological, engineering, and legal questions have been answered. In the interim, ENW proposed to consider offsets based on assumptions that it enumerated in its GGRP. ${ }^{156}$

The issue before EFSEC was whether ENW's submission complied with the statute. It concluded unanimously that it did not, "that it is therefore insufficient as a matter of law, that its provisions cannot be supplemented to the level of minimal sufficiency by mere revisions, and that its flaws are pervasive and affect the processing of the entire application." 157 EFSEC therefore suspended the proceeding pending action by ENW to cure those flaws. According to EFSEC, the "basic flaw" in ENW's GGRP was that:

153. Id. n.2 (citing WASH. REV. CODE $\S 80.80(11)$ (a)-(f)).

154. Id. (citing WASH. REV. CODE $\S 80.80 .040(13)$ ).

155. Id. (citing WASH. REV. CODE $\S 80.80 .040(13)$ ).

156. Id. at $2-3$.

157. Id. at 4 . 
[I]t is not a plan at all in terms of the statute-it does not identify specific steps it will take to implement sequestration. Instead, it is a plan to make a plan, and it vows to begin making specific steps toward implementing geological sequestration at some future time, after geological sequestration becomes commercially accepted for use in reducing emissions of fossil-fueled power plants. It proposes that eventually, at some indefinite future time, it will seek to develop a specific plan for accomplishing the purposes of the statute. In the meantime, it argues,... it may purchase offsetting [GHG] emission rights from unspecified sources because a specific plan is futile and it need not make a good faith effort to comply with the letter of the statute. $^{158}$

EFSEC interpreted the statute as requiring an applicant to make "specific plans for specific actions to accomplish a specific goal,"159 sequestration of GHGs, and receive a Site Certification Agreement from the Governor. These requirements must be met

before [the applicant] can ask for relief by the purchase of offsets. Then, only after ENW has made a good faith effort to implement the plan, and only after [EFSEC] has agreed that implementation is "not feasible," may it be excused from compliance with plan implementation and allowed to purchase offsetting emission rights.

EFSEC rejected ENW's claims that compliance was futile, that it made a good faith effort to comply, and that the doctrine of impossibility should apply. ${ }^{161}$ ENW argued that its approach was a legitimate effort to engage in "adaptive management" by "allow[ing] details of compliance to be developed through different measures, over time, allowing learning from and improving upon compliance measures." ${ }^{\text {EF }}$ EFEC responded that the statute does not allow "adaptive management" to substitute for the

\footnotetext{
158. Id. EFSEC added:

The principal flaw in the GGRP is its failure to present a plan to achieve geological sequestration. It does not detail specific actions ENW will take. Instead, the GGRP merely states that because geological sequestration of power plant emissions is not a conventional technology, and because uncertainties exist in technical and legal aspects of geological sequestration, it will not begin to prepare a specific plan until technical and legal questions are resolved. In this regard, ENW's GGRP fails to meet the plain language of the statute - it is a plan to prepare a plan at some indefinite later date.

161. Id. at 7. EFSEC also concluded that ENW failed to meet the financial assurances, monitoring, and penalty identification requirements of the statute, and that the GGRP did not include the required provisions for purchase of emissions reductions. Id. at 6 .

162. Id. at 7 .
} 
specific statutory requirements. Further, it disagreed that ENW's GGRP qualified as adaptive management, a decisionmaking process which pursues specific goals through clearly identified means. Instead, the GGRP was "a proposal to develop goals and measures later."163

About a month after EFSEC stayed further processing of ENW's application, it clarified that its decision was "a temporary, interim measure," and that it would resume processing the application when ENW corrected the deficiencies identified in the order. ${ }^{164}$ ENW claimed that operation of the proposed plant using natural gas power would comply with state emission requirements. Accordingly, EFSEC should not "quibble about the sequestration plan." 165 EFSEC responded that ENW's application was for an IGCC facility with sequestration, using natural gas as a backup fuel. EFSEC could not certify the project as an IGCC plant because ENW failed to comply with the sequestration plan requirements. "If ENW wants to propose a natural gas plant with prefitting for possible later IGCC operation, based on a future application for that purpose, it is free to amend its application to do so."166

The ENW decision, like the FPL decision, rejected a utility's plans to put into service a new coal-fired power plant. The FPL decision rested primarily on matters traditionally considered by state utility commissions - the cost of service to be supplied by the plant if approved-although a recent statutory amendment relating to fuel diversity played a part. The FPSC rested its decision on the uncertainty attributable to the impact of unspecified "regulatory factors," a veiled reference to the cost of compliance with future federal or state climate change regulation. ${ }^{167}$ The ENW decision was based squarely on the potential environmental impact of unsequestered $\mathrm{CO}_{2}$ emissions. EFSEC's decision responded to a set of statutory requirements enacted to deal specifically with ENW's proposed plant. Although it provides another example of the increasing regulatory obstacles facing proposed new coal-fired power plants, it is likely to have little value as precedent in licensing decisions in a state (such as Kansas) lacking the kind of statutory sequestration requirements in effect in Washington.

163. Id.

164. In re Application No. 2006-01, Energy Nw., Pac. Mountain Energy Project, Council Order No. 835 (Wash. Energy Facility Site Evaluation Council Dec. 21, 2007) (Clarifying Order), at 2, available at $\mathrm{http}: / / \mathrm{www} . e f s e c . w a . g o v / p m e c . s h t m l$.

165. Id. at 4 .

166. Id.

167. See supra notes $69-115$ and accompanying text. 


\section{iii. North Carolina}

North Carolina energy regulators in 2007 took a less absolute approach than the refusals to license new coal-fired power plants reflected in the Florida and Washington decisions. In 2005, Duke Energy sought a certificate of public convenience and necessity allowing it to construct two new 800-megawatt coal-fired electric generating facilities, along with related transmission facilities. ${ }^{168}$ In March 2007, the state utilities commission granted the certificate, but only in part, and subject to conditions. The commission concluded that the public convenience and necessity supported the construction of only one plant. The certificate was conditioned, however, on the retirement by Duke of four existing units at the site of the new plant. In addition, the commission required Duke to invest $1 \%$ of its annual retail electricity revenues in energy efficiency and demand reduction programs. Finally, the agency required Duke to retire older coal-fired units (in addition to the four existing units at the proposed new plant site) on a megawatt-bymegawatt basis, after considering the impact on reliability. The utilities commission explained that its decision would "allow Duke to increase its baseload generating capacity without significantly increasing its environmental footprint." 169

Duke had considered the use of IGCC technology, which the commission described as "an emerging coal technology that causes less pollution than other forms of coal-fired generation." ${ }^{\text {"170 }}$ The commission concluded that Duke could not rely on IGCC technology to supply its short-term need for additional generating capacity because IGCC units had not yet been constructed as a large-scale electric generating resource. It also found that "a cost effective method for carbon sequestration is, at best, an unresolved issue" and that it was unclear whether IGCC would operate as effectively as its proponents claim. ${ }^{171}$ The agency reasoned that approval of only one new generating unit, instead of the two sought by Duke, would allow more time for IGCC technology to develop before Duke needed to build more baseload capacity. "Approving one unit now," the commission concluded, "together with the retirement of older,

168. In re Duke Energy Carolinas, LLC, Docket No. E-7, Sub 790 (N.C. Util. Comm'n Mar. 21, 2007) (Order Granting Certificate of Public Convenience Necessity with Conditions), available at http://ncuc.commerce.state.nc.us/cgibin/webview/senddoc.pgm?dispfmt=\&itype=Q\&authorization= \&parm2=ZAAAAA08070B \&parm3 $=000123542$.

169. Id. at 9 .

170. Id. at 25 .

171. Id. at 27 . 
coal-fired units, limits Duke's carbon footprint and serves as a hedge against the prospect of carbon regulation." ${ }^{\text {"72 }}$ Thus, even though the commission acknowledged that the abundance of domestic supplies of coal as compared to natural gas makes "coal a more attractive choice for baseload generation," 173 it took a go-slow approach due to the contribution of coal-fired power to the problems associated with climate change. The commission did so even though the factors relevant to the issuance of a certificate of convenience and necessity, at least as described by the commission, do not explicitly include environmental impact, no less impact on climate change. ${ }^{174}$ In the wake of the decision, Duke indicated that it was reassessing its plans. ${ }^{175}$ The Division of Air Quality of the North Carolina Department of Environment and Natural Resources subsequently approved an air quality permit for the new coalfired boiler, provided Duke shuts down four older units and identifies additional $\mathrm{CO}_{2}$ offsets to mitigate the new unit's $\mathrm{CO}_{2}$ emissions and achieve carbon neutrality by $2018 .^{176}$

The North Carolina decision is noteworthy for at least two reasons. First, like EFSEC's decision, the state agencies relied explicitly on their desire to minimize the contribution of electricity generation to climate change, notwithstanding the fact that GHGs were not being regulated under state law. ${ }^{177}$ Second, unlike the FPSC and EFSEC decisions, the disposition of the North Carolina permit application did not rest on recent legislation designed, explicitly or otherwise, to deal with climate change. The state utilities commission instead rested its decision on more general legislative criteria not adopted with climate change in mind.

iv. Texas

In a fourth situation that came to a head in 2007, ambitious plans for the construction of a series of coal-fired power plants were severely

\footnotetext{
172. Id. at 33 .

173. Id. at 29 .

174. Id. at 7 (citing N.C. GEN. STAT. § 62-110.1).

175. See Little, supra note 120.

176. Press Release, N.C. Dep't of Env't and Natural Res., Office of Public Affairs, Revised Air Permit Approved for Duke Power Plant, (Jan. 29, 2008), available at http://www.enr. state.nc.us/html/news_releases.html.

177. See Statement of William G. Ross Jr., Secretary, N.C. Dep't of Env't and Natural Res., (Jan. 29, 2008), available at http://www.enr.state.nc.us/html/news_releases.html (stating that the Duke permit requires implementation of a $\mathrm{CO}_{2}$ mitigation plan to make the facility carbon neutral by 2018 "[a]though carbon emissions are not yet regulated").
} 
curtailed before they ever got off the drawing board, in part because of the $\mathrm{CO}_{2}$ emissions that the plants would have generated. In April 2006, the TXU Corporation announced that it would build eleven new coalfired power plants. Texas Governor Rick Perry tried to fast-track issuance of permits for the eleven plants. ${ }^{178}$ The project quickly generated opposition, however. TXU's chief executive neglected to curry favor with consumers, community groups, or state legislators, who either doubted the need for the additional generating capacity or feared that the plants would result in increased electricity prices. ${ }^{179}$ Environmental groups objected not only because of the plants' impact on local pollution, but also because of their contribution to climate change. The eleven new plants would have generated seventy-eight million tons of $\mathrm{CO}_{2}$ annually, adding to the carbon emissions that already made Texas the nation's largest $\mathrm{CO}_{2}$ emitter. ${ }^{180}$ When some of TXU's shareholders complained about the carbon footprint the plants would create, the chief executive reacted dismissively. He responded that Congress was not likely to regulate GHGs in the near future and that, even if it did, TXU could retrofit the plants to curtail emissions. ${ }^{181}$

The company's rejoinder did not assuage the concerns of those opposed to the plants on environmental grounds, and the company's share price fell. By the summer of 2006, "TXU had become a national symbol of a carbon dioxide emitter." 182 When Dallas mayor Laura Miller organized a coalition of Texas cities to intervene in TXU's coal plant hearings, TXU became convinced that the original plan to build eleven plants was doomed. ${ }^{183}$ In November 2006, Texas Pacific Group, Kohlberg Kravis Roberts \& Co., and Goldman Sachs approached TXU about buying the company for $\$ 45$ billion and taking it private. The prospective buyers asked William Reilly, the Administrator of the federal $1 \mathrm{~A}$.

179. Elizabeth Souder et al., Missteps Led up to TXU Deal, Dallas Morning News, Mar. 9, 2007, http://www.dallasnews.com/sharedcontent/dws/bus/industries/energy/stories/030407dnbustxu. 3b59709.html.

180. Marc Gunther, TXU Faces a Texas Coal Rush, FORTUNE, Feb. 5, 2007. "TXU is fighting not just the usual activists from the Sierra Club and Public Citizen but environmental groups like Environmental Defense and the Natural Resources Defense Council, which are ordinarily businessfriendly. (With GE, DuPont, and others, they formed the coalition of big companies to lobby for carbon caps.)" Id.

181. Souder et al., supra note 179.

182. Id. See also Elizabeth Souder, TXU to Take Buyout, DALlas MoRnING News, Feb. 26, 2007, 1A, available at http://www.dallasnews.com/sharedcontent/dws/bus/industries/energy/ stories/022607bustxusale.e4la46.html (describing the original TXU plan as "a symbol of global warming nationally, as Congress debates whether to place limits on [GHG] emissions").

183. Souder et al., supra note 179. 
EPA during the first Bush presidency and a vice president of Texas Pacific Group, to help negotiate the deal. ${ }^{184}$

Reilly negotiated an agreement with two major environmental groups-Environmental Defense and the Natural Resources Defense Council - under which the groups agreed to drop pending lawsuits to block construction of the plants and support the buyout. ${ }^{185}$ In return, the TXU buyers agreed to build only three of the eleven coal plants originally proposed, to cut electricity prices, to reduce emissions of regulated air pollutants by $20 \%$, to reduce $\mathrm{CO}_{2}$ emissions to 1990 levels by 2020 , and to support legislation restricting GHG emissions. ${ }^{186}$ In addition, the buyers promised to consider the use of coal gasification technology for future plants, which would allow the capture and storage of $\mathrm{CO}_{2}$ when sequestration technology is more fully developed. ${ }^{187}$ TXU's chief executive admitted that public opposition to the plant was one reason he made the deal. The buyers also would pursue more wind power and double the amount spent on energy efficiency programs to $\$ 80$ million for the next five years. ${ }^{188}$ In February 2007, TXU's Board of Directors agreed to sell the company. ${ }^{189}$ The company agreed not to propose building any traditional, pulverized coal plants outside of Texas, despite plans to do so in the Northeast. ${ }^{190}$ It subsequently announced plans to more than double its current purchase of wind power and to invest $\$ 400$ million in conservation programs and incentives for consumers to lower use during peak hours. TXU also indicated that it would reopen several natural gas plants.

The implications of the TXU deal for the future of coal-fired power apparently were not confined to Texas. The regional director of Environmental Defense characterized the agreement as "a watershed moment in America's fight against global warming."191 Environmental groups generally viewed the TXU agreement as sending a signal to other power companies considering the development of coal-fired plants nationwide that public and political opinion had turned against coal and

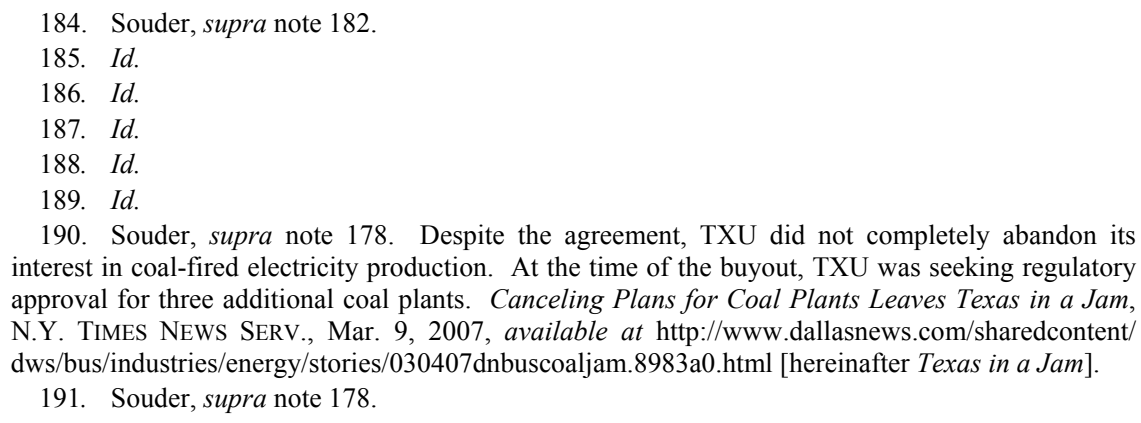
interest in coal-fired electricity production. At the time of the buyout, TXU was seeking regulatory approval for three additional coal plants. Canceling Plans for Coal Plants Leaves Texas in a Jam, N.Y. Times News SeRV., Mar. 9, 2007, available at http://www.dallasnews.com/sharedcontent/ dws/bus/industries/energy/stories/030407dnbuscoaljam.8983a0.html [hereinafter Texas in a Jam].

191. Souder, supra note 178. 
that "shareholders might now see old-style coal plants as an unacceptable risk." 192 These predictions seemed pretty close to the mark. Subsequent to the TXU deal, utilities in several other states cancelled plans for new coal-fired electric facilities, ${ }^{193}$ and coal-fired plants in other jurisdictions were opposed on the basis of the impact they would have on climate change. ${ }^{194}$ The hostile reception generated by plans to build new coalfired plants increased investors' interest in natural gas, renewable, and nuclear energy sources. ${ }^{195}$

\section{v. Other States}

Recent proposals to build coal-fired power plants in other states also have foundered. Although the decisions in these states restricting the ability of utilities to rely on coal-fired power have been based primarily on need rather than environmental factors, regulators have also expressed concern over the GHGs emitted by coal-fired electricity generation. ${ }^{196}$

192. Randy Lee Loftis \& Elizabeth Souder, Studying All Sides of TXU's Sale: Coal Plant Controversy Not Going Away, DALLAS MoRnING News, Feb. 27, 2007 at 1A.

193. Albert Raboteau, To Dismay of Power Utilities, Coal Emissions Are Under Fire, ROANOKE TiMES, July 29, 2007, at A10 (stating that plans for new coal-fired plants had been cancelled in eight states in the previous year).

194. See, e.g., Greg Edwards, Dominion Coal May Send Rates Up, Richmond TimesDispatch, July 17, 2007, at B7 (proposed 585-megawatt power plant which would include equipment to capture $\mathrm{CO}_{2}$ emissions when the equipment becomes commercially available); Michael Sluss, Coalition Opposes Power Station, ROANOKE TIMES, Sept. 26, 2007, at A1 (describing campaign by environmental groups to block the Dominion Virginia Power proposed plant in part based on its $\mathrm{CO}_{2}$ emissions).

195. Texas in a Jam, supra note 190 .

196. Virginia regulators, for example, objected to or sought to modify plans for coal-fired facilities thought to involve excessive $\mathrm{CO}_{2}$ emissions. See Greg Edwards, Plant Also Concerns SCC, RiCHMOND TIMES-DiSPATCH, Dec. 1, 2007, at B9 (reporting that State Corporation Commission staff concluded that Dominion's proposed plant did not qualify as carbon-capture compatible); Rex Springsteen \& Rex Bowman, Panel Wants Cleaner-Burning Plant, Richmond Times-DisPatch, Dec. 1, 2007, at B9 (describing request by Virginia's Air Pollution Control Board that Dominion Virginia Power reduce the 5.3 million tons of $\mathrm{CO}_{2}$ it would emit annually under its current design). The Virginia State Corporation Commission ultimately approved the plant, but, as of this writing, the plant still needed approval from the Virginia Air Pollution Control Board. Greg Edwards, SCC Approves Coal Plant: Dominion Va. Power Proposes Building a Plant in Wise County, RiCHMOND TiMES-DisPatCH, Apr. 1, 2008. Two weeks after its action in the Dominion matter, however, the Commission rejected a proposal by American Electric Power to build a $\$ 2.23$ billion clean coal plant in West Virginia on the ground that the utility's cost estimate was not credible. The Virginia Commission's approval was needed because the utility's Virginia customers would have had to pay for the plant's construction. See Va. Halts Plans for Neighboring Plant, GrEENwIRE, Apr. 15, 2008, http://www.eenews.net/

Greenwire/2008/04/15/archive/6?terms=virginiathalts. The West Virginia Public Utility Commission had previously granted a certificate of public convenience and necessity for the plant. AEP Receives Approval to Build IGCC Plant from WV PSC, available at http://www.aep. $\mathrm{com} /$ newsroom/newsreleases/default.asp?dbcommand=displayrelease \&ID=1440. 
The Oregon Public Utility Commission ("OPUC") rejected a bid by PacifiCorp to build two new coal-fired power plants on the ground that the utility failed to justify the need for that much baseload capacity. In addition, the agency concluded that the proposal to build a combined 1109 megawatts of new coal-fired generation was inconsistent with the utility's own OPUC-approved plan to focus on conservation, renewable resources, and demand-side measures to meet electricity demand. ${ }^{197}$ According to one Commissioner, OPUC "really skated on the $\mathrm{CO}_{2}$ issue in this ruling." "198 But OPUC stated that it expected the utility to explore "bridging strategies" that would allow it to delay a commitment to coal until cleaner technologies, such as IGCC, become commercially feasible. ${ }^{199}$ In addition, regulators viewed skeptically PacifiCorp's plan to sell surplus power to customers in other states in light of the aversion to coal-fired generation in those states. OPUC noted, for example, that California had recently limited imports of coal-fired power from other states to plants whose emissions are comparable to natural gas-fired plants. $^{200}$

State regulators have also wounded proposed coal-fired projects more indirectly. In late 2007, the Minnesota Public Utilities Commission ("MPUC") refused to require Xcel Energy to buy power from a 600megawatt coal-fired power plant proposed by Excelsior Energy. ${ }^{201}$ The MPUC had declared just a few months earlier that it would consider requiring a number of utilities to enter power-purchase agreements with the proposed plant, which would have been an "innovative" coalgasification facility potentially capable of capturing its $\mathrm{CO}_{2}$ emissions. ${ }^{202}$ It cited growing disillusionment with coal, assurances from Xcel that it did not need the additional power, and the high cost to Xcel's customers

197. Brian Wingfield, Oregon Regulators Frown on Big Coal Push by PacifiCorp, 35 ENERGY DAILY No. 11, Jan. 18, 2007.

198. Steve Hooks, PUC Turns Down PacifiCorp Coal-Fired Proposals, EnERgY Trader, Jan. 18,2007 , at 4 .

199. Id.; see also Gail Kinsey Hill, PacifiCorp's Coal Proposal Bites the Dust at the PUC, PORTLAND OREGONIAN, Jan. 17, 2007, at D1 (noting that the "alternate strategy would allow PacifiCorp to delay a commitment to coal until a cleaner technology, known as integrated gasification, could be developed and commercialized").

200. Wingfield, supra note 197. The Executive Director of the Oregon Citizens' Utility Board characterized coal plants as "tremendously risky," and anticipated "significant regulation of carbon emissions" in the future. Dave Anderton, Doubts Cloud Coal-Plant Plan, Desert Morning News, Feb. 7, 2007, at E4.

201. H.J. Cummins, PUC Cools to the Idea of a "Clean Coal" Plant, MinnEAPOLIS-ST. PAUL StAR TriB., Nov. 2, 2007, at 1D; IGCC Rides a Regulatory Seesaw, 111 POWER ENG'G 28, Nov. 2007; PUC Rejects Iron Range Power-Plant Project, St. PAUl PIONEER PRESS, Nov. 2, 2007, at C2.

202. IGCC Rides a Regulatory Seesaw, supra note 201. 
of the proposed plant's output as reasons for refusing to compel Xcel to purchase power from the proposed plant. ${ }^{203}$

The Chairman of the MPUC described the regulatory environment for coal-fired power plants as having undergone a "paradigm shift," noting the delay or cancellation of coal-gasification projects in several other states. $^{204}$ It was in the context of this increasingly hostile regulatory atmosphere that KDHE addressed the coal-fired units proposed for Holcomb, Kansas in the fall of 2007.

\section{Climate Change AND the Holcomb Plants}

Despite the absence of federal regulation restricting GHG emissions from stationary sources, many states, individually or collectively, have taken steps to minimize the contribution to global climate change of coal-fired electric generating facilities, one of the largest sources of $\mathrm{CO}_{2}$ emissions. These efforts have included renewable portfolio standards designed to increase the slice of electric power derived from renewable or low-carbon fuels, emissions reduction requirements applicable to broad categories of stationary sources or to power plants in particular, cap-and-trade programs, and carbon sequestration requirements. Each of these approaches has the potential to make it difficult if not impossible for utilities to pursue plans to enhance generating capacity by operating facilities that burn coal to produce electricity.

Kansas has resorted to none of these regulatory devices. Yet, the KDHE's October 2007 decision on the Sunflower Electric Power Corporation's bid to build two new coal-fired generators places Kansas among the states that have denied permission to construct coal-fired power plants on the basis of the $\mathrm{CO}_{2}$ emissions these plants generate. KDHE either could not or chose not to base its denial of the Sunflower applications on the grounds that formed the basis of the decisions by Florida and Washington regulators to reject coal-fired power plant applications. KDHE might have relied on the uncertainty of the cost of coal-fired power resulting from emerging federal and state energy and environmental policies that the FPSC cited in denying FPL's

203. See PUC Rejects Iron Range Power-Plant Project, supra note 201; Cummins, supra note 201

204. Cummins, supra note 201. In other states, regulators have recently approved of plans to construct coal-fired power plants. See, e.g., Ruling Allows Two Elk Plant Construction to Proceed, TRIB.COM, Mar. 3, 2008, http://www.trib.com/articles/2008/03/04/news/wyoming/0422dd8d67 c003f987257400001dca2b.txt. 
application. ${ }^{205}$ KDHE could not have cast its decision along the lines of EFSEC's denial of ENW's application because Kansas lacks a statute mandating the formulation and implementation of carbon sequestration plans. $^{206}$ Instead, KDHE based its denial of the Sunflower application directly on the adverse impacts on public health and the environment that construction of the Holcomb generators would cause by virtue of their $\mathrm{CO}_{2}$ emissions. $^{207}$

The legal basis for KDHE's decision was quickly challenged. Some members of the state legislature claimed that, because KDHE's decision was not authorized by statute, the decision gave rise to separation of powers concerns. ${ }^{208}$ One representative argued that the decision "is not based upon any statutory authority. It is an arbitrary decision.... And the legislative branch of government has a decision to make: Do we stand by and let the executive branch make up the rules or do we reassert our power?"209

This Part describes the Sunflower application, the Kansas Attorney General's Opinion that addressed KDHE's authority to consider the climate change impacts of the Holcomb units, the KDHE staff recommendation, KDHE Secretary Bremby's decision denying permission to build those units, and the reactions that Bremby's decision prompted among opponents and supporters of the proposed Holcomb units. Relying on an interpretation of the relevant statutory text and its evolution and on case law interpreting analogous provisions of the federal pollution control statutes, Part IV concludes that existing statutes vest KDHE with the authority to deny applications for coal-fired power plants on the basis of their projected contribution to climate change.

\section{A. The Holcomb Application}

Sunflower sought permission in February 2006 to build coal-fired generators in Holcomb, Kansas, adjacent to its existing Holcomb coalfired generator. ${ }^{210}$ Sunflower's original plans included three steam generating units, but the utility requested in June 2007 that KDHE

\footnotetext{
205. See supra notes $132-44$ and accompanying text.

206. See supra notes $151-55$ and accompanying text.

207. See infra notes $258-70$ and accompanying text.

208. John Taylor, Rep. Expects 'Huge Fight' Over Coal Plants, LAWRENCE J.-WoRLd, Jan. 5, 2008 , at $1 \mathrm{~B}$.

209. Id. (statement of Rep. Kenny Wilk).

210. KDHE StAFF RESPONSIVENESS SUMMARY, supra note 3, at 1 .
} 
remove one of the generating units from consideration. ${ }^{211}$ Each new unit would have been a super-critical 700 megawatt, pulverized coal-fired boiler. $^{212}$ They would have burned Powder River Basin low-sulfur, subbituminous coal as primary fuel and natural gas as a backup. ${ }^{213}$ The utility's existing coal, lime, and ash handling equipment would have been altered to double throughput capability. ${ }^{214}$ The utility planned to add two new cooling towers and two emergency generators. ${ }^{215}$

The plants were designed by Sunflower to be part of a "bio-energy center" that would include an ethanol plant and a facility to use an experimental algae process to capture $\mathrm{CO}_{2}$ emissions from the generating units. $^{216}$ The two units had the potential to emit eleven million tons of $\mathrm{CO}_{2}$ annually. ${ }^{217}$ According to Sunflower, however, the bioenergy center would have cut the plants' $\mathrm{CO}_{2}$ emissions to 3.6 million tons a year. ${ }^{218}$

The application prompted opposition on a variety of grounds. One complaint derived from Sunflower's plans to export much of the power produced by the two new units. The electricity produced by the two units would have been shared by sixty-seven cooperatives located in Kansas and neighboring states. ${ }^{219}$ One unit would have supplied power to Kansas. The other would have been owned by a rural cooperative, Tri-State Generation and Transmission Association, and would have provided electricity to eastern Colorado. ${ }^{220}$ According to Governor Sebelius, only $15 \%$ of the proposed plants' electric output would have been consumed by Kansans; the rest would have been exported to users in Texas and Colorado. ${ }^{221}$ These facts fueled concern that most of the adverse effects resulting from the plant's operation would be borne by

\footnotetext{
211. Id.

212. Id.

213. Id.

214. Id

215. Id.

216. Mufson, supra note 5; see also Stephen R. Morris \& Melvin Neufeld, Sebelius' Rejection of Permits Is Disastrous, KAN. CITY STAR, Nov. 11, 2007, at B10 (stating that the integrated bioenergy center would have included a biodiesel and ethanol plant, an anaerobic digester, a dairy farm, and a microalgae reactor, which would have used $\mathrm{CO}_{2}$ to grow algae for renewable fuels production, and that the technology "would have rendered the expansion nearly carbon neutral").

217. Utility Sues Over Coal-Plant Denial, Wichita EAgLe, Nov. 17, 2007, at $1 \mathrm{~B}$.

218. See id. ("Sunflower estimated the bioenergy center would have cut the coal plants' carbon dioxide emissions from 11 million tons a year to 3.6 million tons.").

219. Wald, supra note 11.

220. Tri-State is subject to a renewable portfolio standard in Colorado which requires that it use renewable energy sources to meet $10 \%$ of its sales. It currently uses less than $1 \%$ renewable resources and two-thirds of its power comes from coal. Mufson, supra note 5.

221. Rejection, supra note 65, at 2364.
} 
Kansans, while the new generating capacity would largely benefit consumers in other states.

Environmental groups claimed that the technology envisioned for use at the bioenergy center was too experimental to be a reliable means for minimizing the plants' $\mathrm{CO}_{2}$ emissions. ${ }^{222}$ The attorneys general of eight eastern states reacted to the Holcomb application in similar fashion. ${ }^{223}$ They requested that KDHE not issue the permit "unless Sunflower designs the plant in a way that minimizes the generation of $\left(\mathrm{CO}_{2}\right)$ emissions and/or allows the capture of such emissions." ${ }^{, 24}$ All eight states had made reduction of $\mathrm{CO}_{2}$ emissions a priority, but, according to the attorneys general,

the annual emissions from the Holcomb plant extension would cancel out all the emissions reductions resulting from the RGGI. With a lifetime of more than 60 years, the Holcomb units, if built as proposed, might well emit more than one billion tons of $\mathrm{CO}_{2}$ in total, thus significantly contributing to the public health and environmental damage associated with global warming.

The letter also argued that state and federal laws required issuance of a CAA permit by KDHE to Sunflower before construction on Holcomb could begin. ${ }^{226}$ Because the plants would be located in an area in compliance with the CAA's national ambient air quality standards, Sunflower had to show, before KDHE could issue a permit to it, that the units would use the best available control technology ("BACT"). ${ }^{227}$ The attorneys general asserted that the CAA required the use of "innovative fuel combustion techniques' to achieve the 'maximum degree of

222. High Court Takes on Coal Appeals, Wichita EAgLE, Nov. 30, 2007, at 3B.

223. Letter to Kansas Department of Health and the Environment, Rick Bolfing, from attorneys general of eight other states, Comments Regarding Proposed Holcomb Station Expansion Air Quality Construction Permit (Dec. 15, 2006), available at http://www.kdheks.gov/ download/States Atty_General Letter 12.15.2006.pdf [hereinafter State AGs Letter].

224. Id. Attorneys general of states in the northeast and California have submitted similar letters urging agencies responsible for ruling on air quality permits in other states to limit $\mathrm{CO}_{2}$ emissions from coal-fired power plants. See, e.g., Letter from Edmund G. Brown, Jr., et al., to Joseph C. Eller, S.C. Department of Health and Environmental Control (Jan. 22, 2008) (on file with author) [hereinafter Brown Letter] (urging South Carolina environmental agency to refuse to issue permit to proposed new 1320 megawatt coal-fired power plant unless it is designed to minimize $\mathrm{CO}_{2}$ emissions or allow for the capture and secure sequestration of those emissions).

225. State AGs Letter, supra note 223, at 2.

226. Id. at 3 .

227. See 42 U.S.C. $\S 7475(a)(4)$ (2000) (prohibiting the construction of any new or modified major emitting facility in a "prevention of significant deterioration" (PSD) area unless the facility is subject to the best available control technology). PSD areas are those with ambient concentrations of the CAA's criteria pollutants that are lower than required by the national ambient air quality standards. Id. $\S \S 7407(\mathrm{~d})(1)(\mathrm{A}), 7471$. 
reduction for each pollutant subject to regulation' under the [CAA]."228 They claimed that the CAA's legislative history indicates that Congress intended that BACT analysis include "the full range of production methodologies," including IGCC, which they characterized as "an established and available production process."229 The attorneys general also charged that KDHE "must consider the energy, environmental, and economic impacts of each unit as part of its BACT analysis." ${ }^{230}$ They added that, even if the increased $\mathrm{CO}_{2}$ emissions resulting from the proposed Holcomb units might not require their own BACT analysis as "regulated pollutants" under EPA's interpretation of the CAA, 231 the "detrimental environmental effects of these emissions" had to be considered under the "environmental impacts prong of BACT." 232

\section{B. The Attorney General's Opinion}

Recognizing that a rejection of the Sunflower application based on its effect on climate change would be without precedent in Kansas, KDHE solicited an opinion from the state's Attorney General on the legality of a denial of the application on those grounds. The Attorney General responded in an Opinion dated September 24, 2007.233 According to the Opinion, the question posed was

228. State AGs Letter, supra note 223, at 3. See also 42 U.S.C. § 7479(3) (defining best available control technology, in part, as "an emission limitation based on the maximum degree of reduction of each pollutant subject to regulation under [the CAA] emitted from or which results from any major emitting facility, which the permitting authority... determines is achievable for such facility through application of ... innovative fuel combustion techniques for control of each such pollutant"). KDHE's staff concluded that the units proposed by Sunflower required a PSD permit "because one or more of the [PSD] regulated air pollutants from the proposed activity exceeds the significance level(s)." KDHE STAFF RESPONSIVENESS SUMMARY, supra note 3, at 2. According to the staff,

BACT applies to each new or modified . . . emissions unit . . . for each pollutant having a potential to emit, or an increase in potential to emit, above the PSD significance level(s). For the proposed Sunflower generating units, the increase in potential-to-emit is above the PSD significance level for $\mathrm{NO}_{\mathrm{x}}, \mathrm{SO}_{2}, \mathrm{CO}, \mathrm{PM} / \mathrm{PM}_{10}$, sulfuric acid mist, lead, and VOCs and was reviewed under the PSD regulations.

Id. at 3. The staff recommendation identified BACT for oxides of nitrogen, carbon monoxide, sulfur dioxide, volatile organic compounds, particulate matter, lead, and sulfuric acid, id., but not for $\mathrm{CO}_{2}$.

229. State AGs Letter, supra note 223, at 3 (citing 123 Cong. Rec. 18472 (1977)).

230. Id ; see also 42 U.S.C. $§ 7479(3)$ (defining best available control technology to require permitting agency to " $\operatorname{tak}[\mathrm{e}]$ into account energy, environmental, and economic impacts and other costs").

231. At the time, it was EPA's position that it lacked the authority under the CAA to regulate $\mathrm{CO}_{2}$. See supra note 69 and accompanying text.

232. State AGs Letter, supra note 223, at 3.

233. Kan. Op. Att'y Gen. No. 2007-31 (Sept. 24, 2007) [hereinafter AG Opinion], available at http://www.kdheks.gov/press_room.htm (click on Attorney General's Opinion). 
whether, in the absence of federal or state regulations setting limitations for a specific pollutant, K.S.A. 65-3012 authorizes the [S]ecretary [of $\mathrm{KDHE}$ ] to deny or modify an air quality permit, or place a stay on issuance of an air quality permit until state or federal regulations are enacted that address the pollutant. ${ }^{234}$

The Opinion notes that when an application for an air quality control permit is filed with KDHE, "the [S] ecretary may deny the application pursuant to K.S.A. 65-3008b for specified reasons." ${ }^{235}$ Its analysis focuses, however, on section 65-3012. Under that provision of the Kansas Air Quality Act,

[n]otwithstanding any other provision of this Act, the [S]ecretary may take such actions as may be necessary to protect the health of persons or the environment: (1) Upon receipt of information that the emission of air pollution presents a substantial endangerment to the health of persons or to the environment....

Once section 65-3012 has been triggered, the Secretary may take actions "includ[ing] but not limited to" those specified in the statute. ${ }^{237}$ The Opinion noted that these include:

(1) issuing an order to an owner or operator to prevent an act or eliminate a practice with respect to a facility or site, including temporary cessation of operation, (2) commencing an action, or requesting the attorney general or county attorney to commence an action, to enjoin acts or practices, and (3) applying for a court order directing compliance with the order of the [S] ecretary. ${ }^{238}$

The Opinion stated that the Attorney General's office had found no appellate court decisions interpreting these provisions. ${ }^{239}$ Accordingly, the Attorney General ascertained the legislature's intent by analyzing the text of section 65-3012, which he found to be "plain and unambiguous." 240

234. Id.

235. Id. KAN. StAT. ANN. $§ 65-3008 b$ (c) (2002) authorizes the Secretary to deny a permit "if the owner or operator of such a source fails to demonstrate to the satisfaction of the secretary that any other stationary source owned or operated by such person" is in compliance with "all applicable emission limitations and standards under" the Kansas Air Quality Act and the federal CAA.

236. KAN. STAT. ANN. § 65-3012(a) (2002).

237. Id. $\S 65-3012(\mathrm{~b})$.

238. AG Opinion, supra note 233 (citing KAN. STAT. ANN. § 65-3012(b)).

239. Id.

240. Id. 
The Attorney General interpreted the plain language of the statute to "contemplate[] preventive as well as remedial actions on the part of the secretary in order to protect persons and the environment in situations where the secretary receives information that emission of air pollution presents substantial endangerment to either." ${ }^{241}$ The Opinion pointed out that both the terms "air pollution" 242 and "air contaminant" 243 are broadly defined. $^{244}$ The Attorney General reasoned, based on these provisions, that the Secretary need not wait to take action under section 65-3012 to prevent air pollution "until there are federal or state regulations establishing limitations on a particular pollutant," as long as he makes the findings required by section $65-3012$ (a). ${ }^{245}$

The Opinion added that the legislative history of section $65-3012$ supports this expansive reading of the Secretary's authority. Before 1993, the Air Quality Act limited the Secretary to taking "remedial action" when the agency found that "any person is causing or contributing to air pollution and that such pollution creates an emergency which requires immediate action to protect human health or safety." 246 Under those circumstances, KDHE, after following appropriate procedures and with the concurrence of the Governor, could issue an order requiring the immediate reduction or discontinuation of air contaminants. The Kansas legislature amended the statute in 1993, patterning the amended statute on the state's hazardous waste statute. ${ }^{247}$ That law authorizes the Secretary, "upon receipt of information that the ... disposal of any waste may present a substantial hazard to the health of persons or to the environment ... may take such action as ... necessary to protect the health of such persons or the environment."248 According to the Attorney General, "[t]hose actions include preventing the act or eliminating the practice constituting the hazard." 249 The

241. Id.

242. The statute defines "air pollution" to mean (unless the context clearly requires otherwise) "the presence in the outdoor atmosphere of one or more air contaminants in such quantities and duration as is, or tends significantly to be, injurious to human health or welfare, animal or plant life, or property, or would unreasonably interfere with the enjoyment of life or property, or would contribute to the formation of regional haze." KAN. STAT. ANN. § 65-3002(c) (2002 \& Supp. 2007).

243. The statute defines "air contaminant" to mean "dust, fumes, smoke, other particulate matter, vapor, gas, odorous substances, or any combination thereof, but not including water vapor or steam condensate." Id. § 65-3002(a).

244. AG Opinion, supra note 233.

245. Id.

246. Id. (quoting KAN. STAT. ANN. § 65-3012(a) (1993)).

247. That statute, section 65-3419(e), has not been amended since 1993.

248. KAN. STAT. ANN. § 65-3419(e) (2002).

249. AG Opinion, supra note 233, at 2. 
Opinion admitted that it is not clear from the then-KDHE Secretary's written testimony to the Senate Committee on Energy and Natural Resources whether the change was meant to enhance the Secretary's authority, rather than merely to "update ... outdated language." Opinion reasoned, however, that when the legislature amends a statute, "it is presumed that the legislature intended to make a change. Therefore, we beli[e]ve that the legislature bestowed upon the secretary the power to take preventive measures to address air pollution before it occurred." 251

Based on the statutory text and the legislative history, the Attorney General expressed his bottom line as follows:

[I]f the secretary makes a factual determination that a particular emission constitutes air pollution and that such emission presents a substantial endangerment to the health of persons or to the environment, then even in the absence of federal or state regulations setting limitations for a particular pollutant, K.S.A. 65-3012(a)(1) authorizes the secretary to take actions as necessary to protect the health of persons or the environment. Such actions may include denying an air quality permit application on the basis of anticipated emissions of a particular pollutant or modifying a proposed permit to address such pollutant.

\section{The KDHE Staff Recommendation}

Several weeks after issuance of the Attorney General's Opinion, KDHE's staff recommended issuance of an air quality construction permit to Sunflower to allow it to build the two new 700-megawatt coalfired steam generating units at its Holcomb generating station. ${ }^{253}$ Its recommendation identified plant operating conditions, including enforceable limitations on emissions of various air pollutants, not including $\mathrm{CO}_{2}$, as well as emissions testing and monitoring and recordkeeping and reporting requirements. ${ }^{254}$ The staff made only two brief references to GHGs. It noted that one of the public comments filed with KDHE had argued that the agency should address $\mathrm{CO}_{2}$ issues. The

250. Id. at 3 .

251. Id.

252. Id. The Opinion also expressed "serious reservations," however, that section 65-3012 would allow the Secretary to issue an indefinite stay of a permit "until such time-if ever - that state regulations are adopted addressing a particular pollutant." Id. These reservations were based in part on due process concerns. Id.

253. KDHE STAFF RESPONSIVENESS SUMMARY, supra note 3.

254. Id. at 1 . 
staff responded that " $[\mathrm{t}]$ here are no provisions to regulate carbon dioxide in PSD permits. These comments were referred to Secretary Bremby for further policy considerations. ${ }^{255}$ Similarly, the Sierra Club had argued that KDHE was required to deny the permit because the proposed plant would emit GHGs and mercury at rates that pose a substantial endangerment to the public health and the environment. The staff made the same response, referring the issue to Secretary Bremby. ${ }^{256}$

The staff recommendation does not conflict with the Attorney General's Opinion. It states that KDHE lacks the specific authority to address $\mathrm{CO}_{2}$ issues when it issues PSD permits. The Attorney General's Opinion, however, does not address the scope of KDHE's authority to deny a permit under the PSD provisions of the CAA and associated Kansas statutes and regulations. Instead, the Opinion is based upon an interpretation of section 65-3012 of the Kansas Air Quality Act. The staff recommendation explicitly avoided addressing the scope of the Secretary's authority to address climate change under that provision, deferring the issue to the Secretary for resolution on policy grounds.

\section{KDHE's Decision and Its Aftermath}

KDHE Secretary Ronald Bremby announced his decision on October 18, 2007, the day after the release of the staff recommendation (and nearly a month after the issuance of the Attorney General's Opinion). ${ }^{257}$ In his brief letter, Bremby began by referring to his duty as KDHE Secretary under the Kansas Air Quality Act "to protect the public health and environment from actual, threatened or potential harm from air pollution." ${ }^{258}$ Bremby interpreted the Act and KDHE's implementing regulations as vesting in the Secretary broad authority to protect health and the environment, including the denial of an air quality permit under section 65-3008a. ${ }^{259}$ Bremby also cited section 65-3012. ${ }^{260}$ He read that statute to authorize the Secretary to take actions necessary to protect health and the environment from the emission of air pollutants that present a substantial endangerment, which "may be a threatened or potential harm as well as an actual harm."

255. Id. at 9 .

256. Id. at $14-15$.

257. Bremby Letter, supra note 4.

258. Id.

259. Id.

260. Id.

261. Id. 
Court's decision in April 2007 in Massachusetts v. EPA, in which the Court held that $\mathrm{CO}_{2}$ qualifies as an air pollutant under the federal $\mathrm{CAA}^{262} \mathrm{He}$ reasoned that " $\left.\mathrm{t}\right]$ he Kansas air quality act similarly has a broad definition of what constitutes air pollution." 263 The Secretary also referred to the Supreme Court's recognition of the "deleterious impact of greenhouse gases on the environment in which we live."264 Similarly, Bremby concluded that the information gathered during the Sunflower permit proceeding "provides support for the position that emission of air pollution from the proposed coal fired plant, specifically carbon dioxide emissions, presents a substantial endangerment to the health of persons or to the environment." ${ }^{265}$ Based on that information, Secretary Bremby denied the permit.

KDHE issued a press release the same day, quoting Bremby and reiterating the basis for his decision. ${ }^{266}$ The release quoted Bremby as stating that he decided to deny the Sunflower permit "[a]fter careful consideration of my responsibility to protect the public health and environment from actual, threatened or potential harm from air pollution" under sections 65-3008, 65-3008a, and 65-3012. ${ }^{267}$ Bremby added that "it would be irresponsible to ignore emerging information about the contribution of carbon dioxide and other greenhouse gases to climate change and the potential harm to our environment and health if we do nothing." 268 The release characterized Bremby's decision as "a first step in emerging policy to address existing and future carbon dioxide emissions in Kansas." 269 It noted that the two new Sunflower

262. Id. (citing Massachusetts v. EPA, 127 S. Ct. 1438, 1459-60 (2007)).

263. Id. See also Written Testimony of Roderick L. Bremby, Secretary, Kan. Dep't of Health \& Env't, House Select Committee on Energy Independence and Global Warming, Hearings on "Massachusetts v. U.S. EPA Part II: Implications of the Supreme Court's Decision," Mar. 13, 2008, at 2 ("The Supreme Court's finding that greenhouse gases are an air pollutant within the meaning of the federal Clean Air Act supports and confirms my own determination that $\mathrm{CO}_{2}$ constitutes air pollution within the meaning of the Air Quality Act.") [hereinafter Bremby Testimony].

264. Bremby Letter, supra note 4.

265. Id.

266. Press Release, Kan. Dep't of Health \& Env't, KDHE Denies Sunflower Electric Air Quality Permit (Oct. 18, 2007), available at http://www.kdheks.gov/news/web archives/2007/ 10182007a.htm [hereinafter Sunflower Press Release].

267. Id.

268. Id. According to the release, the Centers for Disease Control and Prevention have "recognized the need for public health agencies to take the lead on educating the public about the health impacts of climate change and [have] adopted priority health actions to prepare for, respond to and manage the associated health risks of climate change." Id.

269. Id. According to Bremby, "KDHE will work to engage various industries and stakeholders to establish goals for reducing carbon dioxide emissions and strategies to achieve them. This is consistent with initiatives underway in states leading the effort to address climate change." Id. As an example, the release cited the RGGI mandatory, regional cap-and-trade program for reducing $\mathrm{CO}_{2}$ 
units would have released a projected eleven million tons of $\mathrm{CO}_{2}$ each year, and quoted Bremby to the effect that "[d]enying the Sunflower air quality permit, combined with creating sound policy to reduce carbon dioxide emissions[,] can facilitate the development of clean and renewable energy to protect the health and environment of Kansans.

Reactions to the KDHE's decision were not long in coming. Governor Sebelius backed the decision. In an "open letter to the people of Kansas" she applauded the denial as a decision that would improve the health of Kansas residents, "improve prospects for 'sustainable economic growth,' and uphold a 'moral obligation to be good stewards of this beautiful land.",271 The governor expressed support for the pursuit of "'other, more promising energy and economic development alternatives." "272

Opposition to the decision from other quarters, however, was immediate and pointed. Criticism of the decision reflected two main arguments, one based on the alleged absence of legal authority and the other on the alleged adverse public policy implications of the permit denial. The first contention rested on the premise that KDHE acted outside the scope of its statutory and regulatory authority in denying an air quality permit for the Holcomb units. A spokesperson for Sunflower stated that the Supreme Court's decision in Massachusetts v. EPA merely permits regulation of $\mathrm{CO}_{2}$, but does not create such regulation, and that " $[t]$ here are no carbon dioxide regulations in the federal rules or in Kansas." 273 The President of the Kansas Senate and the Speaker of the Kansas House of Representatives argued in a newspaper editorial that neither EPA nor Kansas statutes "consider $\mathrm{CO}_{2}$ a pollutant. Kansas law does not give the Department of Health and Environment, its secretary or the governor the authority to limit an unregulated emission. In fact, the department's most recent Air Quality Report (2004-2005) makes no mention of $\mathrm{CO}_{2} \ldots ., 274$ Senator Brownback, whose reaction was quoted in part at the beginning of this article, added that "[o]ne thing remains

emissions from power plants by $10 \%$ by 2020 . See supra notes $98-99$ and accompanying text.

270. Sunflower Press Release, supra note 266.

271. Rejection, supra note 65 , at 2363.

272. Id.

273. Wald, supra note 11. The plant's supporters claimed that it was the first time any state had denied a permit for a large coal-fired power plant solely because of its potential impact on global warming, implying that the decision was unprecedented, and therefore without legal foundation. Id.

274. Morris \& Neufeld, supra note 216. President Morris argued elsewhere that "[w]e don't really have problems, in my opinion, with clean air here. Yet we're at the forefront of trying to regulate something that's arguably, in some people's view, a pollutant. There are other folks who don't think it is." Legislators Limited in Fighting Coal Ruling, WiCHITA EAGLE, Nov. 13, 2007, at 3B. 
clear: [c]ritical issues important to Kansas such as climate change should be decided by the citizens in Kansas, in concert with the governor, and not by administrative fiat." 275

The thrust of the policy-based criticism was that the permit denials would have a devastating economic impact on the state to avoid a nonexistent or insignificant environmental problem. ${ }^{276}$ The State Senate President and House Speaker asserted that the denial would have "a considerable negative impact on our state budget, other Kansas industries, economic development and the security of our state's energy future." ${ }^{277}$ They added that efforts to mandate carbon reductions "below market levels will increase energy costs for Kansas consumers and businesses [and] companies considering locating or expanding in Kansas may reconsider if a reliable source of reasonably priced energy is not available." ${ }^{278}$ Senator Brownback charged that the environmental impact of the "integrated bioenergy center" planned for Holcomb would have been positive, not negative. ${ }^{279} \mathrm{He}$ claimed that the center would incorporate an ethanol plant and sequester up to $40 \%$ of the units' $\mathrm{CO}_{2}$ output. ${ }^{280}$ The sequestered gas, in turn, would be used to grow algae, which could be used to produce "earth-friendly biodiesel fuel.,"281 According to Senator Brownback, the Holcomb project would displace less efficient coal-fired units elsewhere, contribute less to climate change

275. Brownback, supra note 2.

276. Representative Larry Powell of Garden City, Kansas even claimed that the $\mathrm{CO}_{2}$ emitted by the Sunflower plants would be beneficial to the state because " plants perform better under stress (drought, etc.) with increased levels of $\mathrm{CO}_{2}$. ." Randy Scholfield, $\mathrm{CO}_{2}$-Warming a Farm Program?, Wichita EAGLE, Dec. 1, 2007, at 7A. Powell added that over the next fifty years, "'atmospheric $\mathrm{CO}_{2}$ enrichment will boost world agricultural output by about 50 percent." Scott Rothschild, Plants' $\mathrm{CO}_{2}$ Would Help Crops, Lawmaker Says, LAWrenCe J.-World, Nov. 29, 2007, at 1 A. "Powell cited a report by Craig and Keith Idso of the Arizona-based Center for the Study of Carbon Dioxide and Global Climate Change." Id. The Center's website states that it "accepts corporate, foundation and individual donations," without disclosing its donors. $\mathrm{CO}_{2}$ Science, https://www.Co2science.org/content/view/22/42/ (last visited Apr. 7, 2008). ExxonMobil apparently made a $\$ 10,000$ contribution to the Center in 2001 and "StopExxon.org reports that CSCDGC has received \$90,000 from ExxonMobil between 1998 and 2005." Center for the Study of Carbon Dioxide and Global Change-Source Watch, http://www.sourcewatch.org/index.php?title= Center_for_the_Study_of_Carbon_Dioxide_and_Global_Change (last visited Apr. 7, 2008). Governor Sebelius countered Representative Powell's argument by asserting that "[1]ess water and hotter temperatures will result in fewer crops and less production." Rejection, supra note 65, at 2364.

277. Morris \& Neufeld, supra note 216; see also Legislators Limited in Fighting Coal Ruling, WiChitA EAGLE, Nov. 13, 2007, at 3B (describing argument of opponents of KDHE's decision that if Sunflower is forced to use natural gas instead of coal, the result will be higher rates charged to its customers).

278. Morris \& Neufeld, supra note 216.

279. Brownback, supra note 2.

280. Id.

281. Id. 
than those less efficient plants would, ${ }^{282}$ and increase the nation's energy security. ${ }^{283}$ Senator Brownback feared that the decision would create a dangerous precedent: "One is left to wonder what Kansas industry is next in line on the slippery slope to be denied an air-quality permit. Is it the burgeoning ethanol industry, the booming aircraft industry or the world class cattle industry?"284 He argued that "reasonable" electricity prices and "a stable regulatory environment" has traditionally acted as a magnet, drawing new businesses to the state and persuading existing businesses to expand. ${ }^{285}$ Secretary Bremby's decision "throws that to the wind with a regulatory decision made outside of statutory authority.",286

Sunflower filed a request for reconsideration with KDHE shortly after Secretary Bremby announced his decision. ${ }^{287}$ The utility also filed two lawsuits seeking to overturn the decision. ${ }^{288}$ It filed one lawsuit in the Kansas Court of Appeals. ${ }^{289}$ The company's main argument echoed the criticisms of the decision based on the agency's alleged lack of statutory authority. ${ }^{290}$ According to the suit, KDHE had no authority under state law to deny the permit and it applied a statute to prospective air emissions that the utility argues applies only to current emissions. ${ }^{291}$ It filed a similar lawsuit in Finney County District Court, ${ }^{292}$ and similar suits were filed by Tri-State Generation and Transmission Association, the Finney County Commission, and the Garden City Chamber of

282. Id. KDHE apparently was not convinced that Sunflower demonstrated that the bioenergy center would actually cut emissions to 3.6 million tons per year. See Utility Sues Over Coal-Plant Denial, supra note 217 ("Many environmentalists say the technology is too experimental for the state to count upon it to reduce $\mathrm{CO}_{2}$."). Similarly, environmental groups claimed that the technology envisioned for use at the bioenergy center was too experimental to be reliable. High Court Takes on Coal Appeals, supra note 222.

283. Brownback, supra note 2. Similar criticisms have been leveled against federal environmental statutory provisions that regulate new pollution sources relatively rigorously. These sometimes are said to create "an incentive for sources to keep older, dirtier plants in operation as long as possible in order to avoid triggering the more rigorous controls applicable to new plants. The result is arguably bad not only for the environment, but also for the economy, as the construction of newer, more efficient and productive plants is delayed." ROBERT L. GLICKSMAN ET AL., Environmental Protection: LAW And Policy 451 (5th ed. 2007) (citing Bruce A. Ackerman \& Richard B. Stewart, Reforming Environmental Law, 37 StAN. L. REV. 1333, 1335-36 (1985)).

284. Brownback, supra note 2.

285. Id.

286. Id.

287. Finney County May Sue State over Permit Denial, WichitA EAGLE, Nov. 15, 2007, at 3 B.

288. Utility Sues over Coal-Plant Denial, WiCHITA EAGLE, Nov. 30, 2007 at 3B.

289. Id.

290. Id.

291. Id.

292. Id. 
Commerce. $^{293}$ In late November 2007, the Kansas Supreme Court transferred both cases to it on its own motion, without a request from the parties. $^{294}$ The following April, however, the court issued a one-page order which, without explanation, stayed all of the appeals pending the completion of the administrative reconsideration proceedings before KDHE and the proceedings in Finney County District Court, unless the Kansas Supreme Court orders otherwise. ${ }^{295}$

Concurrently with the filing of administrative and judicial appeals of KDHE's decision, the supporters of the plant sought to reverse the decision by statute. The 2008 session of the Kansas legislature was consumed almost entirely by a pitched battle over the fate of the Holcomb units. The legislature passed three bills that would have required KDHE to approve Sunflower's application ${ }^{296}$ and stripped KDHE of its authority to regulate GHG emissions in the absence of federal regulation. ${ }^{297}$ More specifically, the second bill would have prohibited KDHE from issuing air quality regulations that are more stringent than federal requirements absent the approval of the state legislature, ${ }^{298}$ prohibited KDHE from denying air quality permits if the provisions of the statute that specifically bear on permitting are met, ${ }^{299}$ and allowed KDHE to invoke the substantial endangerment statute only in the event that existing sources of air pollution pose an imminent and

293. High Court Takes on Coal Appeals, supra note 222

294. Id.; see also State Supreme Court to Hear Appeal of Denial of Air Permit for Power Plant, 38 ENV'T REP. (BNA) 2628 (Dec. 7, 2007) (citing Tri-State Generation and Transmission Ass'n v. Kan. Dep't of Health \& Env't, No. 07-99566 (Kan. Nov. 27, 2007)).

295. Tri-State Generation and Transmission Ass'n v. Kan. Dep't of Health \& Env't, Nos. 99,566, 99,567, 99,568 (Kan. Apr. 24, 2008).

296. See The House substitute for S.B. 148, § 30(d) (2008), available at http://www. kslegislature.org/bills/2008/148.pdf [hereinafter S.B. 148] (providing that any action by the KDHE Secretary on an application filed after January 1, 2006, and before the effective date of the 2008 legislation which seeks the issuance, modification, revision or renewal of a permit, "and which is still the subject of any administrative or judicial review proceedings, shall be reconsidered by the secretary upon the applicant's or permittee's timely written request"). The Secretary then would have been required within fifteen days of such a filing to reconsider his decision and "determine in accordance with the provisions of this act, as amended, whether the issuance, modification, amendment, revision or renewal of any approval or permit requested by the permittee or applicant should be issued, modified, amended, revised or renewed." See also id. § 31(b) (requiring the Secretary to "affirm the issuance of any permit the terms and conditions of which comply with all requirements established by rules and regulations promulgated pursuant to the Kansas air quality act").

297. See Susanne Pagano, State Lawmakers Approve Legislation to Allow Expansion of CoalFired Plant, 39 ENV'T REP. (BNA) 368, Feb. 22, 2008 (describing the enactment of the first bill); Scott Rothschild, Second Coal Plant Bill OK'd, LAWrence J.-World, Apr. 5, 2008, at 1B; Scott Rothschild, Legislature Signs Off Session with Coal Bill, LAWrENCE J.-WORLD, May 8, 2008, at 1A.

298. S.B. 148, supra note 296, § 30(b)(1) (2008).

299. Id. §30(b)(3). 
substantial threat to health or the environment. ${ }^{300}$ Governor Sebelius vetoed the first two bills bills. ${ }^{301}$ The state Senate voted to override the two vetoes, ${ }^{302}$ but the Kansas House fell just short of the votes needed to override. ${ }^{303}$ The plant's supporters nevertheless persisted. The House Majority Leader and House Speaker introduced a resolution that would allow legislative leaders to hire private counsel to sue Governor Sebelius and other executive branch officials for exceeding their constitutional authority. ${ }^{304}$ In addition, on what was supposed to be the last day of the wrap-up session of the 2008 legislative term, the Holcomb plant's supporters inserted into several economic development proposals provisions similar to those in the two bills successfully vetoed by the Governor. The Governor promptly vetoed the third bill, and the legislature adjourned without mustering an effort to override it. ${ }^{305}$ The

\section{Section 30 (c) of S.B. 148 provided that:}

In as much as K.S.A. 65-3012, and amendments thereto, does not now apply, nor has it ever been applicable, to the air quality permitting process, the secretary may not use the emergency powers granted by K.S.A. 65-3012, and amendments thereto, in the air quality permitting process, nor any powers or discretion under any other statute not strictly applicable to the air quality permitting process.

$I d$. $\S 30(\mathrm{c})$. Section 33 would have amended $\S 65-3012$ (a) to provide that:

Notwithstanding any other provision of this act, the secretary may take such action against any existing source as may be necessary to protect the health of persons or the environment: (1) Upon receipt of information that the emission of air pollution presents an imminent and substantial endangerment to the health of persons or to the environment....

Id. $\S 33$ (emphasis added). See also Christopher Brown, Governor Vetoes Second Bill to Allow Coal-Fired Power Units in Western Kansas, 39 ENV'T REP. (BNA) 825, Apr. 25, 2008.

301. See Felicity Barringer, Kansas Governor Vetoes Bill to Revive 2 Coal-Fired Plants, N.Y. TimES, Mar. 22, 2008, at A10 (describing the Governor's veto of the first bill); Brown, supra note 300 , at 824 (describing the Governor's veto of the second bill); Susanne Pagano, Governor Vetoes Legislation to Allow Expansion of Coal-Fired Power Plant, 39 ENV'T REP. (BNA) 623, Mar. 28, 2008 (describing the Governor's veto of the first bill).

302. See Scott Rothschild, Power Plant Struggle Resumes, LAwrenCE J.-World, May 1, 2008, at $1 \mathrm{~A}$ (second bill).

303. See Scott Rothschild, Sebelius' Coal Veto Stands, LAWrenCE J.-World, May 2, 2008, at 1A (describing "a dramatic showdown" in which the Holcomb plant's supporters fell four votes short of the two-thirds majority needed to override the Governor's veto). After the vote, House Speaker Melvin Neufeld predicted that the vote would stunt economic development and increase energy costs in the western part of the state. Id. The Sierra Club responded that the vote "solidifies Kansas as a true leader in the fight against global warming." Id.

304. House Concurrent Resolution No. 5042 provided:

That the legislative coordinating council is authorized to hire private legal counsel ... to bring suit against the governor and other executive branch officers as appropriate on the grounds of violation by the executive branch of the constitutional doctrine of separation of powers and such other legal grounds as may be appropriate based on the governor's and the executive branch's actions relating to the authorization of a coal-fired power plant to be located in the Holcomb, Kansas, area of the state.

H.C.R. 5042 (2008), available at http://www.kslegislature.org/bills/2008/2008_5042.pdf.

305. Scott Rothschild, Coal Power Plant Issue Keeps Lawmakers from Wrapping up, 
legislature's failure to overturn the third veto left the fate of Secretary Bremby's decision in the hands of the Kansas courts.

\section{KDHE's STATUTORY AUTHORITY AND CLIMATE CHANGE}

Secretary Bremby's denial of the Sunflower air quality permits has been challenged on several grounds. ${ }^{306}$ Some challenges are based on the premise that KDHE has misinterpreted the scope of its statutory authority and acted outside that authority in rejecting Sunflower's permit application. In particular, the utility and its supporters attacking Bremby's decision have made two primary assertions that the decision exceeds the bounds of KDHE's statutory authority. First, they claim that KDHE erroneously denied a permit for a proposed facility by invoking a statute that only authorizes the agency to take actions to abate ongoing activities that pose substantial endangerments to health and the environment. Second, they claim that the substantial endangerment provision, which provides the principal underpinning of Bremby's decision, does not apply to substances not already being regulated as air pollutants under federal or state law. Additional challenges attack the Secretary's factual and policy determinations, even assuming that he did not exceed the bounds of the agency's delegated authority.

This part focuses primarily on the claims that KDHE lacked the statutory authority to deny the Sunflower air quality permits. Section A concludes that, based on the applicable standards of judicial review of an administrative agency's statutory authority, those claims should fail. Section B establishes the framework for judicial review of the validity of the factual and policy determinations underlying the permit denial. It concludes that review of these claims ought to be deferential and that the kinds of risks to health and the environment upon which Secretary Bremby based his decision are well within the scope of the substantial endangerment provision.

LAWrEnCE J.-World, May 4, 2008, at 1A; John Hanna, Sebelius Vetoes Third Bill Allowing CoalFired Plants, LAWRENCE J.-WORLD, May 17, 2008, at 4B; Scott Rothschild, Coal Battle Moves to Court, LAWRENCE J.-WorLD, May 22, 2008, at 1A.

306. This article does not address the procedural challenges against KDHE's decision raised by Sunflower, including lack of notice, lack of opportunity to be heard, and violation of procedural due process rights. See Sunflower Elec. Power Corp. v. Kan. Dep't of Health \& Env't, Petition for Judicial Review of KDHE Denial of Permit Application Under K.S.A. § 65-3012(a), at 9, 10-11, Case No. 07CV245 (25th Jud. Dist. at Finney County Nov. 16, 2007). 


\section{A. Statutory Interpretation Challenges}

In litigation and in public comments criticizing KDHE's denial of the Sunflower permit application, those challenging the decision have provided at least two reasons why the agency lacked the authority to deny the permit. ${ }^{307}$ First, those who disagree with the decision charge that KDHE has the authority under the substantial endangerment statute to react to existing emissions from a plant that is already in operation, but not to prevent prospective emissions from a proposed plant. ${ }^{308}$ Second, they assert that KDHE may not reject an air quality permit on the basis of emissions of pollutants not currently being regulated under the federal CAA or the Kansas Air Quality Act. Neither contention warrants overturning the Secretary's decision.

\section{Standard of Review}

The framework for resolution of any litigation challenging the validity of KDHE's decision on the Holcomb units is established by the Kansas Act for Judicial Review and Civil Enforcement of Agency Action, ${ }^{309}$ and particularly by that statute's scope of review provisions. The Act imposes the burden of proving the invalidity of agency action, such as Secretary Bremby's decision, on the challenging party. ${ }^{310}$ The Judicial Review Act authorizes Kansas's courts to "grant relief" to a party challenging an agency's decision if "the agency has acted beyond the jurisdiction conferred by any provision of law" or "the agency has erroneously interpreted or applied the law."311 The charges that KDHE may not act preventively under the substantial endangerment provision

307. See supra notes $273-75$ and accompanying text.

308. In the complaint it filed in district court in Finney County, Sunflower asserted that the denial is invalid because Secretary Bremby "has erroneously interpreted or applied Section 3012, in that [the statute] only addresses current air pollution that results from existing stationary and mobile sources of air contaminant emissions and thus provides no authority or jurisdiction to the Secretary to deny a permit to construct a new source of such emissions." Petition for Judicial Review of KDHE Denial of Permit Application Under K.S.A. § 65-3012(a), supra note 306, at 10; see also id. at 8 (noting that before September 2007, the substantial endangerment provision of the Kansas Air Quality Act "had only been applied to existing pollution that presents an air pollution emergency and therefore had never been considered by KDHE in connection with an application for a PSD construction permit for a new source of future emissions"); Sunflower Elec. Power Corp. v. Kan. Dep't of Health \& Env't, Petition for Review of KDHE Denial of Permit Application Under K.S.A. $\S 65-3008 \mathrm{a}(\mathrm{b})$, at 9 (Kan. Ct. App. Nov. 16, 2007).

309. KAN. Stat. ANN. §§77-601 to 77-631 (1997).

310. Id. § 77-621(a)(1); see also Foos v. Terminix, 89 P.3d 546, 551 (Kan. 2004) (“[T]he party asserting [an agency's] action is invalid bears the burden of proving the invalidity.").

311. KAN. STAT. ANN. § 77-621(c)(2), (4). 
and may not deny an air quality permit on the basis of emissions of "unregulated pollutants" amount to the contention that KDHE acted beyond its jurisdiction under the Air Quality Act and that it has erroneously interpreted the Act to enable it to deny permits under circumstances that the legislature did not envision. Thus, resolution of these charges requires judicial review of KDHE's interpretation of the Act.

The Kansas appellate courts frequently state that because statutory interpretation is a question of law, judicial review of an agency's interpretation is "unlimited." 312 The Kansas courts, however, adhere to "the doctrine of operative construction," under which an administrative agency's interpretation of a statute it is responsible for administering is entitled to judicial deference. ${ }^{313}$ On the one hand, the Kansas Supreme Court has stated that "[i]f there is a rational basis for the agency's interpretation, it should be upheld on judicial review." "314 On the other hand, the court also routinely announces that " $[\mathrm{t}]$ he determination of an administrative body as to questions of law is not conclusive and, while persuasive, is not binding on the courts."

The Kansas Supreme Court also has taken the position that judicial deference to agency statutory interpretations is particularly appropriate when the agency has "special competence and experience" in the subject matter involved in the interpretation. ${ }^{316}$ It is hard to imagine the Kansas Supreme Court concluding that KDHE does not possess such expertise in

312. See, e.g., In re City of Wichita, 59 P.3d 336, 343-44 (Kan. 2002) (describing the court's review of a tax exemption statute).

313. Trees Oil Co. v. State Corp. Comm'n, 105 P.3d 1269, 1281 (Kan. 2005).

314. Foos, 89 P.3d at 551 (quoting Kan. Dep't of Soc. \& Rehab. Servs. v. Public Employee Relations Bd., 815 P.2d 66, 70 (Kan. 1991)).

315. Id.; see also Ninemire v. Kan. Dep’t of Soc. \& Rehab. Servs., 162 P.3d 22, 25 (Kan. 2007) ("Under the doctrine of operative construction, courts have given deference to an administrative agency's interpretation of a statute it has been charged with enforcing. 'However, "[t]he final construction of a statute [always] rests within the courts."” (quoting Fieser v. Kan. Bd. of Healing Arts, 130 P.3d 555, 557 (Kan. 2006))); Peterson v. Kan. Dep't of Health \& Env't, 59 P.3d 610 (Kan. Ct. App. 2002) (noting that the agency's interpretation is persuasive but not binding). The leading U.S. Supreme Court case governing judicial review of agency statutory determinations has long been Chevron U.S.A., Inc. v. Natural Res. Def. Council, Inc., 467 U.S. 837 (1984), which just happens to be a CAA case. For recent commentary on Chevron, see Jacob E. Gersen \& Adrian Vermeule, Chevron as a Voting Rule, 116 YALE L.J. 676 (2007); Daniel J. Gifford, The Emerging Outlines of a Revised Chevron Doctrine: Congressional Intent, Judicial Judgment, and Administrative Autonomy, 59 Admin. L. REv. 783 (2007); Linda Jellum, Chevron's Demise: A Survey of Chevron from Infancy to Senescence, 59 ADMIN. L. REV. 725 (2007).

316. Coma Corp. v. Kan. Dep't of Labor, 154 P.3d 1080, 1083 (Kan. 2007); Hawley v. Kan. Dep’t of Agric., 132 P.3d 870, 878 (Kan. 2006); Fisher v. Kan. Crime Victims Comp. Bd., 124 P.3d 74, 78 (Kan. 2005) (quoting In re Appeal of United Teleservices, Inc., 983 P.2d 250, 252 (Kan. 1999)). 
matters involving the public health and environmental effects of air pollution. $^{317}$

The Kansas Supreme Court has recognized limits to the doctrine of operative construction. The doctrine does not apply in the absence of "uncertainty or ambiguity." 318 In addition, the court has professed reluctance to apply the doctrine when the issue before it raises "questions of law on undisputed facts." 319 Even then, however, the agency's determination on a question of law is persuasive, even if it is not binding on a court. ${ }^{320}$

One should not make too much of these largely boilerplate recitations of the standard of review applicable to judicial review of agency statutory interpretations. Two leading administrative law scholars once quipped that "the rules governing judicial review have no more substance at the core than a seedless grape." 321 Still, it is clear that the burden of proof is on those challenging the Holcomb units' denial. Further, at least some, and perhaps considerable, deference is likely to be afforded KDHE's interpretation of the scope of its authority under the air quality act to deny a permit to a power plant based on the potential adverse effects of its emissions of $\mathrm{CO}_{2}{ }^{322}$

\section{Reactive vs. Preventive Regulation}

One legal issue raised by KDHE's denial of the Sunflower application is whether KDHE has the authority to deny a permit on the basis of prospective as opposed to current emissions. ${ }^{323}$ Secretary Bremby's letter explaining the permit denial cited sections $65-3008 \mathrm{a}(\mathrm{b})$

317. Cf. Trees Oil Co., 105 P.3d at 1280 (recognizing the District Court's ruling that the Kansas Corporation Commission "is an agency of special competence and experience in oil and gas matters with prevention of waste being of primary importance").

318. Winnebago Tribe of Neb. v. Kline, 150 P.3d 892, 903 (Kan. 2007).

319. Graham v. Dokter Trucking Group, 161 P.3d 695, 701 (Kan. 2007) (citing Fieser, 130 P.3d at 557).

320. Fieser, 130 P.3d at 557.

321. Ernest Gellhorn \& Glen O. Robinson, Perspectives on Administrative Law, 75 ColuM. L. REV. 771, 780 (1975).

322. KDHE's reliance on an opinion of the state Attorney General will not enhance the degree of deference to which KDHE's interpretation is entitled. The Kansas Supreme Court has "long held that ' $[t]$ he construction placed upon a statute by the opinion of an attorney general is neither conclusive nor binding on the court, and in circumstances where such an opinion is without authoritative legal support, it should not be approved or followed."' Perry v. Bd. of County Comm'rs, 132 P.3d 1279, 1288 (Kan. 2006) (citing Greenwood v. Estes, Sav. \& Loan Comm'r, 504 P.2d 206, 207 (Kan. 1972)).

323. See supra note 308 and accompanying text. 
and $65-3012$ as the statutory basis for his decision. ${ }^{324}$ The KDHE press release issued the same day also referred to section $65-3008 .^{325}$ It is obvious that sections $65-3008$ and $65-3008 \mathrm{~b}$ do not preclude the agency from denying an air quality permit on the basis of prospective as opposed to current emissions; a serious argument to the contrary is impossible to make. The statute prohibits any person from constructing or operating any air contaminant emission stationary source if the Secretary finds that it "may cause or contribute to air pollution, unless an appropriate approval or permit has been issued for the source by the secretary" under the Air Quality Act. ${ }^{326}$ The prohibition applies to stationary sources that "may cause or contribute to air pollution," 327 rather than to sources that have caused or are causing air pollution. Further, the statute bars the construction as well as the operation of an air contaminant emission stationary source without a permit. ${ }^{328}$ It is clear that a source owner must apply for and receive a permit before it constructs the source and that KDHE is responsible for determining whether to issue a permit at that time, which, by definition, is before any emissions are discharged into the air.

If there is any limit on the agency's authority to preclude potential future as opposed to ongoing emissions, it must come from section 653012, which was the focus of Secretary Bremby's letter, the accompanying KDHE press release, and the Attorney General's opinion that KDHE solicited before making a determination on the Sunflower permits. Section 65-3012(a) provides: "Notwithstanding any other provision of this act, the secretary may take such action as may be necessary to protect the health of persons or the environment: (1) Upon receipt of information that the emission of air pollution presents a substantial endangerment to the health of persons or to the environment .....329 The statute then describes the actions that KDHE

324. Bremby Letter, supra note 4 , at 1 .

325. Sunflower Press Release, supra note 266, at 1.

326. KAN. StAT. ANN. § 65-3008(a) (2002). An "air contaminant" means "dust, fumes, smoke, other particulate matter, vapor, gas, odorous substances, or any combination thereof." Id. $\S 65$ 3002(a). The Holcomb units would have emitted "air contaminants" in the form of the various criteria pollutants discussed in the staff recommendation, see supra notes 253-56 and accompanying text, as well as $\mathrm{CO}_{2}$, which is a gas. Each unit also would have qualified as a stationary source, which means "any building, structure, facility or installation which emits or may emit any air contaminant." Id. § 65-3002(1).

327. The statute defines "air pollution" as "the presence in the outdoor atmosphere of one or more air contaminants in such quantities and duration as is, or tends significantly to be, injurious to human health or welfare, animal or plant life, or property, or would unreasonably interfere with the enjoyment of life or property." Id. $\S 65-3002(\mathrm{c})$

328. Id. $\S 65-3008(\mathrm{a})$.

329. Id. $\S 65-3012(\mathrm{a})$ 
may take pursuant to that authorization, "includ[ing] but ... not limited to" the issuance of an order directing a source to "take such steps as necessary to prevent the act or eliminate the practice" giving rise to the endangerment. ${ }^{330}$ Such an order "may include ... temporary cessation of operation." 331 In addition, KDHE may commence an action to enjoin acts or practices referenced in section 65-3012(a), or request that the attorney general or appropriate county or district attorney do so. ${ }^{332}$ The court may issue a restraining order upon a showing by KDHE "that a person has engaged in those acts or practices.",333

The question is whether section 65-3012 applies only to ongoing activities, leaving the permit review provisions of section 65-3008 as the exclusive source of KDHE's authority to preclude the commencement of new activities (such as stationary source construction) that would, if allowed, give rise to undesirable air pollution problems. Section 65-3012 is broad enough to allow KDHE to block endangering activities before they have begun. Section 65-3012(b) grants to the Secretary the authority "to issu[e] an order directing the owner or operator, or both, to take such steps as necessary to prevent the act or eliminate the practice" giving rise to the endangerment. ${ }^{334}$ An order eliminating a practice is necessarily directed at activities that have already begun. One dictionary defines the word eliminate to mean to "cause to exist no longer." 335 Another defines it to mean "to put an end to." "336 Both definitions involve the cessation of an activity that has already begun. But section 653012(b) authorizes KDHE to prevent or eliminate an endangering activity. The same dictionaries make it clear that prevention entails blocking an activity that has not yet begun. One defines the word prevent to mean "act or do in advance" or "act before, in anticipation of, or in preparation for (a future event, a point in time)." ${ }^{\text {"37 }}$ The other defines the word to mean "to act ahead of" and "to keep from happening or existing." 338 The statute thus grants to KDHE the power to take action to protect health and the environment from the adverse effects of a

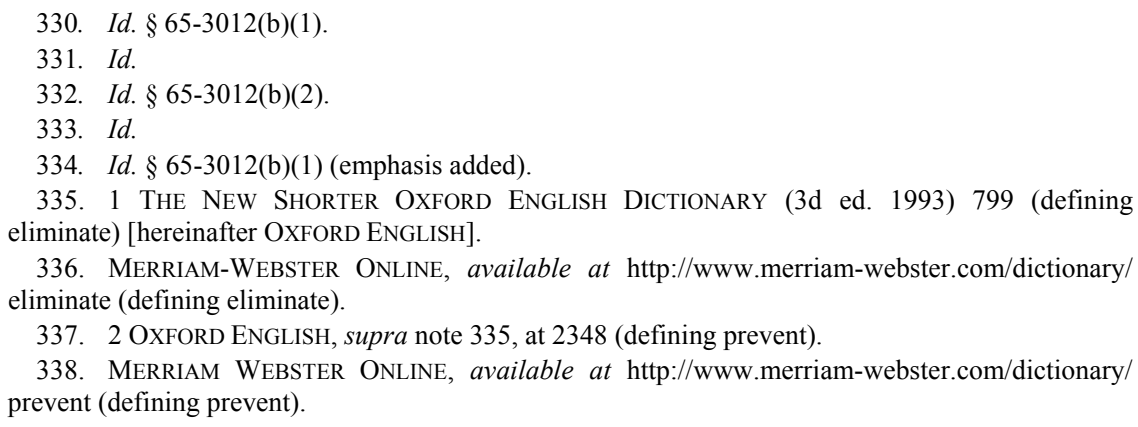


substantial endangerment either by eliminating it after the activities responsible for it have already begun or by preventing it before those activities have begun.

Some of the provisions of section 65-3012(b) are certainly backward looking, including the references to cessation of (presumably ongoing) operations and to a person that "has engaged" in the acts giving rise to the endangerment. ${ }^{339}$ The remedies listed in the statute, however, are simply illustrative of those authorized by the statute which, as indicated in the previous paragraph, undoubtedly encompasses preventive measures. The statute vests KDHE with the authority to take actions "includ[ing] but not limited to" the ones listed. ${ }^{340}$ Accordingly, the fact that some of the listed actions relate to the cessation of ongoing activities does not preclude the Secretary from taking actions directed at emissions that would pose a substantial endangerment were they to occur in the future.

The evolution of the statutory text also strongly supports the conclusion that the Secretary may take actions to block activities (such as denying an air quality permit) that present a substantial endangerment despite the fact that they have not yet begun. In particular, the 1993 amendments to section 65-3012(a) support the conclusion that the statute authorizes KDHE to address substantial endangerments to health or the environment either by preventing activities that have not yet begun or by ordering the cessation of ongoing endangering activities. As the Attorney General's opinion points out, before 1993, section 65-3012(a) limited the Secretary to taking "remedial action." might be construed as being limited to efforts to remedy an ongoing problem, ${ }^{342}$ although that reading is not inevitable. ${ }^{343}$ Even if the reference to "remedial action" is construed in such a narrow way, any limit that section 65-3012(a) once imposed on the Secretary's authority to act preventively disappeared in 1993, when the state legislature amended the provision to authorize KDHE to take "such actions as may

\footnotetext{
339. KAN. StAT. ANN. § 65-3012(b)(1), (2) (2002) (emphasis added).

340. Id. $\S 65-3012(\mathrm{~b})$.

341. See supra notes $246-52$ and accompanying text.

342. But cf. 42 U.S.C. $§$ 9601(24) (2000) (defining "remedial action" for purposes of the Comprehensive Environmental Response, Compensation, and Liability Act to mean actions "to prevent or minimize the release of hazardous substances so that they do not migrate to cause substantial danger to present or future public health or welfare or the environment").

343. See, e.g., MERRIAM-WEBSTER ONLINE, available at http://www.merriam-webster.com/ dictionary/remedy (emphasis added) (providing one definition of "remedy" as "the legal means to recover a right or to prevent or obtain redress for a wrong").
} 
be necessary" to protect health and the environment. ${ }^{344}$ The statute on its face therefore no longer applies exclusively to remediation of ongoing activities, but to any acts the Secretary deems necessary to protect health and the environment from a substantial endangerment, including the kinds of preventive actions explicitly covered by section 65-3012(b).

The text of 65-3012(a) provides further support for the conclusion that the provision allows the Secretary to prevent harm by blocking the initiation of air pollution that threatens health or the environment. The provisions of section 65-3012(a) apply "[n]otwithstanding any other provision" of the Kansas Air Quality Act. ${ }^{345}$ This introductory provision indicates that the Secretary's authority to deny air quality permits for the reasons listed in section 65-3008 has no bearing whatsoever on, and does not limit in any way, his authority to address substantial endangerments under section 65-3012(a) through the denial of an air quality permit.

Judicial interpretations of the same language in other contexts support this conclusion. One authority on statutory construction summarizes the applicable precedents this way:

[T] he phrase "notwithstanding any other provision of law" has a special legal connotation. It is considered an express statement of legislative intent that a specific statute in which it is contained control in the circumstances covered by that statute, despite the existence of some other law which might otherwise apply to require a different or a contrary outcome. ${ }^{346}$

Courts construing federal environmental legislation have interpreted "notwithstanding" provisions identical or similar to the one in section 653012(a) in that fashion. In one environmental case, for example, a federal court of appeals interpreted the emergency powers provision of the federal Safe Drinking Water Act. The statute provides that, "[n]otwithstanding any other provision" of the Act, EPA may take such actions as it deems necessary to protect the public health from contaminants that may present an imminent and substantial endangerment. ${ }^{347}$ Relying on the legislative history, the court concluded that "EPA's powers under this provision are 'intended to override any

344. KAN. STAT. ANN. § 65-3012(a) (2002).

345. Id. (emphasis added).

346. 3B Norman J. Singer, Statutes And Statutory Construction $\S 77: 6$ (6th ed. 2003). But cf. Consejo de Desarrollo Economico de Mexicali, A.C. v. United States, 482 F.3d 1157, 1169 (9th Cir. 2007) (stating that the phrase "notwithstanding any other provision of law" is not always construed literally).

347. 42 U.S.C. $\S 300 i(a)(2000)$. 
limitations upon the Administrator's authority found elsewhere" in the statute. $^{348}$

One final aspect of the plain meaning of the statutory text belies the restrictive interpretation of section 65-3012(a) advanced by Sunflower. The reference to an "endangerment" supports the conclusion that the authority delegated to KDHE "to take such action as may be necessary to protect" health and the environment ${ }^{349}$ extends to activities that have not yet begun. The word "endangerment" is inherently future-oriented. To "endanger" is to put in danger or peril or to incur a risk or chance of harm. ${ }^{350}$ Actions that address endangerments necessarily seek to prevent harm that has not yet occurred. Whether that harm stems from an activity that has or has not yet begun would appear to be irrelevant. In either case, the statute delegates to the Secretary the power to do what is necessary to protect health and the environment in the face of the threat.

This straightforward reading of section 65-3012(a) is supported by judicial interpretation of analogous federal environmental statutes. The language of section 65-3012(a) largely tracks the text of various endangerment provisions in the federal statutes. The Kansas provision differs in some respects from the analogous federal provisions. The federal provisions, including the CAA endangerment provision, typically authorize administrative action or judicial relief to deal with an "imminent and substantial endangerment" to health, welfare, or the environment. ${ }^{351}$ The Kansas Air Quality Act omits the word imminent. ${ }^{352}$ If that omission has any significance, it makes the state statute broader in its sweep than the analogous federal statutes because it removes the requirement of temporal proximity. ${ }^{353}$ Under the federal

348. Trinity Am. Corp. v. U.S. EPA, 150 F.3d 389, 395 (4th Cir. 1998) (quoting H.R. REP. No. 93-1185, at 35-36 (1974), as reprinted in 1974 U.S.C.C.A.N. 6454, 6487) (emphasis in original)).

349. KAN. STAT. ANN. § 65-3012(a) (2002).

350. 1 OXFORD ENGLISH, supra note 335 , at 816 (defining endanger).

351. See 42 U.S.C. § 7603 (2000); see also 33 U.S.C. § 1364(a) (2000) (Clean Water Act emergency powers provision); 42 U.S.C. § 300i (Safe Drinking Water Act emergency powers provision); 42 U.S.C. § 6973(a) (Resource Conservation and Recovery Act imminent hazard provision); 42 U.S.C. $§ 9606$ (a) (Comprehensive Environmental Response, Compensation, and Liability Act abatement action provision).

352. As indicated above, one of the bills introduced in the Kansas legislature to overturn Secretary Bremby's decision on the Holcomb plants would have added the requirement that an endangerment be imminent, as well as substantial, to trigger the Secretary's authority under $\S 65$ 3012(a). See supra note 300 and accompanying text. That change clearly was designed to restrict the agency's authority to address endangerments, but the Governor's veto prevented it from becoming law.

353. See Reserve Mining Co. v. EPA, 514 F.2d 492, 528 (8th Cir. 1975), modified, 529 F.2d 181 (8th Cir. 1976) ("The term 'endangering,' as used by Congress in [an early version of the federal Clean Water Act], connotes a lesser risk of harm than the phrase 'imminent and substantial endangerment to the health of persons' as used by Congress in the 1972 amendments to [that 
statutes, an endangerment must be both imminent and substantial to trigger regulatory authority. Under the Kansas statute, it need only be substantial.

Another difference between the Kansas statute and the federal statutes relates to the verb tense. Some of the federal provisions authorize agency or judicial action when specified activities "may present an imminent and substantial endangerment." 354 It is possible to interpret those federal statutes more expansively than the Kansas law because they trigger regulatory authority if the specified activities "may" in the future present an endangerment, even if they do not currently do so. The Kansas statute refers to air pollution emissions that "present" (i.e., now, not in the future) a substantial endangerment.

The absence of the word "may" from the Kansas statute is not a convincing basis for construing its coverage as limited to activities already occurring, however. To begin with, several of the federal imminent hazard provisions cover a pollution source or activity that "is presenting" a substantial endangerment. The CAA's emergency power provision is one example, ${ }^{355}$ and the Clean Water Act is another. ${ }^{356}$ To say that an activity "presents" a danger is the same as saying that the activity "is presenting" the danger. Both are continuous or progressive verb forms. ${ }^{357}$ Yet, the courts have not interpreted these two provisions more narrowly from a temporal perspective than the endangerment and emergency power provisions that are triggered by activities that "may present" an endangerment.

More importantly, the case law recognizes that, as indicated above, ${ }^{358}$ the very concept of an endangerment is inherently futureoriented. One of the early landmark cases in federal environmental law interpreted the meaning of an endangerment. In Ethyl Corp. v. EPA, ${ }^{359}$ industry challenged EPA's issuance of regulations requiring a phase-out of lead additives in motor gasoline. Section 211(c)(1)(A) of the CAA at the time authorized EPA to regulate gasoline additives whose emission

statute].” (citing 33 U.S.C. $§ 1364$ (Supp. 1974))).

354. E.g., 42 U.S.C. $\S 300 \mathrm{i}(2000) ;$ id. § 6973(a). Cf. id. § 9606(a) (authorizing action to abate endangerment attributable to a release of hazardous substances that "may be an imminent and substantial endangerment").

355. 42 U.S.C. $\$ 7603$.

356. 33 U.S.C. $§ 1364(a)$

357. See UsingEnglish.com, Term: Participles, available at http://www.usingenglish.com/ glossary/participles.html (describing the "is [followed by the participle form of a verb]" construction as a continuous or progressive verb form).

358. See supra notes $349-50$ and accompanying text.

359. 541 F.2d 1 (D.C. Cir. 1976) (en banc). 
products "will endanger the public health or welfare."360 EPA issued its phase-out regulations based on a finding that automotive emissions from the use of leaded gasoline presented "a significant risk of harm" to the public health. ${ }^{361}$ Industry attacked the regulations, arguing that the "will endanger" standard required "a high quantum of factual proof, proof of actual harm rather than of a "significant risk of harm." 362 The court disagreed and sustained the regulations. In doing so, it addressed the significance of the term "endanger":

Simply as a matter of plain meaning, we have difficulty crediting petitioners" reading of the "will endanger" standard. The meaning of "endanger" is not disputed. Case law and dictionary definition agree that endanger means something less than actual harm. When one is endangered, harm is threatened; no actual injury need ever occur. Thus, for example, a town may be "endangered" by a threatening plague or hurricane and yet emerge from the danger completely unscathed. A statute allowing for regulation in the face of danger is, necessarily, a precautionary statute. Regulatory action may be taken before the threatened harm occurs; indeed, the very existence of such precautionary legislation would seem to demand that regulatory action precede, and, optimally, prevent, the perceived threat. As should be apparent, the "will endanger" language of Section 211(c)(1)(A) makes it such a precautionary statute. ${ }^{3}$

The precautionary characterization was significant because it allowed the agency to rely upon an expansive range of evidence to justify regulation:

Where a statute is precautionary in nature, the evidence difficult to come by, uncertain, or conflicting because it is on the frontiers of scientific knowledge, the regulations designed to protect the public health, and the decision that of an expert administrator, we will not demand rigorous step-by-step proof of cause and effect. Such proof

360. Id. at 7 (citing 42 U.S.C. $§ 1857 \mathrm{f}-6 \mathrm{c}(\mathrm{c})(1)(\mathrm{A})$ ). The statute has since been amended to authorize EPA to restrict fuel additives that, in the agency's judgment, "may reasonably be anticipated to endanger the public health or welfare." 42 U.S.C. $§ 7545$ (c)(1) (2000). The Kansas statute requires a finding that air pollution "presents a substantial endangerment," rather than that it "will endanger" or "may reasonably be anticipated to endanger" the public health. This difference in terminology does not undercut the relevance of Ethyl Corp. to interpretation of section 65-3012(a). See infra notes 363-65 and accompanying text.

361. Ethyl Corp., 541 F.2d at 7.

362. Id. at 12 .

363. Id. at 13 (footnotes and emphasis omitted). See also id. at 17 (adding "that the "will endanger' standard is precautionary in nature and does not require proof of actual harm before regulation is appropriate"). 
may be impossible to obtain if the precautionary purpose of the statute is to be served. ${ }^{364}$

Thus, a statute that authorizes administrative or judicial action to prevent an "endangerment" is designed to prevent the relevant harm to health before it occurs, rather than to constrain the agency or the court by requiring them to wait until harm has begun before acting. KDHE's denial of the Sunflower permits was based on the Secretary's finding that "emission of air pollution from the proposed coal fired plant, specifically carbon dioxide emissions, presents a substantial endangerment to the health of persons or the environment." ${ }^{" 365}$ That is precisely the kind of finding anticipated by the statute. It is consistent with the thrust of a precautionary statute such as section 65-3012, as the Sunflower permit denial both anticipated a threat of substantial harm from the proposed unit's $\mathrm{CO}_{2}$ emissions and was designed to prevent that harm from occurring.

The statute interpreted in Ethyl Corp. differs somewhat from section 65-3012(a). The CAA provision interpreted by the court in Ethyl Corp. authorized regulation upon a finding that lead additives "will endanger" health or welfare, whereas the Kansas Air Quality Act authorizes KDHE to act when emissions "present[]" an endangerment. This difference creates the possibility that the word "will" in the CAA provision makes it future-oriented in a way that the Kansas statute is not. Under this reading, the CAA's fuel additive provision allowed EPA to stop action before it occurred on the basis of a finding that the action "would" otherwise have endangered health, welfare, or the environment. The Kansas Act thus might require that the activity already be occurring, even if the harm is merely anticipated and has not yet occurred. Under this reading, the Kansas endangerment statute would not apply because the Sunflower plant has not even been constructed yet.

The argument is unconvincing for several reasons. First, lead was already being used in gasoline at the time that EPA issued its regulations so the court had no reason to consider whether the activity already had to be taking place to trigger the CAA's endangerment provision, or whether an activity that had been proposed and that would have contributed to an endangerment if it were to take place would also have been covered. The distinction between ongoing and proposed activities simply was not at

364. Id. at 28 (footnote omitted).

365. Bremby Letter, supra note 4, at 1-2. 
issue, so the court could not have intended to limit its holding to ongoing activities.

Second, another early landmark environmental case interpreting the emergency powers provision of the Clean Water Act undercuts the argument. In Reserve Mining Co. v. EPA, ${ }^{366}$ the United States, several states, and several environmental groups sought an injunction ordering Reserve Mining to stop discharging wastes from its Minnesota iron ore processing plant into the air and into Lake Superior. When the district court ordered that the discharges immediately cease, thus effectively closing the plant, Reserve Mining appealed. ${ }^{367}$ The plaintiffs' request for an order enjoining the water discharges was based on a provision of the Federal Water Pollution Control Act authorizing EPA to request that the Attorney General bring suit to abate water pollution "which is endangering the health or welfare of persons in a state other than that in which the discharge" originated. ${ }^{368}$ Despite the fact that the statute applied to pollution that "is endangering" health or welfare, instead of to pollution that "will endanger" health or welfare, the Reserve Mining court relied on the interpretation of the term "endanger" advanced in the Ethyl Corporation case. ${ }^{369}$ The Eighth Circuit characterized the Ethyl Corporation case as one that involved "a problem analogous to the one now before us," 370 and it "deem[ed] pertinent the interpretation given to the term 'endanger' by Judge Wright of the District of Columbia Circuit in his analysis of the congressional use of the word 'endanger' in the context of a provision of the Clean Air Act." provision interpreted in Ethyl Corporation) applied to activities that "will endanger" health or the environment, while the other (the Clean Water Act provision involved in Reserve Mining) applied to pollution that "is endangering" health or welfare. That distinction, however, did not preclude the court in Reserve Mining from treating the earlier court's

366. 514 F.2d 492 (8th Cir. 1975), modified, 529 F.2d 181 (8th Cir. 1976).

367. Id. at 499 .

368. 33 U.S.C. $\$ 1160(\mathrm{~g})(1)(1970)$ (emphasis added). The current version of that provision is 33 U.S.C. $\S 1364$ (a) (2000), which allows EPA to seek an order to halt a pollution source that "is presenting an imminent and substantial endangerment" to health or welfare from continuing to cause or contribute to the endangerment.

369. Reserve Mining, 514 F.2d at 519-20. Actually, the Eighth Circuit relied upon a dissenting opinion by Judge J. Skelly Wright in a panel opinion in Ethyl Corp. Ethyl Corp. v. EPA, 7 Env't Rep. Cas. (BNA) 1353 (D.C. Cir. 1975). When the case was reheard by the D.C. Circuit en banc, Judge Wright wrote the majority opinion in the version of the case discussed supra notes 359-65 and accompanying text. Judge Wright's earlier dissent contained essentially the same analysis he later advanced in his 1976 majority opinion for the en banc court.

370. Reserve Mining, 514 F.2d at 519.

371. Id. at 528. See also id. at 536 (citing Ethyl Corp. as support for the proposition that "a proper assessment of the health hazard rests upon a proper analysis of the probabilities of harm"). 
interpretation of the applicable scope of the statute as relevant to the scope of the Clean Water Act's endangerment provision. ${ }^{372}$

Third, covering threatened harm from future as well as existing activities is more consistent with the precautionary thrust of environmental endangerment provisions such as the ones at issue in Ethyl Corp. and Reserve Mining and the endangerment provision relied on by Secretary Bremby in denying Sunflower's application. The essential thrust of modern environmental law is to shift the focus from reacting to harm after it occurs to preventing harm before it occurs. Statutory and regulatory environmental law developed in large part because of the perception that traditional common law remedies in suits such as nuisance and trespass provided inadequate protection of public health and environmental values.

Suppose, for example, that the battle over the Sunflower plants had taken the form of a common law nuisance action in which the plant's neighbors sought to enjoin it based on the adverse effects caused by the plant's operation on the plaintiffs' health and property values. The plaintiffs would likely have had a more difficult time prevailing if they brought their suit before the plant was constructed rather than waiting until after it had begun operating. The former situation would likely have been regarded as an anticipatory nuisance action, and the courts traditionally were hesitant to enjoin activities before the fact on the basis of a risk that they might cause harm. ${ }^{373}$

372. None of the substantial endangerment or emergency action provisions of the federal pollution control statutes uses the "will endanger" phraseology anymore. Instead, all allow government action when the regulated activity "is presenting" or "may present" an endangerment or its equivalent. See, e.g., 33 U.S.C. § 1364 (CWA; "is presenting”); 42 U.S.C. § 3001 (Safe Drinking Water Act; "may present"); id. § 6973(a) (RCRA; "may present"); id. § 7603 ("is presenting"); id. § 9606(a) (Comprehensive Environmental Response, Compensation, and Liability Act; "may be" an endangerment). These statutes are all treated as precautionary in nature, whether they use the "is presenting" or "may present" terminology.

373. One writer has described the traditional judicial antipathy to anticipatory nuisance actions as follows:

The judicial disdain underlying anticipatory nuisance is that the plaintiff is asking a court to rule that a proposed use of land is unreasonable before the use actually occurs. This has been referred to as the "despotism" of the anticipatory nuisance concept. This despotism, because it prevents landowners from doing with their land as they please or deem reasonable, makes most courts hesitant to enjoin a proposed action without the plaintiff first meeting a very high burden of proof.

George P. Smith, II, Re-validating the Doctrine of Anticipatory Nuisance, 29 VT. L. REV. 687, 697 (2005) (citations omitted). Serena M. Williams, The Anticipatory Nuisance Doctrine: One Common Law Theory for Use in Environmental Justice Cases, 19 WM. \& MARY ENVTL. L. \& POL'Y REV. 223 (1995), supports the expansion of anticipatory nuisance doctrine to address environmental justice claims. 
It was precisely those kinds of situations that statutory environmental law in general, and, in particular, the endangerment provisions they contained, were designed to address:

The importance of protecting human life and the environment led the 1960s reformers [who helped develop modern environmental law] to reject tort law as the basis of government regulation of technological risks. In a tort system, persons who have been injured by corporate behavior have the burden of initiating expensive legal action to prove that their injury was caused by the defendant's actions. Moreover, someone who anticipates a potential injury usually cannot obtain protection against that risk. Although injunctive relief is theoretically available in actions such as private nuisance to avoid harms alleged to be the imminent result of technological development, the courts are reluctant to enjoin such "anticipatory nuisances" on the basis of the plaintiff's speculation. ...

[Statutory r]isk regulation was a paradigm shift from the common law because Congress authorized regulators to act on the basis of anticipated harm, which permitted regulators to reduce personal and environmental risks despite an "ignorance of mechanism." As John Applegate has pointed out, risk regulation therefore changed the baseline of government regulation in fundamental ways: "Regulation based on risk permits regulatory action based on ex ante collective danger rather than ex post individual injury, and also operates preventively to avert injury to the public as a whole."

The Ethyl Corporation case, decided in 1976, illustrates this new political orientation.... The court determined that EPA could act "before the threatened harm occurs" and that "no actual injury need ever occur." This interpretation was justified because "the very existence of such precautionary legislation would seem to demand that regulatory action precede, and, optimally, prevent the perceived threat.",374

It is of course possible to design a system in which regulatory relief is available to shut down a plant that has been built but that has not yet begun to operate (or has begun to operate but has not yet caused harm), but not a plant that is still in the planning stages. It makes no sense,

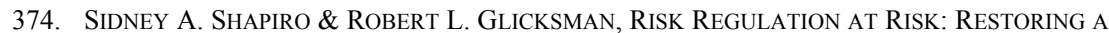
Pragmatic ApProach 5-6 (Stanford University Press 2003) (quoting John S. Applegate, The Perils of Unreasonable Risk: Information, Regulatory Policy, and Toxic Substances Control, 91 Colum. L. ReV. 261, 273 (1991); Ethyl Corp. v. EPA, 541 F.2d 1, 13 (D.C. Cir. 1976) (emphasis in original)). In the same article, Professor Applegate explained that "regulation of risk instead of harm... contrasts with, and is a reaction to, the traditional tort law rule that damages can be recovered only for actual harm or for the definite likelihood of future harm to the individual plaintiff." Applegate, supra, at 271-72. 
however, to allow a plant to be built and only then to shut it down if the inability to operate it without running afoul of the endangerment provision is discernable even before the plant is constructed. Forcing the government to wait until the plant has been built, and perhaps until it has begun operating, not only runs contrary to the precautionary thrust of statutory endangerment provisions, it also puts at risk whatever costs have been sunk into plant construction and the livelihoods of those hired to help operate a plant that is shut down before or shortly after it begins operating. The Kansas courts adhere to the canon that statutes should be construed, if possible, to avoid absurd or unreasonable results. ${ }^{375}$ Requiring KDHE to await the initiation of an activity that it already knows would present a substantial endangerment to health or the environment before it may exercise its authority to protect against the endangerment under section 65-3012 would produce precisely the kind of absurd result that the Kansas courts have long sought to avoid.

The likely reaction of an air pollution source to KDHE's issuance of an abatement order in a manner consistent with Sunflower's narrow interpretation of section 65-3012 only serves to reinforce the flawed nature of the argument that section 65-3012 only allows KDHE to abate ongoing activities. Assume that KDHE were to issue an order under section 65-3012 shutting down a plant that is already built and has begun operating on the ground that its $\mathrm{CO}_{2}$ emissions present a substantial endangerment. Assume further that the source is able to show that KDHE knew before construction commenced that the $\mathrm{CO}_{2}$ emissions it would generate would create a substantial endangerment. Despite that knowledge, KDHE issued an air quality permit (because all of the permitting requirements of section 65-3008 were met). KDHE waited to exercise its authority under section 65-3012 until operations had begun because it lacked the authority to do so earlier. Under those circumstances, the source would likely protest mightily. It might argue, for example, that KDHE's issuance of the permit, and its failure to resort to section 65-3012 to block plant construction, created a reasonable expectation by the source that its operation would comply with the law. As a result, KDHE should be estopped from seeking to prohibit any emissions it knew about when it issued the permit. ${ }^{376}$ Alternatively, the

375. See, e.g., Dillon Real Estate Co. v. City of Topeka, 163 P.3d 298, 310 (2007) (quoting In re M.R., 38 P.3d 694 (Kan. 2002)) ("As a general rule, statutes are construed to avoid unreasonable results.”); Pruter v. Larned State Hosp., 26 P.3d 666, 672 (Kan. 2001) (quoting Landry v. Graphic Tech., Inc., 2 P.3d 758 (Kan. 2000)) ("In interpreting statutes, we must avoid interpretations that would lead to absurd or unreasonable results.").

376. Cf. Kan. City Heartland Constr. Co. v. Maggie Jones Southport Cafe, Inc., 824 P.2d 926, 932-33 (Kan. 1992) (quoting Lines v. City of Topeka, 577 P.2d 42, Syl. \ 4, (Kan. 1978). (“A party 
source might argue that KDHE's invocation of the substantial endangerment statute to block the source's operation after construction was complete amounted to a compensable taking. The argument might be based on the contention that an abatement order under section 653012 frustrated the source's reasonable investment-backed expectations, given KDHE's previous issuance of a permit and its failure to warn the source that its anticipated method of operation would give rise to an abatable endangerment. ${ }^{377}$ These arguments are far from clear winners, ${ }^{378}$ but it is difficult to imagine that the legislature would have wanted the Secretary's substantial endangerment authority to be restricted to situations that necessarily raise these kinds of fairness concerns.

Once again, judicial interpretation of analogous federal environmental statutory provisions cuts against the argument that section 65-3012 is properly read to authorize abatement only of ongoing activities. The portion of the court's opinion in Reserve Mining that deals with the appropriate remedy indicates that courts applying endangerment statutes may be more reluctant to halt ongoing operations than to stop construction of the activity posing the threat before it begins. Although the Eighth Circuit agreed with the district court that the iron ore processing plant was posing an endangerment to the public health, it modified the district court's order requiring immediate cessation of the plant's operation. Instead, it chose to afford the company "a reasonable opportunity and a reasonable time to construct facilities to accomplish an abatement of its pollution of air and water and the health risk created thereby. In this way, hardship to employees and great economic loss incident to an immediate plant closing may be avoided." 379 Assuming

asserting equitable estoppel must show that another party, by its acts, representations, admissions, or silence when it had a duty to speak, induced it to believe certain facts existed. It must also show it rightfully relied and acted upon such belief and would now be prejudiced if the other party were permitted to deny the existence of such facts.").

377. See, e.g., Penn Cent. Transp. Co. v. New York City, 438 U.S. 104 (1978) (declaring that "the extent to which the regulation has interfered with distinct investment-backed expectations are, of course, relevant considerations" in determining whether a regulatory taking has occurred).

378. See, e.g., Kan. City Power \& Light Co. v. State Corp. Comm'n, 715 P.2d 19, $23-27$ (Kan. 1986) (rejecting utility's argument that order of the State Corporation Commission requiring utility to enter into contract to purchase electricity from a cogenerator or small power producer amounted to a compensable regulatory taking); Frontier Ditch Co. v. Chief Eng'r of Div. of Water Res., 704 P.2d 12, 16 (Kan. 1985) (citing In re Moseley's Estate, 164 Pac. 1073 (Kan. 1917); State ex rel. Brewster v. Piper, 176 Pac. 626 (Kan. 1918)) (stating that "there is a long and undeviating line of decisions which hold that laches and estoppel do not operate against the state").

379. Reserve Mining, 514 F.2d at 537. The court added that "[i]n the absence of proof of a reasonable risk of imminent or actual harm, a legal standard requiring immediate cessation of industrial operations will cause unnecessary economic loss, including unemployment, and, in a case such as this, jeopardize a continuing domestic source of critical metals without conferring adequate 
that the government can supply the evidence necessary to demonstrate a "substantial endangerment," therefore, it should be able to take steps to prevent the endangerment even before the activity that poses it is constructed.

In short, the Kansas Air Quality Act on its face authorizes the Secretary of KDHE to take such action, including denial of an air quality permit, under section 65-3012 that he deems necessary to address activities that pose a substantial endangerment to health or the environment, despite the fact that the activities have not yet begun. Even if the statutory text is ambiguous on that point, the evolution of section 65-3012 (especially the 1993 amendments to that provision), judicial interpretations of identical or analogous federal environmental statutes, the canon against interpreting statutes in a manner that produces absurd results, and the outcry that regulated sources would surely raise if the Secretary waited to block a plant until after it has been constructed (despite the Secretary's knowledge of a source's endangering characteristics at the permitting stage), all compel the conclusion that Secretary Bremby's interpretation of the statute is entitled to deference. Bremby's interpretation need not be the same one that a reviewing court would have reached on its own. It need not even be the best interpretation, in the court's view. As long as it has a rational basis-and the analysis in this section demonstrates that Bremby's interpretation does-Kansas judicial precedents require a reviewing court to uphold it. ${ }^{380}$

\section{Actions Addressing "Unregulated" Pollutants}

A second basis for challenging KDHE's authority to rely on section 65-3012 to deny a permit for the Holcomb units rests on the premise that KDHE may not deny a permit based on emissions of a pollutant not already being regulated under federal or state air pollution legislation. ${ }^{381}$

countervailing benefits." Id.

380. See supra notes 312-20 (discussing the doctrine of operative construction).

381. See, e.g., Petition for Judicial Review of KDHE Denial of Permit Application Under K.S.A. $\S 65-3012(\mathrm{a})$, supra note 306 , at 6 (stating that Kansas air quality permitting rules "do not currently contain any restrictions on or other regulations addressing the emission of carbon dioxide" and that "[t]o date, there is no federal or Kansas regulatory program in place that establishes any rule or regulation of general application for the management of carbon dioxide emissions"); see also Petition for Review of KDHE Denial of Permit Application Under K.S.A. § 65-3008a(b), supra note 308 , at 6 ("The Permitting Rules do not currently contain any restrictions on or other regulations addressing the emission of carbon dioxide.").

It is not completely clear that $\mathrm{CO}_{2}$ is actually an unregulated pollutant under federal or state law. The PSD provisions of the CAA require that a facility seeking a construction permit be "subject to 
the best available control technology ... subject to regulation under [the CAA] emitted from... such facility." 42 U.S.C. § 7475(a)(4) (2000). Similarly, "best available control technology" (BACT) means "an emission limitation based on the maximum degree of reduction of each pollutant subject to regulation under [the CAA] emitted from ... any major emitting facility." Id. § 7479(3). At least one dictionary defines "subject to" as "[c]apable of being or liable to be subjected to judgment or test," rather than as actually being liable or covered by a judgment or test. Webster's Online Dictionary, http://www.websters-online-dictionary.org/definition/subject+to (last visited Feb. 19,2008 ). Under this reading of the statute, $\mathrm{CO}_{2}$ is "subject to regulation" under the CAA, even though it is not currently being regulated by EPA, because it is "capable of being" regulated. The Supreme Court in Massachusetts v. EPA held that $\mathrm{CO}_{2}$ qualifies as an air pollutant under the CAA. 127 S. Ct. 1438, 1462 (2007). Additionally, California Attorney General Edmund Brown has asserted that $\mathrm{CO}_{2}$ is a pollutant "subject to regulation" under the CAA and therefore is subject to the BACT requirement. See Brown Letter, supra note 224. Moreover, the definition of BACT requires an agency to consider the overall "energy, environmental, and economic impacts" of a permitted plant. 42 U.S.C. § 7491(3). The environmental impact arguably includes the impact of $\mathrm{CO}_{2}$ emissions.

At least one state agency has rejected the claim that BACT applies to GHG emissions. In May 2007, the Montana Department of Environmental Quality (DEQ) issued an air quality permit to Southern Montana Electric for a 270-megawatt coal-fired power plant near Great Falls. Southern Montana Elec. Generation and Transmission Cooperative, Permit \#3423-00 (May 11, 2007). In doing so, it refused to designate IGCC as BACT for the plant. Id. at 14. It reasoned that GHGs, such as $\mathrm{CO}_{2}$, "are not currently regulated under the Montana or federal [CAA]," so that requiring the use of IGCC would result in "relatively little increased regulated environmental protection." Id. An environmental group, the Montana Environmental Information Center, appealed the permit decision to the state Board of Environmental Review (BER), arguing that the agency is obliged to determine BACT for $\mathrm{CO}_{2}$ because it is " subject to regulation." Montana Environmental Information Center, et al.'s Memorandum in Support of Motion for Summary Judgment, Case No. BER-2007-07 AQ, at 18-19 (Montana Bd. Envtl. Review Nov. 16, 2007) (citing Pub. L. No. 101-549, § 821, 104 Stat. 2399 (1990)). The group argued first that any substance that qualifies as an "air pollutant" under the CAA is "subject to regulation." Id. Second, the group asserted that the 1990 CAA amendments directly regulated $\mathrm{CO}_{2}$ by requiring that utilities covered by the acid deposition control program monitor and report $\mathrm{CO}_{2}$ emissions. Id. Both the permit applicant and the Montana DEQ contested that claim, arguing that interpreting the statute to include all substances that qualify as "air pollutants" as "subject to regulation," whether or not they are actually being regulated, would render the phrase "subject to regulation" superfluous. See Memorandum of Law in Support of Motion for Summary Judgment of Permittee Southern Montana Electric Generation and Transmission Cooperative, Inc., Case No. BER 2007-07 AQ, at 17-20 (Mont. Md. Envtl. Review Nov. 16, 2007) (equating a pollutant that is "subject to regulation" with a "regulated pollutant," and arguing that $\mathrm{CO}_{2}$ is not currently regulated); Department of Environmental Quality's Motion for Summary Judgment and Supporting Brief, Case No. 2007-07 AQ, at 9-10 (Mont. Bd. Envtl. Review Nov. 16, 2007) (citing Ala. Power Co. v. Costle, 636 F.2d 323, 370 n.134 (D.C. Cir. 1979); N. County Res. Recovery Ass'n, 2 E.A.D. 229, 230 (Envtl. Appeals Bd. 1986)). In early 2008, the BER affirmed the DEQ's decision, concluding that BACT did not apply to $\mathrm{CO}_{2}$ because it is not a regulated pollutant. See Karl Puckett, Board Rejects Appeal of Highwood Air-Quality Permit, GrEat Falls TRIB., Jan. 12, 2008, at A1; Dennison, supra note 112.

After reviewing the two conflicting interpretations of the scope of BACT, Professor Stensvaag asserts that "it has long been settled that the BACT requirement of the PSD program applies only to those pollutants currently being regulated by EPA." John-Mark Stensvaag, Preventing Significant Deterioration Under the Clean Air Act: New Facility Permit Triggers, 38 ENVTL. L. ReP. 10003, 10009 (2008). Cf. 40 C.F.R. $\S 51.166(\mathrm{~b})(12)$ (2006) (emphasis added) (EPA PSD regulation defining "best available control technology" as "an emissions limitation ... based on the maximum degree of reduction for each regulated [new source review] pollutant which would be emitted from any proposed major stationary source or major modification"). EPA's Environmental Appeals Board does not consider the matter settled. It refused to address the issue of whether $\mathrm{CO}_{2}$ is a pollutant "subject to regulation" for purposes of the PSD permit program in In re Christian County Generation, L.L.C., PSD Appeal No. 07-01 (Jan. 28, 2008), because the party alleging that it is 
Neither EPA regulations under the CAA nor KDHE regulations under the Kansas Air Quality Act restrict $\mathrm{CO}_{2}$ emissions from stationary sources. If, therefore, KDHE may only take steps to abate an endangerment caused by the emission of regulated air pollutants, Secretary Bremby's denial of the Sunflower permits would be unauthorized.

This argument is no more compelled by the plain meaning of the Kansas endangerment provision than is the contention that KDHE may only take steps to abate a substantial endangerment under section 653012 if the activity responsible for causing it is already taking place. To the contrary, the clear language of the statute does not support it. Section 65-3012(a) authorizes KDHE to take actions it deems necessary to protect health and the environment "[u]pon receipt of information that the emission of air pollution presents a substantial endangerment" to health or the environment. ${ }^{382}$ The Act defines "air pollution" to mean "the presence in the outdoor atmosphere of one or more air contaminants in such quantities and duration as is, or tends significantly to be, injurious to human health or welfare, animal or plant life, or property, or would unreasonably interfere with the enjoyment of life or property.",383

failed to raise the issue during the public comment period on a draft permit. In doing so, it remarked that before Massachusetts v. EPA, "there was no 'strong precedent' in the federal courts" that was contrary to the position that $\mathrm{CO}_{2}$ qualifies as a pollutant "subject to regulation." Id. at 14 n.18. It added that "[w]hether $\mathrm{CO}_{2}$ is a pollutant 'subject to regulation' under the [CAA] remains a matter of considerable dispute." Id. at 17. Finally, it noted that the issue was pending in another case, In re Deseret Power Elec. Coop., PSD Appeal No. 07-03 (Nov. 21, 2007) (Order Granting Review). Id. at 15-16. See Steven D. Cook, EPA Permit for Utah Coal-Fired Power Plant Under Challenge at Agency's Appeals Board, 39 ENV'T REP. (BNA) 344, Feb. 22, 2008 (discussing Deseret Power case); In re Deseret Power Elec. Coop., PSD Appeal 07-03, 2008 WL 902877 (E.A.B. Mar. 30, 2008) (scheduling oral argument in the case).

KDHE's air quality regulations also arguably are expansive enough to cover $\mathrm{CO}_{2}$, at least in certain instances. For example, the air quality regulations provide that any person who proposes to construct or operate a stationary source who is not otherwise required to obtain a construction permit must nevertheless obtain approval from KDHE to commence construction if KDHE determines that "any other air contaminant emissions from the ... stationary source may cause or contribute to air pollution within the state because of its specific chemical or physical nature or because of the quantity discharged ...." KAN. ADMIN. REGS. § 28-19-300(b)(2) (2006). As the discussion below indicates, $\mathrm{CO}_{2}$ emissions qualify as "air pollution" under the Kansas Air Quality Act. See infra notes 383-426 and accompanying text. See also KAN. ADMIN. REGS § 28-19-301(e) (stating that construction permits "may be conditioned upon compliance by the owner or operator with any special restrictions that are deemed necessary to insure compliance with these regulations or otherwise prevent air pollution" (emphasis added)).

382. KAN. STAT. ANN. § 65-3012(a) (2002).

383. Id. $\S 65-3002$ (c). The reference to air contaminants that "tend" to be injurious also supports the conclusion above that the endangerment provision may be triggered by activities and air pollution that have not yet begun. An air contaminant may qualify as "air pollution" on the basis of its tendency to cause harm generally, even if it has not done so in the particular context being addressed under the endangerment provision. Moreover, the ability of "tendencies" to trigger regulatory authority is reflective of the precautionary nature of the state air quality statute. 
An "air contaminant" means "dust, fumes, smoke, other particulate matter, vapor, gas, odorous substances, or any combination thereof, but not including water vapor or steam condensate." ${ }^{384} \mathrm{CO}_{2}$ is a gas (one of the GHGs responsible for contributing to climate change), so it clearly qualifies. The explicit exclusion of water vapor or steam condensate indicates that the fact that a substance emitted from a plant is one that is already present naturally in the ambient air does not take it outside the definition of an air contaminant. If that were so, the exclusion would be unnecessary. ${ }^{385}$ In addition, the statute refers to "any combination" of the listed substances. The Supreme Court relied in part on the inclusion of the word "any" in the CAA's definition of an "air pollutant" to support its conclusion that GHGs qualify as air pollutants under the CAA's "capacious" definition of that term. ${ }^{386}$

Assuming that $\mathrm{CO}_{2}$ is an "air contaminant," its emission from a coalfired power plant qualifies as "air pollution" as long as it is emitted "in such quantities and duration as is, or tends significantly to be, injurious to human health or welfare, animal or plant life, or property . ..."387 The various ways in which $\mathrm{CO}_{2}$, as the principal GHG, is injurious to health, welfare, animal and plant life, and property have been documented by countless scientific studies. Professor Lisa Heinzerling has identified, for example, the myriad ways in which climate change caused by GHG emissions may adversely affect the public health:

More frequent and intense heat waves are only one item on the long list of the consequences of climate change that will harm human health. According to the latest scientific research, we can expect the following in our warming world: disease-carrying insects will alter their ranges, appearing in places they have not been before and where humans have not developed immunities, causing more widespread incidence of vectorborne diseases such as malaria; after a slight uptick, crop productivity will decline, causing a concomitant increase in the risk of malnutrition; fish stocks will deteriorate, to the same effect; ground-

384. Id. § 65-3002(a).

385. This interpretation of the statute is supported by the well-known canon of statutory interpretation expressio unius. The Kansas Supreme Court has described the maxim as follows: "When an item is not included in a specific list, this court can presume that the legislature intended to exclude the item by applying the maxim of expressio unius est exclusio alterius, i.e., the inclusion of one thing implies the exclusion of another." Cole v. Mayans, 80 P.3d 384, 393-94 (Kan. 2003). Because the statutory list of naturally occurring substances that do not qualify as air contaminants does not include $\mathrm{CO}_{2}$, a presumption arises that the Kansas legislature did not intend to exclude $\mathrm{CO}_{2}$, another naturally occurring substance, from the definition of an air contaminant.

386. Massachusetts v. EPA, 127 S. Ct. 1438, 1460, 1462 (2007) (““[A]ny’ . . has an expansive meaning, that is, one or some indiscriminately of whatever kind"' (citing Dep't of Housing \& Urban Dev. v. Rucker, 535 U.S. 125, 131 (2002)).

387. KAN. StAT. ANN. § 65-3002(c). 
level ozone will worsen, causing adverse pulmonary and cardiovascular events; water supplies will decrease due to reduced snowpack and increased drought; ${ }^{388}$ storms will become more frequent and severe, threatening Katrinalike consequences for human health and welfare; flooding will grow more frequent and severe due to storms and sea level rise; ${ }^{389}$ diarrhoeal disease will increase due to floods and drought; cholera will grow more frequent and toxic due to higher water temperatures; sanitation facilities will fail more often due to more frequent extreme weather events, leading to increased spread of infectious diseases; ozone depletion will worsen with a changing climate, leading to increased incidence of skin cancer, cataracts, and immune deficiency; increased pollen production will exacerbate allergies; hunger and malnutrition will rise due to drought and extreme weather events.

Reviewing this list, it appears that there is almost no component of human health that will be untouched by climate change. And the list does not end here. The shrinking resource base of a warming world will also increase the likelihood of refugee crises, violent conflicts, and even wars. 390

388. According to EPA, continued warming could exacerbate water shortages in western Kansas and lead to reductions in groundwater levels as withdrawals increase. Even in the eastern part of the state, where water supplies are more abundant, lower stream flows could compromise uses of reservoirs for municipal and industrial supply, fish and wildlife habitat, recreation, and irrigation. Lower flows and higher temperatures also could impair water quality by increasing pollutant concentration levels. U.S. Envtl. Prot. Agency, Climate Change and Kansas 3, EPA 236-F-98-0071 (Sept. 1998) [hereinafter Climate Change and Kansas].

389. EPA noted that more than one-half of the communities in Kansas have flood-prone areas. It added that harder rains could increase erosion and exacerbate runoff from mining and agricultural activities. Id.

390. Lisa Heinzerling, Climate Change, Human Health, and the Post-Cautionary Principle, 96 Geo. L.J. 445, 448 (2008) (citing Intergovernmental Panel on Climate Change, Climate CHANGE 2007: IMPACTS, ADAPTATION, AND VULNERABILITY, WORKING GROUP II CONTRIBUTION to the Intergovernmental Panel on Climate Change Fourth Assessment Report, SUMMARY FOR POLICYMAKERS 7-9 (2007)).

EPA also has recognized that climate change is likely to affect the public health adversely. Citing IPCC studies, EPA has found that the expected "key impacts" of climate change in North America will include adverse impacts on human health:

[C]limate change impacts on infrastructure and human health and safety in urban centers will be compounded by aging infrastructure, maladapted urban form and building stock, urban heat islands, air pollution, population growth and an aging population....

Severe heat waves are projected to intensify in magnitude and duration over the portions of the U.S. where these events already occur, with likely increases in mortality and morbidity, especially among the elderly, young and frail. Ranges of vector-borne and tick-borne diseases in North America may expand but with modulation by public health measures and other factors. $\cdots$

The IPCC projects with virtual certainty declining air quality in U.S. and other world cities due to warmer and fewer cold days and nights and/or warmer/more frequent hot days and nights over most land areas. Climate change is expected to lead to increases in 
According to Professor Heinzerling, "[t]he human health consequences of climate change are not just worries for the remote future; they are happening here and now."391 Examples of the immediacy of the impacts of climate change appear in the press with some frequency. Physicians at the World Health Organization's Health and Environment Program, for example, attributed an outbreak in 2007 of chikungunya, a tropical disease that is similar to dengue fever, in Castiglione di Cervia, Italy to climate change. The disease is spread by tiger mosquitoes, which previously had been unable to live outside of the tropics. As temperatures warmed in Italy, however, portions of the country became hospitable to the mosquitoes. The result was the appearance and spread of a disease that had never before occurred in Italy. ${ }^{392}$

Much closer to home, a December 2007 report issued by the Pew Center for Climate Change discussed several case studies of the likely impacts of climate change on different regions of the United States. ${ }^{393}$ One of the case studies involved the impact of climate change on heatwaves in the Midwest. The report concluded that, under a "business as usual" scenario in which little policy intervention to mitigate GHG emissions occurs, the midwestern United States is likely to experience an increase in the average frequency and duration of heatwaves this century. As one example, the study projected that the average frequency of heatwaves would increase by $36 \%$ in St. Louis and the average duration would increase by $38 \%$ there. ${ }^{394}$ Among those most vulnerable to heat cramps, heat exhaustion, heatstroke, and death as a result of these

ozone pollution, with associated risks in respiratory infection and aggravation of asthma. Ozone exposure also may contribute to premature death in people with heart and lung disease.

U.S. Envtl. Prot. Agency, California State Motor Vehicle Pollution Control Standards; Notice of Decision Denying a Waiver of Clean Air Act Preemption for California's 2009 and Subsequent Model Year Greenhouse Gas Emission Standards for New Motor Vehicles, 73 Fed. Reg. 12,156, 12,167 (Mar. 6, 2008) (footnotes omitted).

391. Heinzerling, supra note 390 , at 449 .

392. See Elisabeth Rosenthal, Editorial, As Earth Warms Up, Virus from Tropics Moves to Italy, N.Y. Times, Dec. 23, 2007, at A16. Cf. Nils Chr. Stenseth et al., Plague: Past, Present, and Future, 5 PLoS MEDICINE, no. 1 (Jan. 15, 2008), available at http://medicine.plosjournals.org/ perlserv/?request=get-document\&doi=10.1371/journal.pmed.0050003 (finding that warmer springs and wetter summers increase the prevalence of plague in its main host, the great gerbil, and that those conditions might become more common in the future). For discussion of the impact of climate change on infectious and respiratory diseases, see generally CENTER FOR HEALTH AND THE GLOBAL Environment, Harvard Medical School, Climate Change Futures: Health, Ecological AND ECONOMIC DiMENSIONS 32-52 (P. Epstein \& E. Mills eds., 2005).

393. Kristine L. EBI et AL., Regional IMPACtS of Climate Change: Four CASE StUdies IN THE UNITED STATES (2007), available at http://www.pewclimate.org/regional_impacts.

394. Id. at 14 . 
heatwaves are the elderly, babies and infants, people taking certain prescription medications (such as beta-blockers), the physically unfit, those engaged in vigorous exercise outdoors, overweight individuals, urban populations, those of lower socio-economic status, and people living alone. ${ }^{395}$ An earlier report by EPA estimated that if temperatures increase by $4^{\circ} \mathrm{F}$, the number of heat-related deaths in Kansas City in the summer could increase by $150 \% .^{396}$ The same report raised the possibility that warming temperatures could increase the incidence of Lyme disease and other tick-borne diseases and rodent infestations in Kansas. The spread of malaria is even possible if that disease is introduced in Kansas and climate changes make the environment conducive to the growth of mosquito populations. ${ }^{397}$

Similarly, myriad studies document the likely adverse impacts of climate change on other components of the statutory definition of "air pollution." One recent study found that, even using conservative assumptions, losses to non-human life may amount to hundreds of billions of dollars annually. ${ }^{398}$ A study released in 2007 reported that $\mathrm{CO}_{2}$-induced enhancement of plant growth suggests that rising atmospheric $\mathrm{CO}_{2}$ may be contributing to the encroachment of shrubs into grasslands. If so, this shift may create difficulties for rangeland managers and ranchers as grasses, the preferred forage of domestic livestock, are replaced by species that are unsuitable for domestic livestock grazing. ${ }^{399}$ Property damage is also likely as a result of the increased frequency and severity of violent weather events to which climate change may give rise. ${ }^{400}$

The Kansas Air Quality Act confines the definition of "air pollution" to the presence of air contaminants "in such quantities and duration as is, or tends significantly to be injurious" to the identified components of

395. Id. at 8-11. See also IPCC SYNTHESIS REPORT, supra note 17, at 10 (finding that during the 21 st century sites in North America "that currently experience heatwaves are expected to be further challenged by an increased number, intensity and duration of heatwaves..., with potential for adverse health impacts").

396. Climate Change and Kansas, supra note 388, at 2-3.

397. Id. at 3 .

398. Wayne Hsiung \& Cass R. Sunstein, Climate Change and Animals, 155 U. PA. L. REv. 1695, 1699 (2007). For examples of the kinds of species that are at risk, see GLICKSMAN ET AL., supra note 283 , at $559-60$.

399. See Morgan et al., Carbon Dioxide Enrichment Alters Plant Community Structure and Accelerates Shrub Growth in the Shortgrass Steppe, 104 GeOPHYSICAL RESEARCH LTRS. 14724 (Sept. 11, 2007).

400. See IPCC SYNTHESIS REPORT, supra note 17, at 12 (listing pressures on rural and urban infrastructures and property loss as very likely to result due to heavy precipitation events). 
society. ${ }^{401}$ One argument that $\mathrm{CO}_{2}$ from a coal-fired power plant such as the Holcomb units does not qualify as air pollution is that the emissions from one such plant, in and of themselves, are not likely to be injurious to health or the environment. Litigants have advanced various versions of this argument in past environmental cases, and it typically meets with a hostile judicial reception. In Ethyl Corp. v. EPA, for example, the industries challenging EPA's lead phase-out regulations argued that EPA could only regulate fuel additives such as lead under the CAA's "will endanger" standard if it could prove that "the emission product of the additive to be regulated 'in and of itself,' i.e., considered in isolation, endangers health."402 EPA responded that the statute allowed it to base its regulatory determinations on the impact of lead emissions from the burning of automotive fuel together with all other human exposure to lead. ${ }^{403}$

The challengers based their argument in part on the absence of words such as "contribute to" an endangerment, which were present in other provisions of the CAA. ${ }^{404}$ The D.C. Circuit, which rejected industry's argument, responded that none of the relevant provisions of the statute made it clear whether emissions appropriately could be regarded as endangering health "when the endangerment is not caused by that pollution alone." 405 In that case, EPA's Administrator found an endangerment sufficient to justify the phase-out of lead additives, despite concluding that health problems due to lead exposure were being caused, "not by air pollution alone, but by an aggregate of sources, including food, water, leaded paint, and dust. He believed that regulation was justified because the aggregate was dangerous, and because leaded gasoline was a significant source that was particularly suited to ready reduction. ${ }^{\text {"406 }}$ The court deferred to the agency's approach,

particularly in light of the realities of human exposure to lead and what Congress knew about those realities. Such consideration demonstrates both that, under Ethyl's approach, EPA regulation of lead on health grounds would be impossible and that Congress could not possibly have intended the restrictive "by itself" reading. ... [L]ead enters the human body from multiple sources, so that the effect of any one source is meaningful only in cumulative terms .... Under Ethyl's approach,

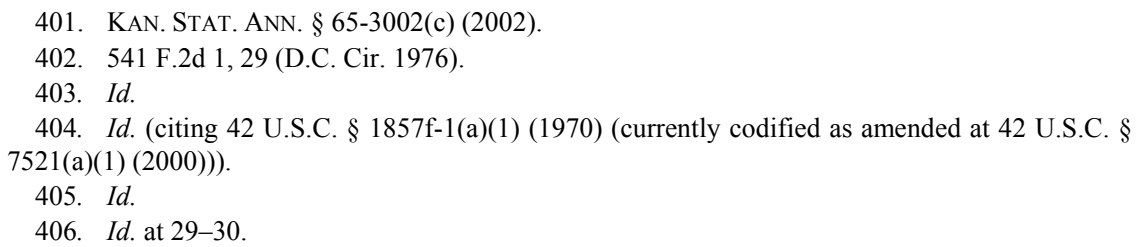


despite obvious endangerment such a cumulative finding is insufficient to justify regulation. Airborne lead, in and of itself, may not be a threat. But the realities of human lead exposure show that no one source in and of itself (except possibly leaded paint) is a threat. Thus, under Ethyl's tunnel-like reasoning, even if parallel legislation permitted regulation of other sources of lead exposure, which it does not, no regulation could ever be justified. ${ }^{4}$

The court refused to endorse a reading of the statute so at odds with not only the physical realities of the way pollution works, but also with the purposes of the statute. The court held that EPA's cumulative impact approach was not erroneous. ${ }^{408}$

Similarly, it makes no sense to require that a stationary source emitting $\mathrm{CO}_{2}$ be responsible for a quantity of emissions that, by itself, is or tends to be injurious to health or welfare. Under that test, no source could ever be regulated, given the minimal contribution that any one source makes to the worldwide climate change problem.

Further support for rejecting such a "tunnel-like" reading of the Kansas Air Quality Act's substantial endangerment provision comes from the Supreme Court's decision in Massachusetts v. EPA. ${ }^{409}$ One of the arguments EPA made in that case was that the state lacked standing to sue. ${ }^{410}$ A plaintiff seeking to show that it has standing to sue under Article III of the Constitution must show that it has or imminently will suffer injury in fact that is fairly traceable to the defendant, and that it is likely that a favorable decision will redress that injury. ${ }^{411}$ EPA asserted that, even assuming that the state showed the requisite injury, it could not possibly demonstrate causation and redressability because its decision not to regulate GHGs from new motor vehicles contributes so insignificantly to those injuries that the climate change-related injuries (such as the loss of coastal property due to melting glaciers and rising sea levels) were not "fairly traceable" to that decision. ${ }^{412}$ Similarly, EPA claimed that there was no realistic possibility that the relief sought would

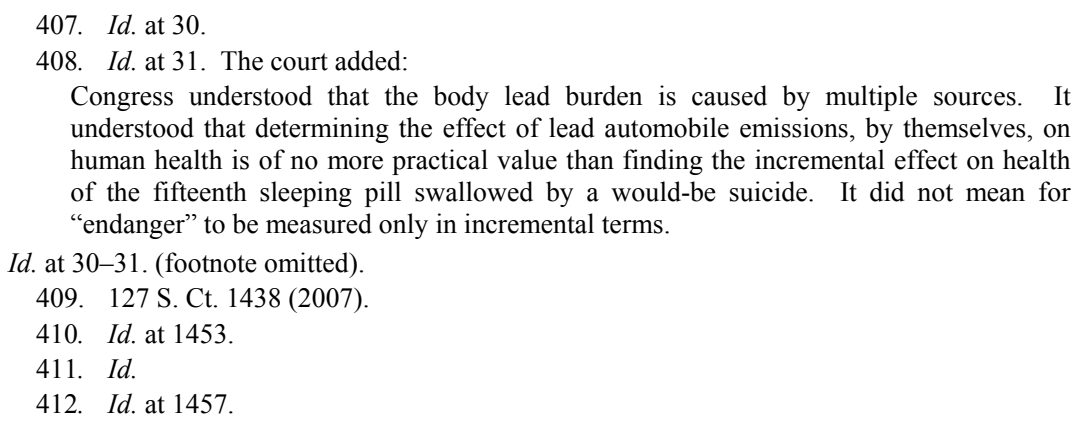


mitigate global climate change and remedy the state's injuries. ${ }^{413}$ The majority rejected the agency's attempt to keep the case out of court because its

argument rests on the erroneous assumption that a small incremental step, because it is incremental, can never be attacked in a federal judicial forum. Yet accepting that premise would doom most challenges to regulatory action. Agencies, like legislatures, do not generally resolve massive problems in one fell regulatory swoop.

On analogous reasoning, it would be inappropriate to adopt a reading of the Kansas endangerment statute that conditions KDHE's authority to abate $\mathrm{CO}_{2}$ emissions on a showing that the targeted activities by themselves are or would be responsible for a quantity or duration of emissions that, without regard to other sources of $\mathrm{CO}_{2}$, would cause climate change-related risks.

The plain meaning of the endangerment provision undercuts in yet another way the argument that KDHE may not use that provision to restrict emissions of a pollutant, such as $\mathrm{CO}_{2}$, that is not already being regulated under some existing federal or state regulatory program. The statute authorizes the Secretary to take necessary actions to protect health and the environment from emissions that present a substantial endangerment, "[n]otwithstanding any other provisions of this act." On its face, that provision allows KDHE to target emissions of air pollution that present the requisite endangerment, no matter what kind of regulation is or is not already taking place under other provisions of the statute. The agency's endangerment authority thus stands on its own, and is not dependent on the status of $\mathrm{CO}_{2}$ under any other regulatory program. ${ }^{416}$

This reading of section 65-3012(a) is again reinforced by federal judicial interpretation of the substantial endangerment provisions of the federal pollution control laws. A good example is the Fourth Circuit's decision in United States $v$. Waste Industries, Inc. ${ }^{417}$ EPA brought suit in federal district court to force the owners of a landfill that was polluting nearby waters to abate alleged threats to the public health and the

\footnotetext{
413. Id.

414. Id.

415. KAN. StAT. ANN. § 65-3012(a) (2002).

416. See supra note 346 and accompanying text (describing the "special legal connotation" afforded by the courts to statutory "notwithstanding" clauses like the one in $\S 65-3012(a)$ ).

417. 734 F.2d 159 (4th Cir. 1984).
} 
environment posed by hazardous chemicals leaking from the site. ${ }^{418}$ After the district court dismissed the action, EPA appealed. ${ }^{419}$ The government relied on the endangerment provision of the Resource Conservation and Recovery Act ("RCRA"). ${ }^{420}$ The landfill argued, and the district court agreed, that the endangerment provision did not authorize an order requiring corrective action because it applied only to the wastes themselves before or as they are produced, and not to conditions, such as contamination of nearby water supplies, resulting when the wastes leaked out of the landfill. ${ }^{421}$ The Fourth Circuit was not persuaded. The court found that " $[t]$ he fallacy of that contention is demonstrated by the indication of Congress that ... remedies [under the endangerment provision] exist apart from the other provisions in the Act's structure ... [and] is designed to deal with situations in which the regulatory schemes break down or have been circumvented." ${ }^{422}$ The court added that the endangerment provision applied to the leakage, "whether or not those engaging in the endangering acts are subject to any other provision of the Act. Its application 'notwithstanding any other provision of this chapter' indicates a congressional intent to include a broadly applicable section dealing with the concerns addressed by the statute as a whole." 423 The court construed the endangerment provision as

a congressional mandate that the former common law of nuisance, as applied to situations in which a risk of harm from solid or hazardous wastes exists, shall include new terms and concepts which shall be developed in a liberal, not a restrictive, manner. This ensures that problems that Congress could not have anticipated when passing the Act will be dealt with in a way minimizing the risk of harm to the environment and the public. ${ }^{42}$

\footnotetext{
418. Id. at 161

419. Id.

420. The statute provided:

Notwithstanding any other provision of [the statute], upon receipt of evidence that the handling, storage, treatment, transportation or disposal of any solid waste or hazardous waste may present an imminent and substantial endangerment to health or the environment, the Administrator may bring suit on behalf of the United States in the appropriate District Court to immediately restrain any person contributing to such handling, storage, treatment, transportation or disposal to stop such handling, storage, treatment, transportation or disposal or to take such other action as may be necessary.

Id. at 163-64 (citing 42 U.S.C. § 6973 (1980)).

421. Id. at 164 .

422. Id

423. Id.

424. Id. at 167.
} 
At about the same time, a federal district court, interpreting the same endangerment provision, found "that the imminent hazard provision of section 6973 does indeed impose liability, distinct from that imposed by any other RCRA provision, on those contributing to activities that may present an imminent and substantial endangerment," and that "the primary purpose of section 6973(a) is to impose liability on any person who, although complying with all other provisions of RCRA, conducts activities that contribute to an imminent hazard." 425 Other federal courts have interpreted the endangerment provisions of the pollution control statutes along similar lines. ${ }^{426}$ These cases support the conclusion that the substantial endangerment provision of section 65-3012 operates as a gap-filling provision to enable KDHE to address environmental problems that the legislature could not have anticipated or did not anticipate when it adopted the Air Quality Act but that, if left unregulated, would threaten to thwart the health and environmental concerns addressed by the statute as a whole.

\section{Conclusion on Statutory Authority Issues}

The analysis in this section has developed the argument that the substantial endangerment provision of the Kansas Air Quality Act empowers KDHE to deny a construction permit for a coal-fired power plant even though the basis for the finding of endangerment is the projected emissions that the plant would generate if it were allowed to operate, rather than emissions that are already occurring. The analysis above also supports the conclusion that it makes no difference that $\mathrm{CO}_{2}$ is not currently being regulated under other provisions of federal or state air pollution control law. The endangerment provision stands on its own as an independent source of regulatory power.

425. Jones v. Inmont Corp., 584 F. Supp. 1425, 1433-34 (S.D. Ohio 1984), reconsideration denied, 22 Env't Rep. Cas. (BNA) 1447 (S.D. Ohio 1984).

426. See, e.g., Interfaith Cmty. Org. v. Honeywell Int'l, Inc., 399 F.3d 248, $260-61$ (3d Cir. 2005) (concluding that the same substantial endangerment provision applied even though there was no applicable state remedial standard for river sediment chromium, and that "[p]roof of contamination in excess of state standards may support a finding of liability, and may alone suffice for liability in some cases, but its required use is without justification in the statute"); Trinity Am. Corp. v. U.S. EPA, 150 F.3d 389, 395 (4th Cir. 1998) (quoting H.R. REP. No. 93-1185, at 35-36 (1974), as reprinted in 1974 U.S.C.C.A.N. 6454, 6487) ("EPA's powers under [the substantial imminent and endangerment provision of the Safe Drinking Water Act, [42 U.S.C. § 300i(a) (2000), ] are 'intended to override any limitations upon the Administrator's authority found elsewhere' in the Act"). 
In his opinion, the Kansas Attorney General found no appellate court decisions construing the substantial endangerment statute. ${ }^{427} \mathrm{He}$ also found that the statute "is plain and unambiguous" and that it supports the denial of an air quality permit for a proposed coal-fired power plant that would emit $\mathrm{CO}_{2}$, despite the absence of federal or state regulations restricting $\mathrm{CO}_{2}$ emissions. ${ }^{428}$ As at least one Justice of the Supreme Court has noted, "ambiguity is apparently in the eye of the beholder." 429 Not everyone would therefore necessarily agree that the statute is "plain and unambiguous" and that the arguments advanced above in support of the Secretary's (and the Attorney General's) position are self-evident.

The burden of proof in any challenge to Secretary Bremby's decision, however, is on the challenger. ${ }^{430}$ Because the issues discussed above involve the validity of an administrative agency's statutory interpretations, the doctrine of operative construction applies. As a result, under existing Kansas precedents, KDHE's construction of the substantial endangerment provision is entitled to deference, particularly given the agency's "special competence and expertise." 431 As long as KDHE's interpretation has a rational basis, it should survive a judicial challenge, even if it is not the same interpretation that a court would have reached in the first instance. ${ }^{432}$ The analysis here demonstrates the extent to which the Secretary's interpretation is supported by existing judicial precedents construing analogous statutory provisions, as well as being consistent with the plain language of section 65-3012 and the policies reflected in the Kansas Air Quality Act. It is therefore difficult to conclude that the agency's interpretation is irrational. It is more difficult still to sustain the contention that the denial of the Sunflower permits represents government by "administrative fiat" 433 or that "the executive branch [made] up the rules" ${ }^{434}$ without any legislative foundation in a manner that comprises a grave challenge to separation of powers principles.

\footnotetext{
427. AG Opinion, supra note 233 , at 2 .

428. Id.

429. Exxon Mobil Corp. v. Allapattah Servs., Inc., 545 U.S. 546, 572 (2005) (Stevens, J., dissenting).

430. See supra note 310 and accompanying text.

431. See supra notes $316-17$ and accompanying text.

432. See supra note 380 and accompanying text.

433. See supra note 275 and accompanying text.

434. See supra note 209 and accompanying text.
} 


\section{B. Statutory Implementation Challenges}

Sunflower also has challenged KDHE's denial of the Sunflower permit on the ground that the agency has applied the substantial endangerment statute improperly. This challenge is based on the charge that, even assuming the statute authorizes regulation of new sources of air pollution, and even assuming it applies to substances (such as $\mathrm{CO}_{2}$ ) not already being regulated as air pollution under other statutory or regulatory provisions, the Secretary's conclusion that a permit denial was necessary to prevent the Holcomb units' $\mathrm{CO}_{2}$ emissions from presenting a substantial endangerment was not based on substantial evidence in the record. ${ }^{435}$ Because of the nature of such a challenge, it is even less likely to succeed than the claims that KDHE misinterpreted the statute.

\section{Standard of Review}

The scope of review of a challenge to the manner in which an agency applies a statute whose meaning is not in dispute is governed by the judicial review statute. A court is authorized to invalidate agency action if the agency has erroneously applied the law, based its action on a determination of fact that is not supported by substantial evidence "when viewed in light of the record as a whole," or otherwise acted in an unreasonable, arbitrary, or capricious manner. ${ }^{436}$

Like review of an agency's statutory interpretations, judicial review of a challenge based upon alleged factual errors or arbitrary and capricious decisionmaking is deferential. Indeed, the relative competence of agencies and courts in the two contexts would seem to support at least as much deference to an agency's statutory implementation as to its statutory interpretation. ${ }^{437}$ A primary task of

435. See Sunflower Elec. Power Corp. v. Kan. Dep't of Health \& Env't, Petition for Judicial Review of KDHE Denial of Permit Application Under K.S.A. § 65-3012(a), supra note 306, at 11 (claiming the "[o]rder is invalid because it is based upon purported determination affect [sic] that is not supported by evidence"); Sunflower Elec. Power Corp. v. Kan. Dep't of Health \& Env't, Petition for Review of KDHE Denial of Permit Application Under K.S.A. § 65-3008a(b), supra note 308, at $9-10$.

436. Kan. STAT. ANN. § 77-621(c)(4), (7), (8) (1997).

437. Professor Charles Koch explained the appropriate degrees of deference to different kinds of agency determinations:

The restraints on review of policymaking and fact-finding should not diminish the judicial authority over questions of law. This principle is well established in general legal theory as well as in administrative law. Since Marbury v. Madison, the courts have dominated questions of law. Administrative law has long recognized judicial dominance over questions of law as agencies have administrative dominance over questions of policy.... 
courts is to interpret statutes, so review of an agency's interpretation of a statute does not require courts to engage in tasks that are foreign to them. Courts also engage in fact-finding, but agencies typically have greater expertise in making factual determinations and mixed determinations of fact and policy ${ }^{438}$ in their areas of substantive expertise than courts do. ${ }^{439}$ As the U.S Supreme Court has stated, "a reviewing court must generally be at its most deferential" when reviewing the validity of an agency's scientific determinations that involve "making predictions, within [the agency's] area of special expertise, at the frontiers of science[,] ... as opposed to simple findings of fact." 440 If a court were to evaluate KDHE's determination that emissions from the Holcomb units presented a substantial endangerment, it would have to assess the scientific determinations and predictions that KDHE made (relying in part on the expertise of the IPCC) $)^{441}$ concerning the impact of $\mathrm{CO}_{2}$ emissions on health and the environment. It would also have to assess the mixed factual and policy determinations that the particular level of risk involved in allowing operation of the Holcomb units qualified as a substantial endangerment, and that denial of a permit was "necessary" to protect health and the environment in the face of that endangerment. These are the kinds of determinations that typically receive considerable judicial deference. ${ }^{442}$

Nothing should diminish the "well-established principle of administrative law" that in reviewing the bundle of issues that comprise an administrative decision the agency's determination is dominant as to policy but not as to law.

Charles H. Koch, Jr., An Issue-Driven Strategy for Review of Agency Decisions, 43 ADmIN. L. ReV. 511, 532-33 (1991).

438. See, e.g., id. at 516 ("Policymaking implicates all the aspects of expertise. Administrative agencies ... have a special claim on expertise. Foremost, tasks are assigned to the administrative process rather than the courts because agencies embody special expertise. Thus an agency's policymaking expertise constitutes a conscious allocation of functions cautioning the courts against undue interference.").

439. See Michael Asimow, The Scope of Judicial Review of Decisions of California Administrative Agencies, 42 UCLA L. REV. 1157, 1218 (1995):

Deference is particularly appropriate when the agency has a comparative advantage over the court in applying law to facts. In particular, agencies may be more competent to apply legal standards to the basic facts where the case falls into the administrative routine and the legal standard is relatively indeterminate. In this situation, an agency's competence arises out of the twin factors of expertise and specialization. Agencies frequently develop expertise in the particular area under consideration that is not available to generalist courts.

Professor Asimow warns, however, that "[i]t is not easy to distinguish application questions from pure questions of law." Id. at 1223 .

440. Balt. Gas \& Elec. Co. v. Natural Res. Def. Council, Inc., 462 U.S. 87, 103 (1983).

441. See infra note 464 and accompanying text.

442. Deference is not, of course, the same thing as abdication of the judicial review function. Even under deferential review, courts are obliged to reverse arbitrary or unsupported agency determinations. See supra note 436 and accompanying text. 
The Kansas courts' interpretations of the judicial review statute are consistent with affording deferential review to these aspects of KDHE's decision. They have stated, for example, that in an appeal of an administrative adjudication, the court should not "try the case de novo [or] substitute its judgment" for that of the agency. ${ }^{443}$ Courts inquiring whether an agency's factual determinations are supported by substantial evidence "may not reweigh the facts, try the case de novo, or substitute their own judgment even if they would have found differently." 444 Indeed, the Kansas Supreme Court has warned that in this context "the courts are not concerned with evidence contrary to the agency findings but must focus solely on evidence in support of the findings." $" 445$ Accordingly, as long as the administrative record contains evidence that supports KDHE's determinations, a reviewing court must uphold those determinations, even if the record also contains evidence to the contrary.

\section{Judicial Interpretation of Substantial Endangerment and Similar Provisions}

This article is not the place to undertake a thorough review of the administrative record upon which KDHE based its denial of the Sunflower permit application. The Kansas appellate courts have not previously reviewed KDHE's application of section 65-3012 in any reported decision, so there is little directly applicable precedent to serve as guidance for how the Kansas Supreme Court will approach the task of reviewing KDHE's substantial endangerment finding. Judicial interpretation of the application of analogous provisions under the federal pollution control laws may provide some guidance, however. The Tenth Circuit has held, for example, that a finding of endangerment does not require proof of actual harm to health or the environment. ${ }^{446}$ Instead, a showing of threatened or potential harm-of risk-is sufficient. ${ }^{447}$ The same court has ruled that an endangerment qualifies as

443. Peterson v. Kan. Dep't of Health \& Env't, 59 P.3d 6, 9-10 (Kan. Ct. App. 2002).

444. Blue Cross \& Blue Shield of Kan., Inc. v. Praeger, 75 P.3d 226, 246 (Kan. 2003).

445. Id. (emphasis added, citation omitted); see also Graham v. Dokter Trucking Group, 161 P.3d 695, 700 (Kan. 2007) (citation omitted) (stating that under substantial evidence review of agency determinations, "[w]e review the evidence in the light most favorable to the prevailing party and do not reweigh competing evidence or assess credibility of witnesses"); In re Amoco Prod. Co., 102 P.3d 1176, 1184 (Kan. Ct. App. 2004) (stating that "this court will uphold findings supported by substantial evidence even if the record could have also supported contrary findings").

446. Burlington N. \& Santa Fe Ry. Co. v. Grant, 505 F.3d 1013, 1020 (10th Cir. 2007).

447. Id.; Price v. U.S. Navy, 39 F.3d 1011, 1019 (9th Cir. 1994) (citation omitted) (“Courts have also consistently held that 'endangerment' means a threatened or potential harm and does not require proof of actual harm.”). 
"substantial" when it is "serious," or when "there is reasonable cause for concern that someone or something may be exposed to risk of harm by [the targeted activities] in the event remedial action is not taken," even if the endangerment is not quantified. ${ }^{448}$ One federal district court agreed with the proposition that "courts... have had very little difficulty finding that such an endangerment exists since the standard necessary to establish an imminent and substantial endangerment is minimal." "449 If the Kansas Supreme Court follows these precedents, the fact that "[w]e don't have any problems... with clean air here" 450 in terms of demonstrated, actual harm that has already occurred, or a quantified determination of the harm that climate change will cause in Kansas in the future should not preclude it from affirming KDHE's determination that the contribution of the Holcomb units to climate change present a substantial endangerment.

A decision by the South Dakota Supreme Court in early 2008 may provide some insights into the fate of a challenge to KDHE's substantial endangerment findings with respect to the Holcomb units. Otter Tail Power Company applied to South Dakota Public Utilities Commission ("SDPUC") for permission to construct a 600 megawatt coal-fired electric generating plant that would emit 4.7 million tons of $\mathrm{CO}_{2}$ each year. ${ }^{451}$ A state statute requires a permit applicant to show that the proposed facility "will not pose a serious threat of injury to the environment" or to social and economic conditions in the siting area and that the facility "will not substantially impair the health, safety or welfare" of the inhabitants of that area. ${ }^{452}$ Several non-profit environmental organizations opposed the plant, claiming that the $\mathrm{CO}_{2}$ emissions would contribute to global warming and pose a threat of serious injury. ${ }^{453}$ The SDPUC issued the permit, finding that the proposed plant would produce eighteen percent less $\mathrm{CO}_{2}$ than other existing coal-fired plants as a result of the efficiency of the super-critical boiler technology it would use. ${ }^{454}$ In addition, the agency concluded that

448. Grant, 505 F.3d at 1020 (citing Interfaith Cmty. Org. v. Honeywell Int'l, Inc., 399 F.3d 248, 259 (3d Cir. 2005); Parker v. Scrap Metal Processors, Inc., 386 F.3d 993, 1015 (11th Cir. 2004)).

449. United States v. Alcoa, Inc., 98 F. Supp. 2d 1031, 1035 n.3 (N.D. Ind. 2000) (citation omitted). As noted above, section 65-3012(a) does not even require that the endangerment be imminent to trigger KDHE's regulatory authority. See supra notes 351-53 and accompanying text.

450. See supra note 274 .

451. In re Otter Tail Power Co., 744 N.W.2d 594, 597-98 (S.D. 2008).

452. Id. at 597 (citing S.D. CoDIFIED LAWS $§ 49-41 \mathrm{~B}-22$ ).

453. Id. at 596,599 .

454. Id. at 602 . 
the plant would not contribute materially to the production of anthropogenic $\mathrm{CO}_{2}$ because it would increase U.S. emissions of $\mathrm{CO}_{2}$ by only about seven-hundredths of one percent. ${ }^{455}$ Based on these factors, the SDPUC concluded that the utility had carried its burden of showing that the proposed plant would " not pose a threat of serious injury to the environment." $" 456$

The environmental groups appealed the decision, but the state supreme court upheld the issuance of the permit. After reviewing the "voluminous" administrative record as a whole, including expert testimony proffered by both the environmental groups and the utility, ${ }^{457}$ the court held that the SDPUC's decision reflected neither a clear error of judgment nor a conclusion unsupported by the law. ${ }^{458}$ It characterized global warming as "a momentous and complex threat to our planet," but asserted that the social, economic, and environmental consequences of climate change "implicate policy decisions constitutionally reserved for the executive and legislative branches." 459 In light of the failure of "our political leaders" to issue emission standards for $\mathrm{CO}_{2}$, the court chose to "refrain from settling policy questions more properly left for the Governor, the Legislature, and Congress. No matter how grave [the court's] concerns on global warming, [it] cannot allow [its] personal views to impair [its] role under the Constitution." 460 The court noted that the South Dakota legislature had designated the SDPUC as the agency responsible for ruling on air quality permits for electric utilities. The court was obliged to uphold the agency's determination unless it was clearly erroneous in light of the entire record, arbitrary and capricious, or an abuse of discretion. ${ }^{461}$ The court found the SDPUC's decision that the plant would not pose a threat of serious injury to the environment to be well-reasoned and informed. It refused to upset that determination, given the legislature's decision to vest that "judgment call" in the agency. ${ }^{462}$

The statutory standard governing the SDPUC's decision (whether the proposed plant "will pose a threat of serious injury to the environment") is similar to the standard at issue in the Sunflower case (whether "the emission of air pollution presents a substantial endangerment to the

455. Id.

456. Id. (quoting S.D. CoDIFIED LAWs $\S 49-41 B-22)$.

457. The record contained more than 1400 pages of documentary evidence. Id. at 603 .

458. Id. at 603-04.

459. Id. at 603 .

460. Id.

461. Id. (citing Korzan v. Mitchell, 708 N.W.2d 683, 686 (S.D. 2006)

462. Id. at 604 . 
health of persons or to the environment"). The Holcomb units would have emitted twice the amount of $\mathrm{CO}_{2}$ as the Otter Tail plant, but the percentage of total U.S. $\mathrm{CO}_{2}$ emissions for which the Holcomb units would have been responsible would still have been relatively low. Faced with the Holcomb facts, the SDPUC might have come out the same way as it did in the Otter Tail case.

KDHE, however, came out the other way. The question is whether the Kansas Supreme Court is likely to reverse that determination. The SDPUC decision approving the Otter Tail permit was thirty-four pages long, ${ }^{463}$ considerably more extensive than Secretary Bremby's decision. The entire SDPUC decision was not devoted to a discussion of the global warming issue, however. Further, the thirty-four page decision was but part of the enormous administrative record compiled during the proceeding. The same is true of Bremby's decision. In testimony before the Kansas legislature, Bremby listed some of the sources on which he relied in denying Sunflower's permit application. These include the U.S. Supreme Court's decision in Massachusetts v. EPA, the Kansas Attorney General's opinion, the reports of the IPCC on climate change, and "the extensive administrative record-including comments submitted at the public hearings held in regard to the Sunflower Electric permit application." 464 A close analysis of the two administrative records would be needed to ascertain whether one provides more compelling evidence of a threat to health and the environment from the proposed plants' $\mathrm{CO}_{2}$ emissions than the other. As indicated above, however, only the evidence that supports Bremby's determination is relevant. ${ }^{465}$

One important difference between the two decisions relates to the relationships among the relevant branches of government. The contexts in which the two cases proceeded to court were completely different. The SDPUC ruled in favor of the utility, while KDHE ruled against it. Assuming that KDHE acted within the scope of its statutory authority, ${ }^{466}$ the Sunflower case, unlike Otter Tail, is not one in which "our political leaders" have said or done nothing to restrict activities that contribute to climate change. If $\mathrm{KDHE}$ has the authority to deny a permit despite the fact that threatening activity has not yet begun and $\mathrm{CO}_{2}$ is not currently regulated by EPA or KDHE, then the policy decisions reflected in KDHE's denial of the Sunflower application have been resolved (or at least authorized) by both of the political branches of government.

463. Id.

464. Bremby Testimony, supra note 263 , at $2-3$.

465. See supra note 445 and accompanying text.

466. The statutory authority issues are addressed in Part IV.A. 
Accordingly, the same separation of powers concerns that impelled the South Dakota Supreme Court to refrain from reversing the agency's decision to approve the permit should give pause to the Kansas courts as they consider whether to reverse KDHE's denial of the permit. Those courts may or may not conclude that KDHE's decision is supported by substantial evidence in the record. The threat of judicial usurpation of the policymaking authority of the political branches that was central to the Otter Tail decision, however, lies more in overturning than in upholding KDHE's decision.

\section{THE Future OF COAL-Fired POWER IN KANSAS IN THE Climate CHANGE ERA}

The impact of KDHE's denial of the Sunflower permits will depend most immediately on efforts to reverse the decision, either administratively or in post-2008 legislative sessions. ${ }^{467}$ Even assuming the decision stands, its impact on the future of coal-fired power production in Kansas is unclear. Air permits for coal-fired power plants in Kansas must be renewed every five years. ${ }^{468}$ By the end of 2008 , sixteen coal-fired power plants in the state face permit renewal proceedings. State legislators and business leaders expressed concern over the fate of those applications based on the Sunflower precedent. ${ }^{469}$ Senate Utilities Committee Chairman Jay Emler stated, for example, that "[b]ased upon a rather nebulous finding of fact that $\mathrm{CO}_{2}$ is hazardous to the public health, I would think that would put every application for renewal in jeopardy." ${ }^{470}$ Secretary Bremby seemed to indicate, however, that he would distinguish between renewal of existing plant permits and authorization of a large new source of GHGs. ${ }^{471}$ A decision by KDHE not to extend the Sunflower precedent to permit renewals for existing coal-fired plants might create the perception that Sunflower was treated unfairly, ${ }^{472}$ especially because, according to some observers, it would

467. See supra notes 296-305 and accompanying text for discussion of the efforts in the 2008 legislative session to reverse Secretary Bremby's decision.

468. KAN. AdMIN. REGS. § 28-19-514(a) (2006).

469. Cf. Mark Fagan, Leader: Coal Ruling Hurts Economy, LAWRENCE J.-WORLD, Jan. 9, 2008, http://www2.ljworld.com/news/2008/jan/09/leader_coal_ruling_hurts_economy/_discussing economic concerns regarding the Holcomb decision).

470. Associated Press, KDHE to Review Permits for 16 Coal Plants, Wichita Eagle, Nov. 11, 2007 , at $7 \mathrm{~B}$.

471. See id.; Associated Press, Legislators Limited in Fighting Coal Ruling, Wichita EAGLE, Nov. 13, 2007, at 3B.

472. The same argument was made by attorneys for the utility seeking to build a new coal-fired power plant near Great Falls, Montana. See Karl Puckett, Opponents of Coal Plant Seek $\mathrm{CO}_{2}$ 
have been a more efficient operation than some existing plants dating back to the 1950 s. ${ }^{473}$

Regardless of the fate of the Holcomb units and the existing coalfired plants, the larger question is whether Kansas takes steps to increase the contribution of cleaner fuels, such as renewable sources, to the state's energy mix and otherwise to reduce the state's reliance on fossil fuelbased energy. In early 2008, Governor Sebelius issued an executive order creating the Kansas Wind Working Group. ${ }^{474}$ The order states that Kansas "has an abundant supply of wind," "is invested in making renewable energy sources an integral part of the states' energy use portfolio," and "is committed to developing an effective and progressive plan to utilize our natural resources for renewable energy to their fullest potential." ${ }^{\text {"475 }}$ The Governor charged the Group with initiating, acting upon, and considering all necessary strategies to optimize wind energy utilization in Kansas; developing professional and information-sharing networks for wind energy stakeholders; promoting Kansas as a leader in the development of wind energy resources; and assisting in the development, coordination, and execution of the state's future wind energy policies. ${ }^{476}$ The strategy seems to play to the state's strengths. The state may lack the natural resources that allow regions like the

Limitations, GREAT FALlS TRIB., Dec. 22, 2007, at 1A (stating that utility attorneys argued that it would be unfair to apply rules not already in place when the application was filed, even though they are likely to be adopted in the future). The state environmental agency refused to impose $\mathrm{CO}_{2}$ emission controls on the plant, concluding that it lacked the authority to regulate $\mathrm{CO}_{2}$ emissions, and the state environmental review board affirmed that decision. See supra note 381.

473. KDHE to Review Permits for 16 Coal Plants, supra note 470, at 7B. Sunflower has asserted that the permit denial violated its equal protection rights under the federal and state constitutions because it prohibits the plants' potential $\mathrm{CO}_{2}$ emissions even though "those emissions are much less than aggregate $\left[\mathrm{CO}_{2}\right]$ emissions from existing permitted sources and from newly permitted sources in Kansas." Petition for Judicial Review of KDHE Denial of Permit Application Under K.S.A. § 65-3012(a), supra note 306, at 11. See also Petition for Review of KDHE Denial of Permit Application Under K.S.A. § 65-3008a(b), supra note 308, at 10. The merit of this equal protection challenge is beyond the scope of this article.

474. Kan. Executive Order 08-01 (Jan. 7, 2008), http://www.governor.ks.gov/executive/ Orders/exec order0801.htm.

475. Id.

476. Id. § 5. Shortly before the Governor issued the order, the Kansas Corporation Commission found a utility's plans to own 149 megawatts of wind generation and to enter into purchased power agreements to purchase an additional 146 megawatts of wind generation to be prudent. At the same time, however, the Commission refused to approve the utility's request for an additional one percent rate of return on its wind-related investments. It found that the uncertainties inherent in wind generation did not justify allocating to ratepayers the cost of the additional return sought. In re Petition of Westar Energy, Inc., Docket No. 08-WSEE-309-PRE (Kan. Corp. Comm'n Dec. 27, 2007) (final order), available at http://www.kcc.state.ks.us/docket/cal.cgi?docket=08-WSEE-309PRE. In the wake of the decision, Westar Energy announced it was postponing plans to secure an additional 200 megawatts of wind energy. See Scott Rothschild, Sebelius Creates Wind Energy Group, LAWRENCE J.-WORLD, Jan. 8, 2008, http://www2.ljworld.com/news/2008/jan/08/ sebelius_creates_wind_energy_group/. 
Pacific Northwest to rely heavily on non-carbon sources such as hydropower facilities, but it has wind aplenty. ${ }^{477}$

Another alternative to coal-fired power production is nuclear power. Increasing concerns over global climate change have sparked renewed interest in the moribund nuclear power industry, not only in the United States ${ }^{478}$ but also in Europe. ${ }^{479}$ The national security concerns that accompany the management and use of nuclear fuel, the lingering memories of the Three-Mile Island accident, ${ }^{480}$ and the absence of a permanent solution to the problem of spent fuel and other high-level radioactive waste disposal, ${ }^{481}$ however, continue to make the nuclear power option a divisive one. It is not hard to imagine concrete plans to pursue a nuclear power project in Kansas leading to a repeat of the controversy surrounding construction, licensing, and ratemaking approval of the Wolf Creek plant in Burlington, Kansas in the early 1980 s. $^{482}$

Still another option, at least in the short run, would be for Kansas utilities to purchase some of their power from utilities in other states. After KDHE denied Sunflower's permit for the Holcomb units, it began pursuing the possibility of purchasing 125 megawatts of power from a

477. For a map of ongoing and proposed wind energy projects in Kansas, see Kansas Energy Information Network, Kansas Wind Energy, http://www.kansasenergy.org/wind_projects.htm (click on Map of Existing and Proposed Wind Projects in Kansas). See also U.S. Dep't of Energy, Energy Efficiency and Renewable Energy, Wind Powering America, Kansas Wind Activities, http://www. eere.energy.gov/windandhydro/windpoweringamerica/astate_template.asp?stateab=ks.

478. Professor Joe Tomain has described the changed atmosphere as follows:

Global warming has revived interest in nuclear power. How much interest remains to be seen. Still, the most significant statement that can be made about nuclear power is that this energy source is on the table for discussion more than it has been for over 25 years, because of the environmental degradation caused by burning fossil fuels. Traditional nuclear industry and trade association interests have taken advantage of this phenomenon to continue to advocate their Promotional Policy regarding nuclear power. Nuclear agnostics have added this issue to their own future energy policies because it is an attractive alternative to oil and other fossil fuels, which, in addition to their role in climate change, are becoming more difficult to find and secure and, therefore, higher priced.

Joseph P. Tomain, Nuclear Futures, 15 Duke EnVTL. L. \& PoL'Y F. 221, 249 (2005).

479. See, e.g., Peter D. Cameron, The Revival of Nuclear Power: An Analysis of the Legal Implications, 19 J. ENVTL. L. 71 (2007).

480. See generally Eric R. Pogue, The Catastrophe Model of Risk Regulation and the Regulatory Legacy of Three-Mile Island and Love Canal, 15 PENN ST. ENVTL. L. REV. 463 (2007).

481. See Karl S. Coplan, The Intercivilizational Inequities of Nuclear Power Weighed Against the Intergenerational Inequities of Carbon Based Energy, 17 FORDHAM ENVTL. L. REV. 227, 23343 (2006); James E. Hickey, Jr., Reviving the Nuclear Power Option in the United States: Using Domestic Energy Law to Cure Two Perceptions of International Law Illegality, 35 HOFSTRA L. REV. 425, 434 (2006).

482. See generally Symposium on Regulation of the Wolf Creek Nuclear Power Plant, 33 U. KAN. L. REV. 419, 419-524 (1985). 
proposed new coal-fired plant near Norborne, Missouri. ${ }^{483}$ That option might shift some of the conventional pollution (such as $\mathrm{SO}_{2}$ emissions) generated by coal-fired plants from Kansas to Missouri and states to the east, but it would have no impact on minimizing the contribution of Kansas power consumption to GHG emissions that contribute to climate change.

Coal-fired power production could receive a boost if technologies are developed to reduce the degree to which the use of coal to produce energy generates GHGs or to effectively sequester whatever carbon emissions are produced. ${ }^{484}$ In the absence of such proven technologies, the fate of coal-fired power production, in Kansas and elsewhere, is uncertain. The KDHE's decision to deny an air quality permit for the proposed Holcomb units is both a product of that uncertainty and a contributing factor to future uncertainty over the role of coal in generating electricity. The decision to deny the permits certainly created a furor. It may or may not further an optimal mix of energy or economic policies for the state. This article demonstrates, however, that it is far from a radical decision, when viewed in the context of what other states are doing to deal with the environmental risks created by coal-fired power production. Instead, it is fully consistent with a nationwide trend toward reduced reliance on coal-fired power that includes the development of renewable portfolio standards in many states, the imposition of restrictions on GHG emissions both by individual states and regional organizations, and the denial of individual permits in at least three states in 2007 alone. ${ }^{485}$ That trend has been facilitated by the support of groups not traditionally known for their concern over the effects of industrial pollution, such as ranchers concerned about the impact of climate change on the availability of water they need to support their livestock. ${ }^{486}$

483. Utility Eyes Proposed Mo. Power Plant, LAwrenCE J.-WorLD, Jan. 19, 2008, at 3B

484. Coal producing states have a strong interest in the development of effective sequestration technology and some of them are staking out positions as leaders in that process. See, e.g., Bob Moen, Panel Backs Carbon Storage Regulation, CASPER STAR TRIB., Jan. 24, 2008, available at http://www.casperstartribune.net/articles/2008/01/24/news/wyoming (describing Wyoming governor's position that carbon capture and sequestration is vital to the state's economy). For a discussion of carbon sequestration technology, see Leslie R. Dubois, Comment, Curiosity and Carbon: Examining the Future of Carbon Sequestration and the Accompanying Jurisdictional Issues as Outlined in the Indian Energy Title of the 2005 Energy Policy Act, 27 ENERGY L.J. 603 (2006).

485. Even in Montana, where the state BER in early 2008 approved the state DEQ's omission of $\mathrm{CO}_{2}$ controls from a permit issued to a proposed new coal-fired power plant, Board members recognized the need to address climate change, anticipated regulation of $\mathrm{GHG}$ emissions from power plants in the near future, and bemoaned the lack of authority to regulate $\mathrm{CO}_{2}$ emissions under current state law. See Dennison, supra note 112.

486. See Editorial, Montana and Kansas Take on Big Coal, N.Y. TimES, Oct. 23, 2007. 
There is little question that KDHE's denial of the Holcomb air quality permit on the basis of the plants' potential to contribute to climate change was unprecedented in Kansas. It is also legitimate to question the agency's authority to issue that decision in light of the absence of judicial interpretation of the applicable statutes. Nevertheless, there are strong arguments to support the conclusion that KDHE had ample authority to do exactly what it did. If the text of the state's air quality statute does not dictate the conclusion that KDHE acted within the scope of its authority in denying the Sunflower permit application, the statute certainly is reasonably interpreted to support that conclusion. KDHE's interpretation and application of the statute are also consistent with the policies underlying precautionary environmental legislation such as the Kansas substantial endangerment provision. Finally, the deference typically afforded agency policy determinations of the sort involved here makes it very difficult to characterize KDHE's action as an illegitimate "administrative fiat" that somehow threatens the legislature's primacy in fashioning energy, environmental, and economic policy for the state. 